\title{
Motor aspects of binocularity
}

Citation for published version (APA):

Bosman, J. (2001). Motor aspects of binocularity. [Doctoral Thesis, Maastricht University]. Datawyse / Universitaire Pers Maastricht. https://doi.org/10.26481/dis.20011212jb

Document status and date:

Published: 01/01/2001

DOI:

10.26481/dis.20011212jb

Document Version:

Publisher's PDF, also known as Version of record

\section{Please check the document version of this publication:}

- A submitted manuscript is the version of the article upon submission and before peer-review. There can be important differences between the submitted version and the official published version of record.

People interested in the research are advised to contact the author for the final version of the publication, or visit the DOI to the publisher's website.

- The final author version and the galley proof are versions of the publication after peer review.

- The final published version features the final layout of the paper including the volume, issue and page numbers.

Link to publication

\footnotetext{
General rights rights.

- You may freely distribute the URL identifying the publication in the public portal. please follow below link for the End User Agreement:

www.umlib.nl/taverne-license

Take down policy

If you believe that this document breaches copyright please contact us at:

repository@maastrichtuniversity.nl

providing details and we will investigate your claim.
}

Copyright and moral rights for the publications made accessible in the public portal are retained by the authors and/or other copyright owners and it is a condition of accessing publications that users recognise and abide by the legal requirements associated with these

- Users may download and print one copy of any publication from the public portal for the purpose of private study or research.

- You may not further distribute the material or use it for any profit-making activity or commercial gain

If the publication is distributed under the terms of Article $25 \mathrm{fa}$ of the Dutch Copyright Act, indicated by the "Taverne" license above, 
Motor aspects of binocularity 
J.Bosman, Maastricht 2001

Universitaire Pers Maastricht

ISBN 9052783349 


\title{
Motor aspects of binocularity
}

\author{
PROEFSCHRIFT \\ ter verkrijging van de graad van doctor aan \\ de Universiteit Maastricht,
}

op gezag van de Rector Magnificus, Prof. Dr. A.C. Nieuwenhuilzen Kruseman

volgens het besluit van het College van Decanen, in het openbaar te verdedigen

op woensdag 12 december 2001 om 12.00 uur

door

Jeroen Bosman

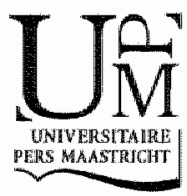




\section{Promotores:}

Prof.dr. H. Kingma

Prof.dr. J.J. Manni

Prof.dr. J. Troost

\section{Co-promotor:}

Dr. M.P.M. ten Tusscher (Laurentiusziekenhuis, Roermond)

Beoordelingscommissie:

Prof.dr. J.S.H. Vles (voorzitter)

Prof.dr.ir. T. Arts (Technische Universiteit Eindhoven)

Dr. J. van Opstal (Katholieke Universiteit Nijmegen)

Prof.dr. H. Simonsz (Erasmus Universiteit Rotterdam)

Prof.dr. H. Steinbusch

The publication of this thesis was financially sponsored by:

Skalar Medical BV and Bausch \& Lomb 
"Can you do addition?" the White Queen asked. "What's one and one and one and one and one and one and one and one and one and one?" "I don't know," said Alice. "I lost count."

Lewis Carroll, Through the Looking Glass. 



\section{Contents}

Contents

Chapter 1

General introduction to eye movements.

Chapter 2

The Influence of Visual Input on the Gain of the Vestibulo- Ocular Reflex.

Chapter3

Three Dimensional Eye Movements during Horizontal Smooth Pursuit in Patients with Micro-strabismus and/or Amblyopia.

Chapter 4

Listing's Law in Strabismus and Amblyopia.

\section{Chapter 5}

The Influence of Eye Muscle Surgery on Shape and Relative Orientation of

Displacement Planes: Indirect Evidence for Neural Control of 3D-Eye Movements.

Chapter 6

A binocular 2D-video eye tracker for babies using the corneal reflection-centre of pupil technique.

\section{Chapter 7}

Summary.

Chapteir 8

Samenwatting. 


\section{Chapter}

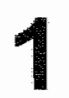

General introduction to eye movements. 
In this chapter, a basilc overview of binocular eye movements will be given. Each following chapter conteitins a more detafled introduction. 


\subsection{Eye movements.}

The study of eye movements originates at leasi from the fifh century $\mathrm{BC}$. Greek philosophers in this time period observed, that humans point their eyes at an object, in order to see it. It was believed that a person could see by means of liglt particles that leave the eye in form of a cone of straight rays with its base in the pupil. Although this assumption was incorrect, the coupling between vision and eye movements was quite accurate. Centuries later, around 1000 $\mathrm{AD}$, Alhazen (965-1040 AD) was the first to describe the principle of vision: light travels from an object through the pupil into the eye, where a lens focuses the image on the retina (Howard and Rogers 1995). Today we know, that in order to see an object optimally, we have to point our eyes in such a way that the image of an object falls centrally on the foved. The fovea is a small area in the retina subtending only 0.5 degrees of aro and is specialized for discrinumation of visual detail (Carpenter 1988). Visual acuty is highest when the image is kept steady on the fovea, images moving at velocities as low as 2.5 degrees per second ("slip") can degrade visual acuity (Westheimer and McKee 1975). In real life, this is not as easy as it may appear due to movement of the subject, of the target or of both. In humans, several classes of eye movements to optimize vision have developed: vesibulo-ocular reflex. oprokinetic reflex. saccades, smooth pursuir and vergence (Leigh and Zee 1983). Fach of these classes will be described shortly.

Since our eyes are fixed in our head, every movement of our head results in movement of the image of an object on the retina. To cancel out this effect, humans generate compensatory eye movements: during a horizontal head movement to the right, moving the eyes to the left eliminates the movement of the image on the retina. During fast head movements, at frequencies larger than $\pm 2 \mathrm{~Hz}$ (Kasteel-van Linge and Maas, 1990), the visual system is not able to act rapidly enough to produce compensatory eye movements since the visual system generally is a fairly slow system: retinal image processing takes about $70 \mathrm{msec}$. The vestibulo-ocular reflex, which depends upon the motion sensors (accelerometers) of the labyrinthine semicircular canals, is considerably faster than the visual system (Robinson 1968) and can hold images of the seen world steady on the retina during fast angular accelerations of the head (in the range of $0.1-10 \mathrm{~Hz}$, from Carpenter, 1988). However, during prolonged rotations the eye obviously cannot go on turning indefinitely in the orbit. In fact, the compensatory eye movements are periodically interrupted by fast flicks in the direction of rotation, which thus enable the aye to continue its task of matching velocity. A graph of the deviation of the eye versus time during such a rotation has a characteristic sawlooth appearance, consisting of a slow phase in the compensatory direction and a quick platse in the anticompensatory direction. This whole patten is known as miskrymus.

Movement of the visual scene across the field of view evokes an involunary to-and-fro movement of the eyes known as optokinetic nystagmus. Slow phases, with approximately the same velocity as the moving visual scene, are interspersed with saccadic movements in the opposite direction (fast phases). The movements of the visual scene can be the result of a projection (Purkinje 1825) or the result of slow and sustained movements of the head at constant velocity (from Sharpe 1993). For instance, if we look at the eyes of a person looking out of the window of a moving train, we can see that his or her eyes tend to follow the objects passing by onto the point the eyes reach their maximum left or right position. At this moment the eye makes a quick step in the opposite direction, after which the movement repeats.

In foveal vision, it became necessary to change the line of sight independent of head movements. This way, images of interest could be placed or kept on that part of the retinat, where visual acuity is best: the fovea (Leigh and Zee 1983). The saccadic system enables the 
eyes to "jump" from target to target. The velocity of a saccade can reach up to 1000 degrees per second (Carpenter 1988). Saccades can be divided in wo groups: voluntary and involuntary saccades. Voluntary saccades occur when a subject shifts his aitention from one target to another. Involuntary saccades occur during quick phases of the $\mathrm{OKN}$ or they can be triggered by a sound (e.g. when someone standing next to you claps in his hands) or when an object appears in the periphery of the retina.

When the eyes track a small moving target, they do it partly by making saccades that bring the fovea on to the target, and partly by slower, continuous movements whose welocity is closely related to that of the target (Carpenter 1988). This second motion is called smoom purswi.

With the development of frontal vision and binocular vision (see 1.5) it has become possible to direct both fovea at one object of interest. In order to direct the fovea of both eyes on the same object, disconjugate or vergence eye movements are essential. If the image of an object that is near the eyes is to be brought to the fovea of each retina, it is clear that the line of sight of the two eyes must be brought to converge from the parallelity they assume for very distant objects. Vergence movements are generally slow (Westheimer and Mitchell 1956) and abnomalities of this system are responsible for a considerable portion of ocular motos" diseases (Leigh and Zee 1983 and Carpenter 1988).

\subsection{Gross anatomy of eye muscles.}

In the previous paragraph various types of eye movements humans perform to optimize vision were described. This paragraph roughly describes the muscles we use for these tasks. Three pairs of muscles rotate the eyeball in all directions: the medial and lateral rectus, the superior and infertor recrus and the superior and inferior oblique museles (figure 1.1).
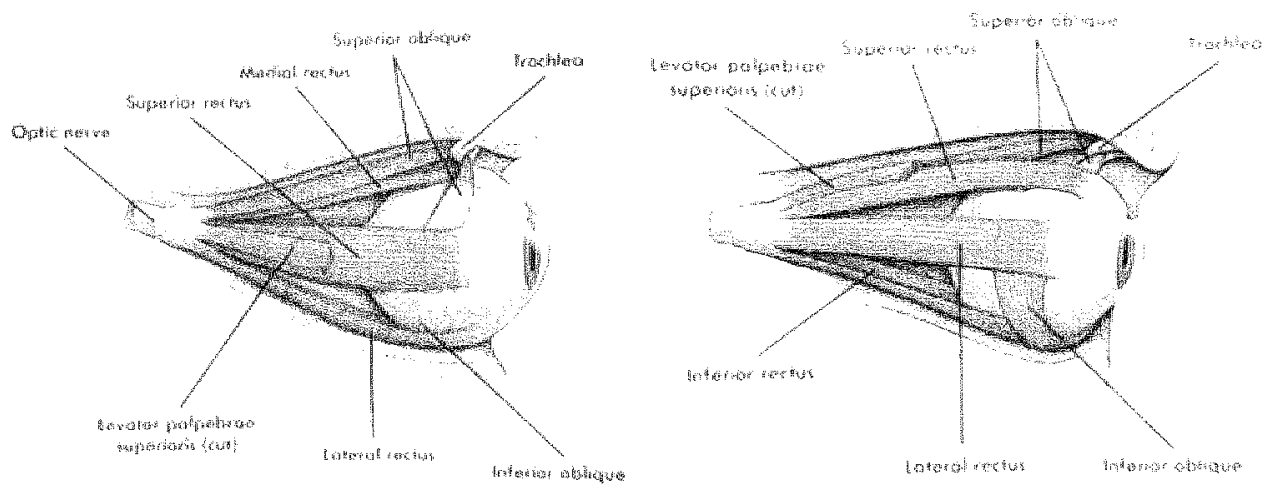

Figure 1.1. The extraocular muscles of the human right eye (from Lindsay 1996).

The superior oblique muscle takes its origin at the back of the orbit near the origin of the rectus muscles and inserts behind the insertion of the superior rectus. From this location the superior oblique would rotate the eyeball upward, if it were not for the trochlea that diverts the muscle medially together with an intorsional component. No trochlea assists the inferior oblique muscle, however. It reaches under the eyeball from the orbital surface of the superior maxilla (bone of the upper yaw) and inserts behind the insertion of the lateral rectus, where it rotates the eyeball laterally in the opposite direction from the superior oblique. The recti muscles pull from very different directions than the obliques. The recti insert on their 
respective sides of the eyeball and pull directly toward the back of the orbit, where their origins arise from a fibrous ring (awwh of Ziwn) around the optic nerve (Lindsay 1996).

Each orientation of the eye therefore is controlled by the activity of the extra-ocular muscles. As a result each combination of horizontal and vertical eye positions could be associtted with infinitely many torsional positions (van den Berg 1995). Is this what happens in real-life? And why is accurate positioning of both eyes in three dimensions so impontant? To answer these questions we first need to look into the description of three-dimensional cye rotations.

\subsection{Kinematics of eye rotations.}

If we want to be able to study the way in which we move our eyes, we first need an appropriate coordinate system to describe eye orientations. If we regard the center of the eye as fixed in space (or in the head), a combination of horizontal and vertical rotations of the eye uniquely characterizes the direction of the line of sight, but it does not completely detemine the three-dimensional eye position. The rotation about the line of sight is still unspecified. So a third rotation about the line of sight is necessary to describe the eye position completely. If we describe eye rotations by three rotations, a horizontal, vertical around a point in the center of the eyeball and a rotation around the line of sight, we will see that the system does not commute: the sequence of rotations involved detemine the final orientation of the eye. Figure 1.2 shows two sequences of horizontal and vertical eye movements.
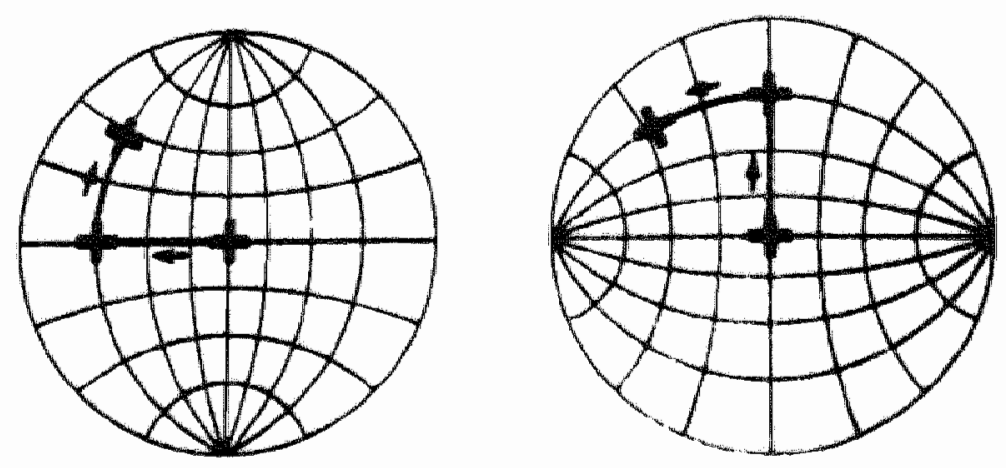

Figure 1.2. Eye movenents in stereographic projection. A) fick s system B) Helmholz's system (from Carpenter 1988).

The first picture shows a horizontal rotation followed by a vertical rotation (this is called a system according to Fick). The cross is now slightly rotated clockwise about the line of sight. If we use a Helmholtz comordinate system, we lirst make a vertical rotation followed by a horizontal rotation. Now the cross is rotated counter-clockwise. Thus the orientation of the cross clearly depends not only on the funal position of the eye at the end of the complete movement, but also on the route by which it got there. 
Another affect of a non-commutative coordinate system is, that if the eye follows this behaviour, after several large gaze shifts the eye would langle up. This can be observed in a simple experment: hold your right arm straight right in front of you. Then move your arm horizontally to the right, followed by an upward rotation. Now your arm is pointing at the ceiling. If you totate your arm to the start position in front of you, you will notice that your arm is rotated 90 degrees. It is impossible to repeat this sequence of movements indefinitely, becatse your arm will "tangle up". The same principle would apply to your eye. Already in 1846, F.C.Donders discovered that the human eye does not behave this way. He observed, that the orientation of the eye is unique for every gaze direction, independent of the trajectory the cye followed. More specifically: the amount of ocular torsion is fully specified by the horizontal and vertical components of the gaze direction. This result was named Donders" law. Note, that this law doesin't state whot the three-dimensional orientation of the eye is in each position, only that it is always the same! Because the eyes do not move in the way of a Fick or Helmholtz coordinate system, we need a commutative coordinate system to deseribe three dimensional eye movements: rotation wectors.

A mathematically more efficient way to describe eye movements is through use of a vector. This way of describing a three-dimensional eye position is based on Euler's theorem, which states that for every two orientations of an object, the object can always move from one to the other by a single rotation about a fixed axis (Euler 1775). In other words, instead of describing eye movements as a sequence of rotations about three axes, we use only one rotation from a reference position to the final position about a single axis (see figure 1.3), which is similar to how we move our eyes. A system that uses this principle is called "rotation vectors" (Lagally 1924). In chapter 4.2 .3 a mathematical description of rotation vectors is given.

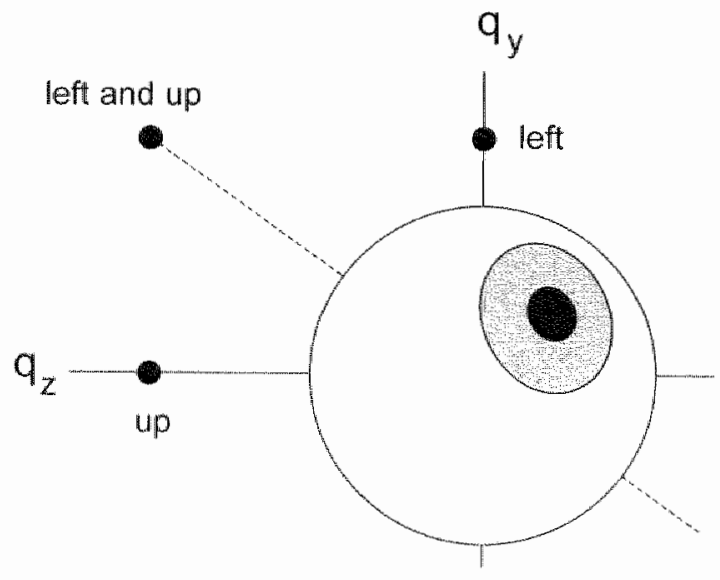

Figure 1.3. Rotafion abour a single axis

Both Ructe (in 1853) and Listing were the first who quantified Donders' Jaw by numerically spectying the amount of torsion of an eye: called Listing 's faw. They stated that all directions of gaze can be reached by rotation about a single axis that is perpendicular to the primary position of gaze (which is approximately straight-ahead). When we use a system of rotation vectors, Listings law has a very simple form: all rotation vectors characterizing eye positions lie closely scattered along a plane. The orientation of this plane, called displacement plane, depends on the orientation of the reference position, which can be chosen arbitrary. If the reference position is orthogonal to the displacement plane, the reference position is called the 
pwimary position and the plane is called Listing is plame (Helmholtz 1863). Note that this law is only valid when the head is in an upright position and the eyes fixate points at optical infinity (no vergence). So what do these laws mean? They reduce the amoun of degrees of freedom of eye movements from three to two (Van Opstal 1998). In the beginning of this paragraph we determined that the orientation of an eyeball could be determined by a horizontal, vertical and torsional orientation (three degrees of freedom). After implementation of Donders" law, under experimental conditions, the torsional orientation is a function of horizontal and vertical eye orientation (two degrees of freedom). If we choose the reference position as the primary position, all eye movements will occur without a change in eye torsion (Listing's law). This can be observed in a schematic representation of Listing ${ }^{2}$ s plane in figure 1.4 .

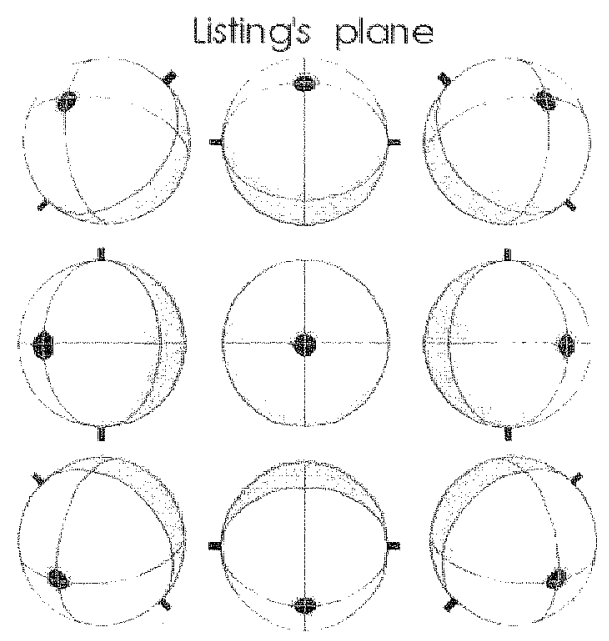

The ed, Catlewa o vilis 1990

Figure 1.4. Lisring 's plane (from Tweed. Cadera et al. 1990).

\subsection{Function and implementation of Listing's law.}

Earlier investigations have shown, that Listing's law holds well for fixations and fairly well during smooth pursuit (e.g. Tweed, Fetter, ef al. 1992) and saccades (Tweed and Vilis 1990). However, the law is violated during the vestibulo-ocular reflex (VOR) (Crawford and Vilis 1991) and during sleep (Nakayama 1975). Two of the most important reasons for Listing's law appear to be: the optimization of ocular motor control (Helmholtz 1863) and assistance of binocular vision (e.g. Minken and van Gisbergen 1996; Tweed 1997 and Kapoula, Bernotas et al.1999). Motor strategy minimizes three dimensional eye eccentricities from a resting position and prevents accumulation of torsion as was mentioned in paragraph 1.3. Binocular vision is assisted, since the relative orientation of images projected on the retina of the two eyes depends on the orientation of both eyes.

But how is Listing"s law implemented? Two hypotheses are followed in the literature: either Listing's law is a consequence of biomechanical properties of the orbita (Schmabolk and Raphan 1994; Demer, Oh ef al. 2000 and Quala and Optican 1998) or it is completely controlled neuronally (Tweed, Fetter, et al. 1992). The main difference between these two approaches is whether positioning of the eyes is controlled netronally in two (horizontal and vertical) or three (horizontal, vertical and torsional) dimensions. The first hypothesis, as 
proposed by Schnabolk and Raphan (1994), states that the brain drives the eyes two dimensionally towad a fixation object, withoul worrying about the torsional orientation of the eyes; torsional positioning of the eyes is thus considered purely a consequence of biomecthanical factors of the orbital plant. In the second hypothesis, the brain controls all eye moventents in three-dimensions (Tweed 1997). In this model the brain controls torsion to both optimize ocular motor control and to assist binocular vision (Minken and van Gisbergen 1996; Tweed 1997 and Kapoula, Bemolas et al. 1999). The oculomotor system appears to weigh both constraints, depending on the situation (Tweed 1997 and Kapoula, Bernotas et al. 1999). This can explain the violation of Listing's law during sleep: in this case binocular vision is obviously not present, therefore the orientation of both eyes does not necessarily need to correspond accurately.

The rellation between control of eye movements and binocular vision is one of the main issues of this thesis. The next paragraph will define the term binocular wision and describe the basic facts necessary for normal bimocular vision.

\subsection{Binocular vision.}

Strictly speaking, all animals with two eyes have binocular vision. But the term binocular wision is usually reserved for those animals that possess a large area of binocular overlap and use it to code depth. In addition, binocular vision provides another advantage: it improves detection by pooling data from both eyes (Jones and Lee 1981).

"The first basic fact of binocular vision is, that both eyes must be capable of seeing and must be capable of simultaneously fixating the same point in space. If one eye has poor or absent vision or if the ability to coondinate the positions of the eyes is compromised, normal binocular vision is not possible. The second basic fact about nomal binocular vision is that it is not possible to see double with corresponding retinal points, as they share a common relative visual direction. If the images falling on corresponding points are similar, they either fuse into a single object or one image is suppressed (monocular vision). If both images are dissimilar either confusion (alternation of the two images in time and space), double vision (diplopia), or suppression (only one of the two images is perceived) occurs. However, stimuli do not need to fall on exactly corresponding retinal points. Each retinal point in one eye is associated with a small area in the other eye, called Panum's area. Because both eyes are separated in space, a slight diference (disparity) in images in both eyes is observed. Disparity beween the positions of stimuli gives additional information about the relative orientation in space. Resulting in the third basic fact for normal binocular vision: information about relative depth can be recovered from binocular disparity. Perception of depth based on the cue of disparity is called stereopsis (Birch 1993).

A controversial, additional cue for depth is the vergence position of the eyes; proprioceptive information of the vergence angle gives us an indication of the distance of an object (Fiorentini, Maffei, ef al. 1985). This is most efficient at fixation distances smaller than 1 meter (Gogle 1962). The vergence angle is approximately zero when the eyes look at an infinite object and increases slowly when the fixation object approaches the subject. When the target becomes close to the subject, e.g. smaller than 1 meter, the change in vergence angle between positions increases, see fugure 1.5 . 


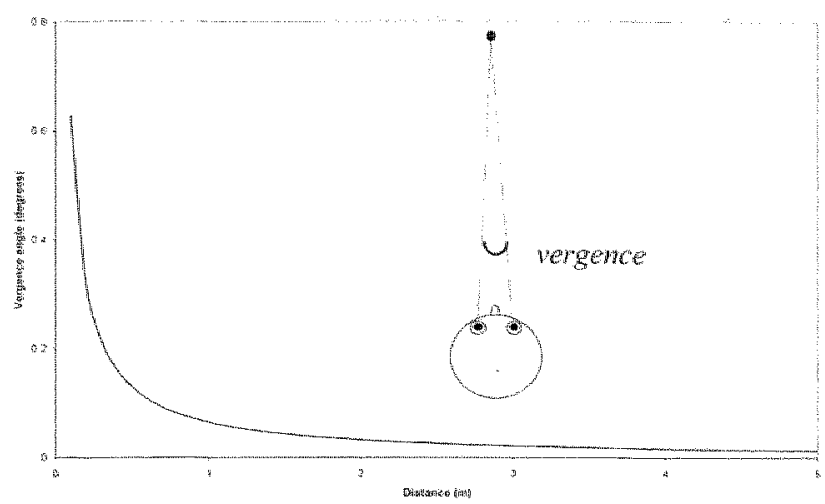

Figure 1.5 Vergence angle versus fixation distance (wih intor-ocular distance of $6.5 \mathrm{~cm}$ ).

The development of binocular vision is not completely understood. The basic pattern for binocular correspondence is laid down before birth. From several experiments (e.g. Slater and Findlay 1975 and Hainline and Riddell 1996) it was shown, that many nomal infants produce appropriate binocular convergence to static targets as early as the first month after birth. However, Horwood (1993) has shown that most babies (88\%) showed some periods of misalignment at some time in the first 6 months, although most lasted only a few seconds and often were related to the infant's attentional state. In this same period babies start to develop binocular fusion. Thorn, Gwiazda et al. (1994) showed evidence for binocular fusion between the twelfth and sixteenth week, and there was a high correlation between the age of onset of convergence and that of binocularity. If accurate binocular control does not develop properly in these first few months until the third year, sensory binocularity (i.e. the ability to fuse images of both eyes) will not develop normally in the infant (Banks, Aslin, et al. 1975) and more elaborately investigated in kittens (e.g. Hubel and Wiesel in 1963, Shlaer in 1971 and Blakemore in 1976).

Ocular dysfunction such as strabismus and amblyopia can start to manifest itself in the first months after birth. If an healthy aduli does not converge both eyes on an object accurately, disparity of the two images will be large and fusion impossible, resulting in diplopia, confusion or suppression. Small infants do not suffer from diplopia or confusion, instead they will suppress the visual information from one eye. If suppression is present for a prolonged time, amblyopia will develop in the infant. A subject who cannot converge on the intended object properly has strabismus. There are many types of strabismus, of which I only will address two. In divergent strabismus, exotropia, the visual axis of none eye is directed outward from the intended point. In convergent strabismus, esotropia, the vistal axe of one eye is directed inward from the intended point.

Amblyopia can also be the result of anisometropia (i.e. unequal refractive error in both eyes) and rarely congenital cataract in early life. Both strabismus and amblyopia have a clear effect on the development of binocular vision depending on the severity. 


\subsection{Goals of this thesis}

All research in this thesis is focused on the first basic necessity of binocular vision: the ability to fixate both eyes on the same point in space both in dynamic and static conditions. Without this ability, normal binocular vision is not possible in human subjects. In normal subjects, the way we move our eyes is elaborately described, although the why and how is still incompletely understood. In this thesis we want to investigate these questions further. More specifically, why and how is Listing"s law implemented in humans. In order to get an answer to these questions, we have setup a series of experiments. In these experiments several subquestions were addressed:

1) How does wisual feedback aid binocular control of eye movements?

2) Do patients with diminished binocular vision move both eyes similar to nomal, healthy subjects?

3) Are torsional eye movements a result of biomechanical properties of muscles in the orbita or is it a reflection of full three dimensional neutonal control?

Chapter 2 looks into the first question. In this chapter we investigate the influence of a change of visual inpul on the vestibulo-ocular refles. In this experiment visual information was suddenly changed, by placing two displacement prisms in front of each eye. The effect of these prisms is, that the subject has to make a vergence eye movement in order to maintain binocular vision. As was mentioned earlier, the vergence angle gives us information about the position of a fixation object relative to the head and could therefore directly influence the gain of the vestibulo-ocular reflex. In this experiment the gain of the vestibulo-ocular reflex should not change, since the distance of the fixation object does not change. We investigate how fast and accurate the visual system operates and if the change in vergence angle affects the gain of the vestibulo-ocular reflex.

Next, we investigate the stability of three-dimensional eye movements during smooth pursuit (Chapter 3) and fixation (Chapter 4 and 5) in normal subjects and in patients with strabismus and/or amblyopia. First a difference in three-dimensional eye movement control between normal subjects and patients is documented during a smooth pursuit eye movement (Chapter 3). Especially the control of binocular torsional eye movements is assessed. Then we investigate the control of three-dimensional eye movement during fixation (Chapter 4). Again a group of nomal subjects and patients with strabismus and/or amblyopia participated. In this chaptat, the validity of Listing's law (question 2) is tested in both groups of subjects.

By introducing a drastic change in biomechanical properties of the eye muscles in the orbita we observed the three-dimensional eye movements of 5 patients with strabismus and/or amblyopia in Chapter 5. Before and after strabismus surgery, Listing's law was tested during fixation. In this chapter we try to answer question 3, whether Listing"s law is a consequence of two-dimensional control of eye positioning, where eye torsion is determined by biomechanical propertics of the orbita or if it is a reflection of full three-dimensional neuronal control.

Since binocular control and binocular vision are developed in the first few months after birth, a device was build to record binocular horizontal and vertical eye movements of babies (Chapter 6). Prescnlly, no accurate and easy to use techniques are available to measure stability of binocular eye movements in babies. The apparatus build, is a video system that uses the brigh pupil - coneat reflex method to record binocular eye movements in a non- 
intrusive way. The accuracy of the system was compared to a simultaneous measurement with scleral search coils in a healthy subject.

\subsection{Literature}

Banks M.S., Aslim R.N. and Letson R.D. (1975) Sensitive period for the development of human binocular vision. Science 190, p. 675.677 .

Van den Berg AV. (1995) Kinematics of eye movement control. Proc. R. Lond.B.Biol.Sci. 260, p. $191-197$.

Birch E. (1993) Introduction. In Early visual development, normal and abnormal. Ed. K. Simons Oxford University Press. New York, Oxford, p.197-200.

Blakemore C. (1976) The conditions required for the mantenance of binocularity in the kitten's wisual cortex. J.Physiol. 261, p. 423-444.

Carpenter R.H.S. (1988) Mowements of the eyes, $2^{\text {nd }}$ edition. Pion Limited London.

Crawford J. D. and Vilis T. (1991) Axes of eye rotation and Listing's law during rotations of the head. J-Neurophysiol. 65, p. 407-23.

Demer J.L., Oh S.Y. and Poukens V. (2000) Evidence for Active Control of Rectus Extraocular Musle Pulleys. Invest. Ophthalmol. Vis. Sci. 41, p. 1280-1290.

Donders F.C. (1846) Physiologische en pathologische aanteekeningen van gemengden aard. IV. De beweegingen van het menselijke oog. Ned. Lancet 2, p.104- 158 .

Euler L. (1775) Formulae generales pro translatione quancunque corporum rigidonum. Commentarii Academiae Scientarum Imperialis Petropolitanae 20, p.189-207.

Ferman L., Collewijn H., Jansen T. C. and Van den Berg A. V. (1987) Human gaze stability in the horizontal, vertical and torsional direction during voluntary head moventents, evaluated with a thee-dimensional scleral induction coil technique. Vision Res. 27, p. 811-28.

Fiorentini A., Maffei L., Cenni M.C. and Tacehi A. (1985) Deaflerentation of oculomotor proprioception affects depth discrimination in cats. Exp. Brain Res. 59, p.296-301.

Gogel W.C. (1962) The effect of convergence on perceived size and distance. I. Psychology 53, p. $475-489$.

Hainline L. and Riddell P.M. (1996) Eye alignement and convergence in young infants. In Infant Vision, Vital-Durand, Atkinson, Braddick (Eds), Oxford Science Publications, p.221247.

Helmholtz H v. (1863) Uber die normalen Bewegungen des menslichen Auges. Graefes Arch. Ophthalmol. 9. p.153-214. 
Horwood A. (1993) Matemal observations of ocular alignment in infants. J. Ped. Ophihalm. and Suab. 30, p. $100-105$.

Howard I.P. and Rogers B.J. (1995) Binocular vision and stereopsis. Oxford Psychology series N0.29, Oxford Unversity Press and Clarendon Press, New York, Oxford.

Mubel D.H. and Wiesel T.N. (1963) Receptive fields of cells in striate cortex of kittens reared with artificial squint. J. Neurophysiol. 30, p.994-1002.

Jones R.K. and Lee D.N. (1981) Why two eyes are better than one: the two wiews of binocular vision. J. Optical Soc. America 37, p.217-263.

Kapoula $Z$, Bernotas $M$ and Haslwanter T. (1999) Listing's plane rotation with convergence: role of disparity, accommodation, and depth perception. Exp.Brain Res. 126, p. 175-86.

Kasteel van Linge A. and Maas A.d.l. (1990) Quantification of visuo-vestibular interaction up to $5.0 \mathrm{~Hz}$ in nomal subjects. Acta Otolaryng. (Stockholm) 110, p.18-24.

Lagally M. (1924) Vorlesungen über Vektor-Rechnung. Akademische Verlagsgesellschaft, Jelpzig.

Leigh R.I. and Zee D.S. (1983) The neurology of eye movements. F.A. Davis Company, Philadelphia.

Minken A.W. and Gisbergen van JA. (1996) Dynamical version-vergence interactions for a binocular implementation of Donders' Jaw. Vision Res. 36, p.853-867.

Nakayama, K. (1975), Coordination of extraocular muscles. In G. Lennerstrand, P. Bach-yRita (Eds.) Basic mechanisms in ocular motility and their clinical implications. New York Pergamon Press, p. 193-207.

Ot, D., S. H. Seidman and Leigh, R. J, (1992). The stability of luman eye orientation during visual fixation. Neurosci-Lett. $142, p, 183-186$.

Purkinje J.E. (1825) Beobachtungen und Versuche zun Phisiologie der Sinne. Reimer, Berlin.

Quaia C. and Optican L.M. (1998) Commutative saccadic generator is sufficient to control a 3-D ocular plant with pulleys. J. of Neurophysiol. 79, p.3197-3215.

Robinson D.A. (1969). The oculomotor control system: a review. Proceedings of the llEEE. $56, p \cdot 1032-1049$

Ruete C.G.T. (1853). Lehrbuch der Ophthalmologie. Bramschweig, 1846; 2nd edition, Vol.1, p. $36-37$

Schmabolk C. and Raphan T. (1994) Modeling three-dimensional velocity to position trans formation in oculomotor control. J. of Neurophysiol. 71, p.623-638.

Sharpe J.A. and Barber H. O. (1993). The vestibulo-ocular reflex and vertigo., Raven Press New York. 
Shlaer R. (1971) Shift in binocular disparity causes compensatory change in the cortical structure of kittens. Science 173, p.638-641.

Stater A.M. and Findlay J.M. (1975) The measurement of fixation position in the newbon baby. J. Exp. Child Psych. 20, p.48-273.

Nomal subjects. Acta-Otolaryngol. 117, p.796-809.

Thorn F., Gwiazda J., Cruz A., Bater J. and Held R.(1994) Eye alignment, sensory binocularity, and convergence in young infants. Invest Ophthalmol. Vis. Sci. 25, p.544-553.

Tweed D., Cadera $W$. and Vilis T. (1990) Computing three-dimensional eye position quatemions and eye velocity from search coil signals. Vision Res. 30, p.97-110.

Tweed D., Fetter M. Andreaki S., Koenig E. and Dichans J. (1992). Three-dimensional properties of human pursuit eye movements. Vision Res. 32, p. 1225-1238.

Tweed D. Visual-motor optimization in binocular control. Vision Res. 37, p. 1939-1951. Van Opstal J. (1998) Three-dimensional kinematics underlyng gaze control. In Model of neural networks IV. Eds. E.Domany, J.L. Van Hemmens and K. Sehullen. Springer Verlag.

Van Rijn L.J., van der Steen J. and Collewijn H. (1994) Instability of torsion during fixation: cyclovergence is more stable than cycloversion. Vision Res 34, p. 1077-1087.

Westheimer G. and Mitchell D.E. (1956) Eye movement responses to convergence stimuli. Arch. Ophthalmol. 55, p.848-856.

Westheimer G. and McKee S.P. (1975) Visual acuity in the presence of retinal-image motion. IOpt.Soc.Am. 65, p.847-850. 
Chapter 1 


\section{Chapter 2}

The Influence of Visual Input on the Gain of the Vestibulo- Ocular Reflex.

Jeroen Bosman, Marcel P.M. ten Tusscher and Herman Kingma.

Documenta Ophthalmologica 1999, vol. 99, p.83-92. 
In order to stabilise a fixation target on the retina, eye movements have to compensate for head movements. During slow head movements wisual feedback can control these eye mowements. During fast movements of the head, mainly the vestibulo-ocular reflex (VOR) controls eye movements, as visual feedback is too slow. However, visual feedback is an important factor in controlling the VOR; e.g. the gain of the VOR depends on the distance of the target. This study investigates the infuence of retinal inage position during fast head movements. The experiments were carried out in five human subjects using scleral search coils. The adaptation of each eye individually to a change of retinal position of a target was. examined during head shaking. The change in visual input was carried out by placing Fresnel prisms of different strengths in front of both eyes, thus inducing a change in retinal image position without changing the retinal slip. The results show, that both eyes make the appropriate corrections when the visual input changes, ever during fast head-movements. These corrections did not influence the gain of the VOR. From these results we conclude, that retinal image position besides retinal slip has a major influence on the monocular eye movements even at high head rotation frequencies. 


\section{1}

Introduction.

Human eyes tend to compensate for various head movements in otder to maintain a stable image of the point of fixation on the retina. One of these mowemenis is active head totation. Gaze stabilisation during active head rotation is accomplished by the co-operation of visual, auditory, vestibular, proproceptive (Mery $197 \mathrm{I}$ and Hine and Thon, 1987) and efference copy (Hine 1991) mechanisms. In particular the visual and vestibular inputs are responsible for the co-ordination of compensatory eye movements, called the vestibulo-ocular reflex (VOR).

The efficiency of both inputs varies with head velocities (and frequencies). The vestibular system is effective at head ratation frequencies between 1-10 $\mathrm{Hz}$ (Carpenter, 1988). The visual system on the other hand can follow a target moving at low frequencies $(0-2 \mathrm{~Hz}) \mathrm{At}$ high frequencies ( $>2 \mathrm{~Hz}$ ) ocular smooth pursuit becomes less effective (Kasteel-van Linge and Maas 1990, Atkin and Bender 1968). At these frequencies the target is not perceved clearly. This can be demonstrated by moving a finger in front of the eyes. The faster the movement, the more blurred the image becomes. Visual perception appears to be too slow at hightarget velocities. If one would hold the finger motionless and shake the head, we can still see the finger clear up to shake frequencies of $5 \mathrm{~Hz}$.

Nevertheless visual input remains an important aspect in this experiment. Placing of the target closer to the head results in two things. First, a change of image position occurs. To compensate for this a vergence eye movement is necessary to maintain binocular vision. Second, the movement of the image on the retina (the retinal slip) increases in size. To compensate for this slip, the eyes need to move faster than in the situation when the target is positioned in infinity. Therefore, a change of target position in depth during head shaking demands for a change in VOR gain (ratio between velocity of eye and head movement). However, are we able to change the gain during high-frequency head rotation? Do we perceive the position of the image? Do changes in vergence and subsequent changes in gain occur as a result of a change in image position only?

The role of retinal slip on the gain of the VOR has been pointed out earlier by Collewijn, Martins et al. (1983). Their conclusion is, that retinal slip is the main driving force for the control of the gain of the VOR. The aim of this study is to determine whether, besides retinal slip, retinal position also influences VOR gain during high-frequency luead movements.

This study investigates compensatory eye movements during active head shaking. A change in position of the target by means of a Fresnel prism should cause a change in vergence angle and a slight change in VOR gain. If the position is determined accurately by applying a diferent strength in prism for each eye, the adaptation has to be different lor each eye individually. 


\subsection{Method.}

\section{Apporatus}

Horizontal and vertical eye movements and head movements were simultaneously recorded using the seleral search coill technique (Robinson 1963) at $200 \mathrm{~Hz}$. Head movements were recorded using a $2 \mathrm{D}$-coil attached to the forehead, connected to a free torsion channel of the coll box. Vergence angle was defined as horizontal left eye minus right eye position. The subject sat on a stool with the head free. Subjects were instructed to keep their heads in the centre of the coil box. This is necessary because the coil box only has a uniform magnetic field in the centre. If the head moves outside a $30 \times 30 \times 30 \mathrm{~cm}$ area, the linearity of the system disappears. Linearity of the coll box was verified using a calibration device.
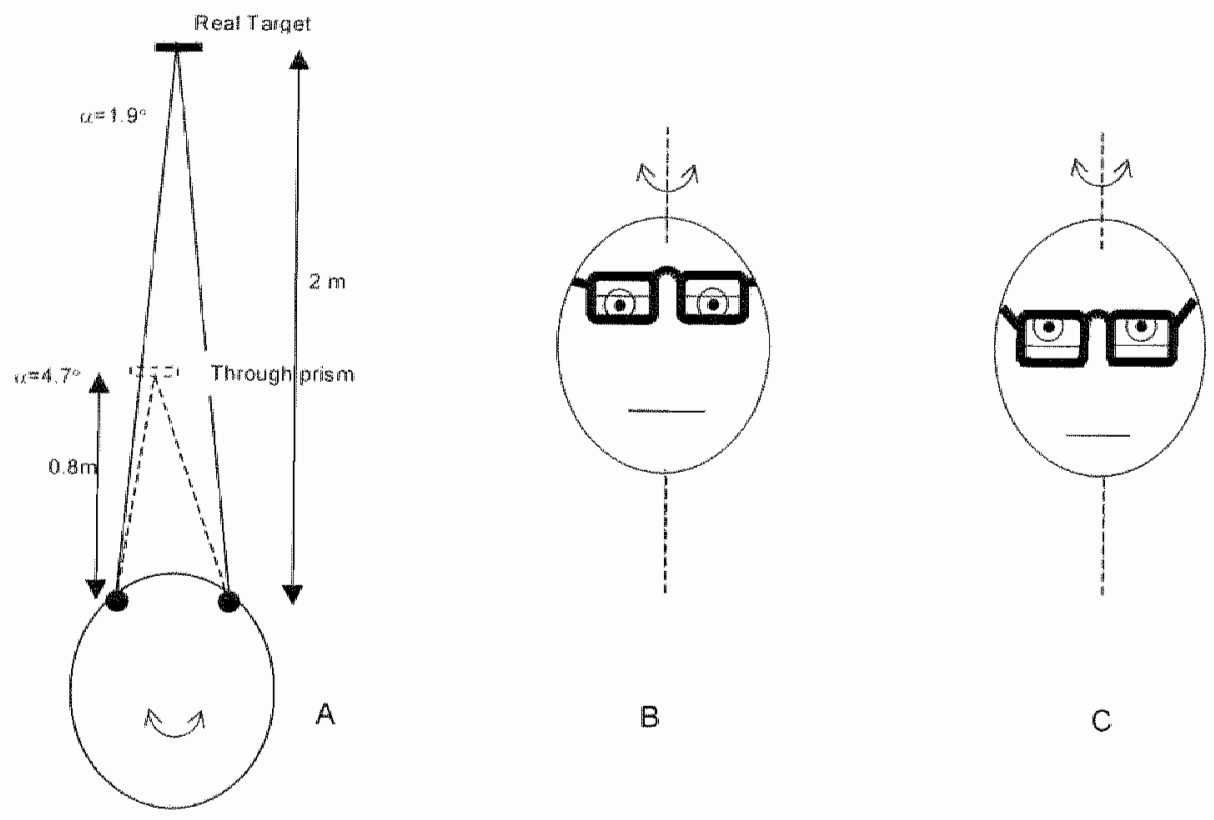

Figwe 2.1. Setup of the cuperiment. A) Top wiew: displacemen prism relocates the target without ewlarging or defochsing, awergence angle B) Frontat vicw: sabject wearing glasses with displacenent prisms at the bottom looking through the prism. C) Frontal wew: affer head rit the subject is looking twrough the normal glass.

\section{Procedinte.}

The subject fixated a word on a chart placed at 2 meters in fromt of the subject. The word at this distance subtended an angle of approximately $I$ degree. The set-up of the experiment is schematically drawn in ligure 2.1. The subject yaw-rotated his head actively for 16 seconds while listening to a rhythmic clicking sound. Each measurement was done twice. Three different head rotation frequencies were used: $0.5,2 \mathrm{~Hz}$ and maximum frequency. The subject wore glasses on which two fresnel prisms were motnted on the lower half of the glasses. The glasses were tirmly placed on the nose, to avoid any movement. The prisms were two basetemporal displacement prisms (right eye $4 \mathrm{D}$ and left eye $1 \mathrm{D}$ ). During the first experiment 
(prism-glass) the subject initially looked through the prisms at the target, while shaking the head. After 8 seconds the head was tilted slightly; thereby looking through normal glass at the target. This resulted in a vertical gaze angle displacement of approximately 10 degrees. The amplitude of head shaking was within 10 degrees, varying for each person and each trial. During fast head movements, the amplitude decreased to $0.5-1$ degree. The two prisms induce an optical displacement of the target, thereby demanding an immediate change of individual eye positions to regain binocular vision (see figure $2.1 \mathrm{~A}$ ). The experiment was repeated (glass-prism); but now the subjects initially looked through the glass. Then, after 8 seconds, they looked through the prisms. The whole procedure was repeated once lor each subject. The results (horizontal and vertical eye and head positions) were stored on dise using the Nystagliner Eyemovement System (Toennies, Würzburg).

\section{Subjects}

The subjects were $27(\mathrm{~A}), 39(\mathrm{~B}), 24(\mathrm{C})$ and $24(\mathrm{E})$ year-old males and one 27 year-old female (D), with no ocular dysfunction, $20 / 20$ vision and normal stereopsis. Subject D was myopic in both eyes, this was corrected by -3.5 glasses. All subjects had a dominant right eye. Prior to the experiment it was established that subjects had single vision when looking through the prisms. The maximum frequency of head-shaking of subjects $\mathrm{A}$ and $\mathrm{B}$ was $4 \mathrm{~Hz}_{\mathrm{z}}$, subjects $\mathrm{C}$, $D$ and $E$ 's maximum frequency reached up to $3 \mathrm{~Hz}$. All experiments were undertaken with the understanding and consent of the subjects.

\section{Data analysis:}

Before experiments, eye movements were recorded without the glasses to show any influences of head tilt on the eye mowements. The subjects tilted their heads slightly backward, as would resemble the glass-prism experiment.

The amount of eye position corrections made after head-tilt was scored manually. Because the prism strength was different for both eyes, each cye had to make a specific change of position. A prism of 1 diopter results in a change of target direction of approximately $0.57^{\circ} . \mathrm{A} 4 \mathrm{D}$ prism results in a $2.2^{\circ}$ change. Subjects wearing a $1 \mathrm{D}$ base-temporal $(\mathbb{B T})$ prism left and a $4 \mathrm{D}$ BT prism right, should have an increase in vergence angle of approximately $-2.8^{\circ}$ in the first and $2.8^{\circ}$ in the second experiment (see figure $2.1 \mathrm{~A}$ ).

Finally, VOR gain walues (velocity of eye versus head movements) were calculated. First, data were split up in two parts; before and after head tilt. In both parts gain values were determined. The horizontal eye and head movements were differentiated and peak values (i.e. saccades) removed using a 6-median filter. VOR gain values were calculated using a sinusoidal least-squares fit, using the Levenberg-Marquardt method. Gain values of each eye separately was deternined. A Wilcoxon, non-parametric statistical test was used to detcrmine differences in gain values between prisms and non-prism vision in each eye. 


\subsection{Results}

\section{Head ollt.}

Figure 2.2 shows an example of a head tilt of a subject without wearing the glasses. The plot shows horizontal and vertical eye and head movements. For all subjects, the backward head till resulted in a sudden decrease of vergence angle of approximately $0.5^{\circ}$. A forward tili resulted in an increase of vergence angle of approximately $0.5^{\circ}$. Calculation of vergence angle during the experiment with prisms should take this result into account.

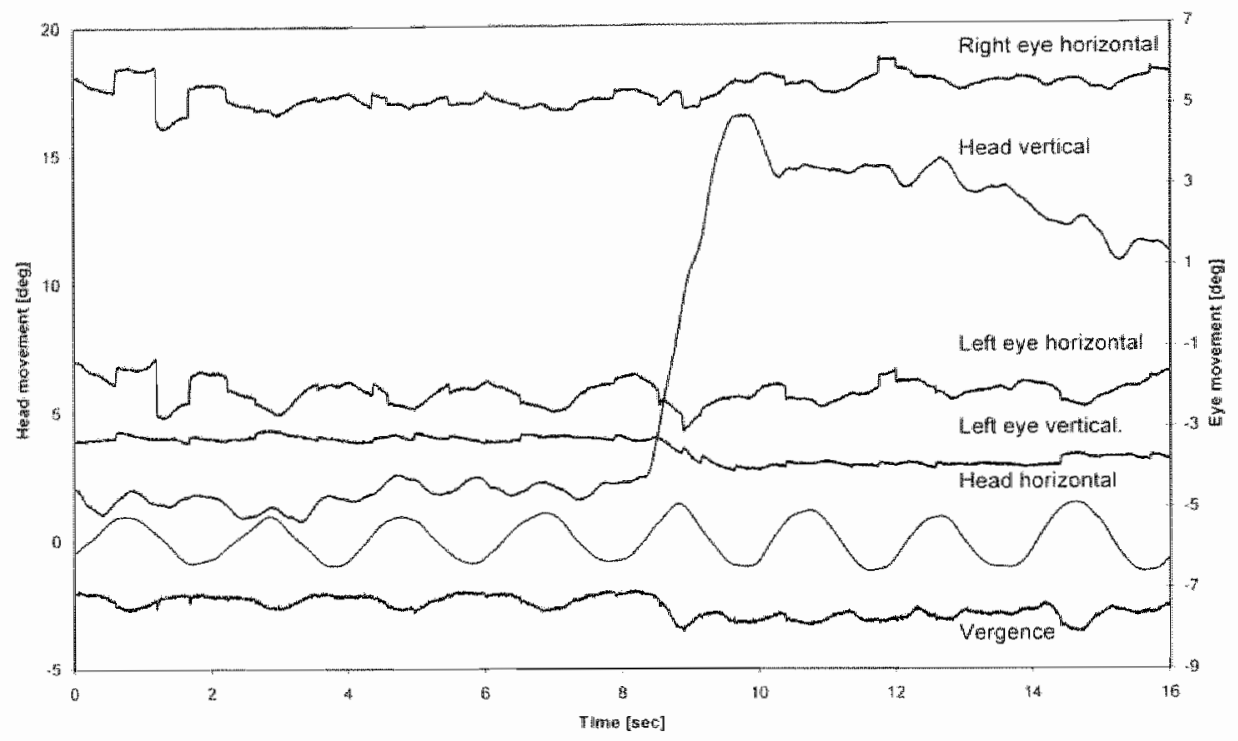

Figure 2.2. Eye and head positions of head tilt withow glasses against time in seconds during $0.5 \mathrm{~Hz}$ head rotation, with head horizontal divided by 10 and nergence angle = left-righ oye. N.B. posinions of eye movement waces are arranged up or down to provide a clear image.

\section{Head till with prisms}

Figure 2.3 presents some results of subject B. The left column illustrates the eye and head movements while looking through the prism during the first 8 seconds. After head tilt, the subject fixates the target through the glass without prism. The right column shows the reverse experiment. All subjects made individual eye movements in combination with combined saccades during all three head rotation frequencies. The right eye moved approximately $1.5^{\circ}$ nasal and the left eye moved approximately $0.5^{\circ}$ nasal in the glass-prism experiment. 

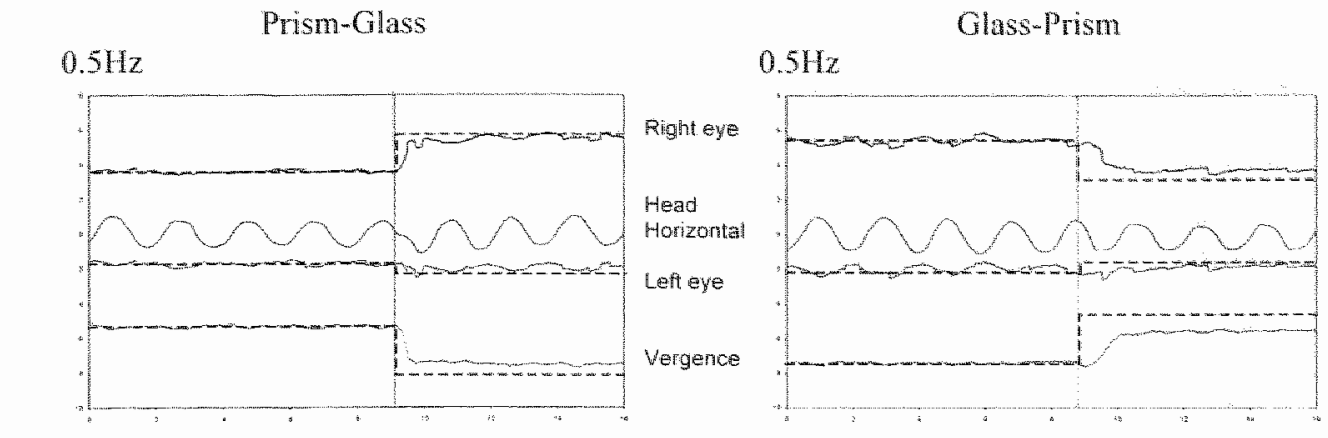

$2 \mathrm{~Hz}$

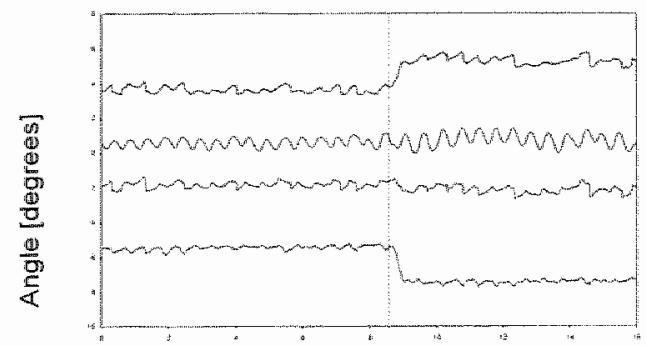

$2 \mathrm{~Hz}$

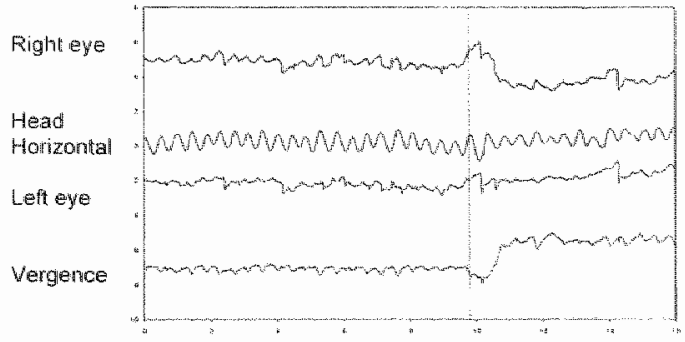

Maximum $\mathrm{Hz}$

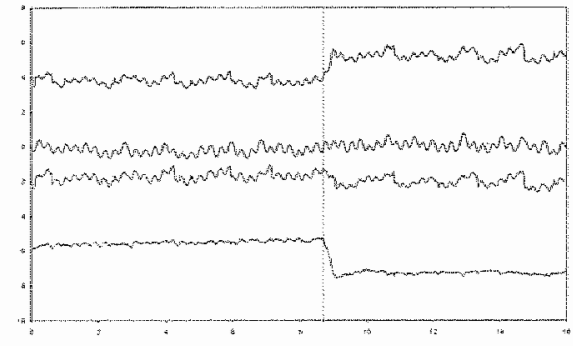

\section{Maximum $\mathrm{Hz}$}
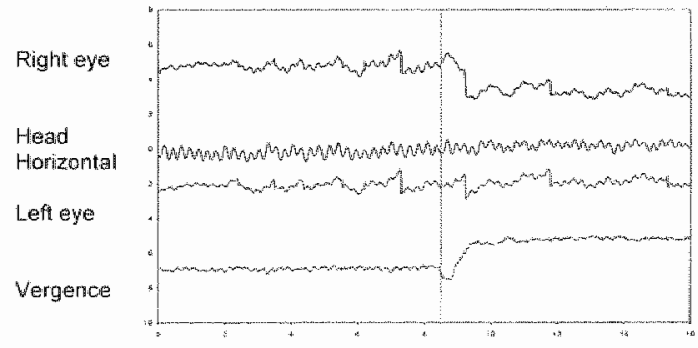

Time [sec]

Figure 2.3. Horizonal eye movements and horizonlal head (dvided by 10) movements of subject B. reprexentative for all subjects. Lefi: head th prism to glass. Right: glass to prism. Dotred wertical line: momen of head will. Dashed line: expected eye movements. The result shows, that eact gye makes the appropriate correction after head tilt: the right eye moved approximately $1.5^{\circ}$ masal and the lefi eye moved approximately $0.5^{\circ}$ nasal in the prism-glass experiment and vice versa. N.B. positions of eye movement traces are aranged up or down ro provide a clear image. 
Vergence angle.

Figure 2.4 shows the change in vergence angle for each subject averaged over wo trials compared with expected values. A positive change indicates an increase of vergence angle. Vergence angle is usually smaller than the expected angle, except subjects $d$ and $e$ during maximum head shaking in the prism-glass experiment.

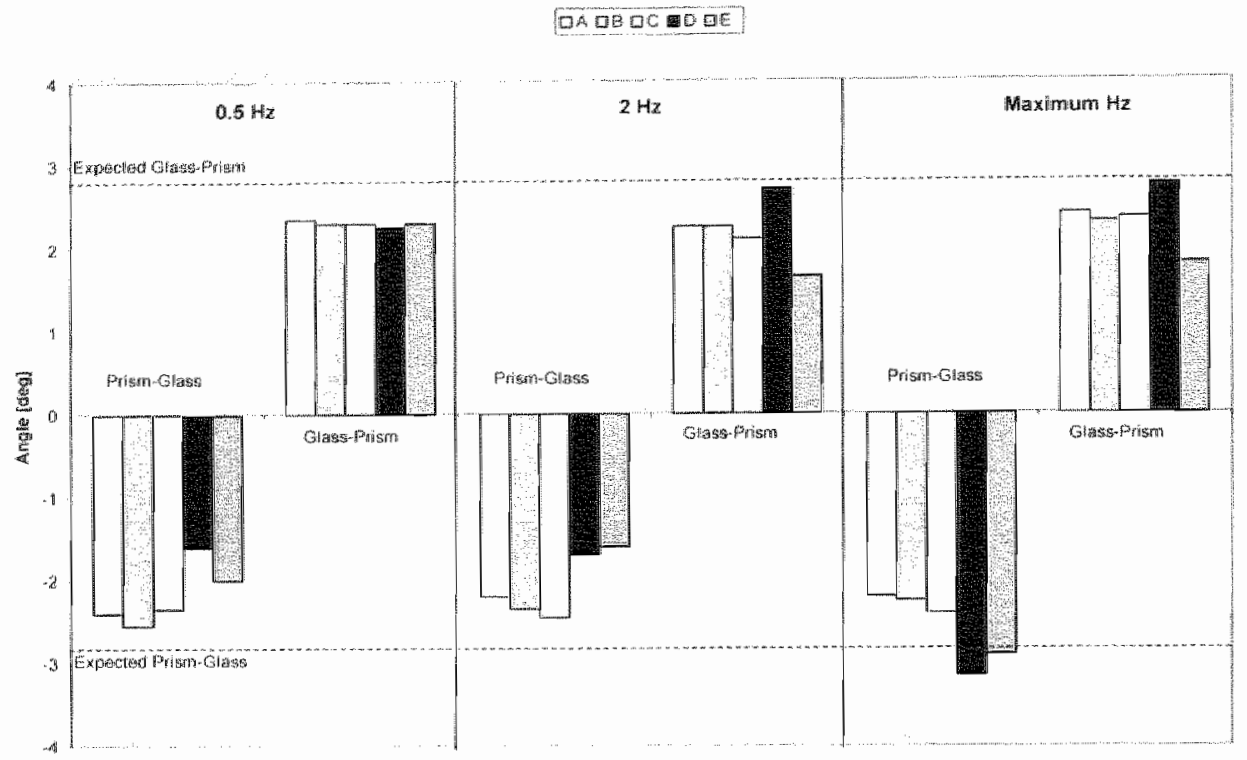

Figure 2.4. Change in vergence angle affer head wit of each swbject aneraged over wo trials. Above the data head-shake frequencies are shown. Dotied lines represent expected values of $2.8^{\prime \prime}$ and $-2.8^{\prime}$ for the glass-prism and prism-glass: experiment respectively.

\section{VORgain.}

The VOR gain (eye velocity/head velocity) was calculated for all frequencies before and after head tilt ror each eye individually. These results are plotted for each eye separately in figure 2.5. Average values with standard deviation of 4 experiments (twice glass-prism and twice prism-glass) are presented. Gain values in the experiment varied between 0.8 and 1.1 (a gain value of I means a perfect compensation of eye versus head movenents). A slight decrease in gain was observed, while the right eye was looking through the prism during maximum headshake trequency, compared to looking through the normal glass (Wilcoxon non-parametric $p=0.042$ ). In this situation, averaged gain value was 0.93 . 


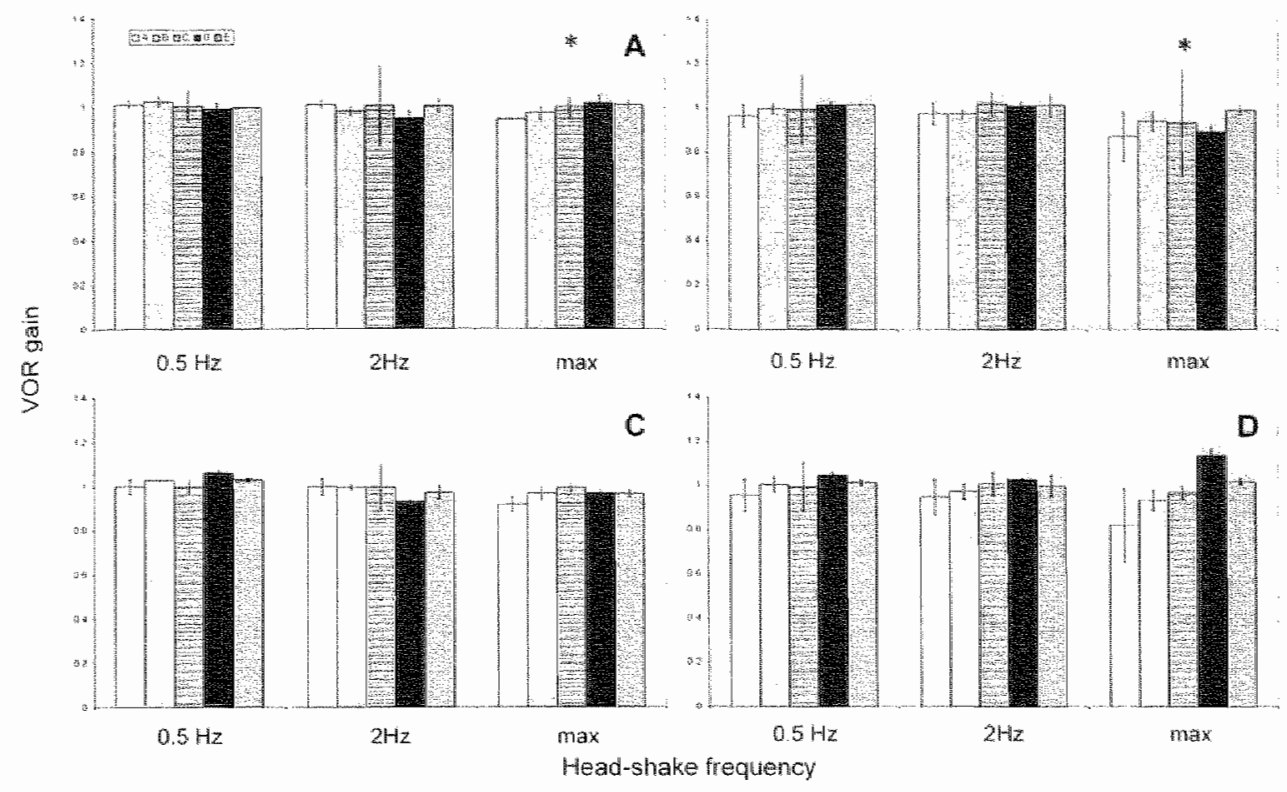

Figure 2.5. Averaged VOR gains of each subject with standard deviations of 4 values. The $x$-axis represents head-shake frequency: $0.5 \mathrm{~Hz}, 2 \mathrm{~Hz}$ and waximum. A) right eye glass B) right eye prism C) left eye glass D) left eye prism. All gain values are close to one. The situation marked with * represent significant different values between glass and prism vision: gain, mism $_{<}<$gain $_{\text {ghas: }}(p=0,042)$

\subsection{Discussion.}

Stabilisation of gaze is a complex interaetion of imputs from several sensory systems. In this study we investigated the interaction between visual inputs and the VOR. The role of visual inputs during high frequency rotation of the head is previously discussed in several studies (e.g. Hine and Thorn 1987 and Collewijn, Martins et al. 1983). "The effects of target distance (Paige 1989), long-term adaptation to prisms (Collewijn. Martins el al. 1983) and moving targets on the VOR (Das, Leigh ef al.1995) have been described. However, an active change of visual input during head rotation has not been investigated. In the present study we were interested in the dynamics of fast adaptation of the eyes to a new (visual) situation. By means of two displacement prisms we changed the position of the target on both retinas. Adaptation was imposed solely due to the change of visual input. This induces two reaclions. First, both eyes need to refoveate the image and second as a result of the first the gain has to change.

By using different prism strengths for each eye, an individual change in eye position is necessary to regain a projection of the image on the fovea of both eyes. The prisms used in the experiment were two base temporal displacement prisms (right eye $4 \mathrm{D}$ and left eye $1 \mathrm{D}$ ). We expected an increase in vergence angle of $2.8^{\circ}$. Our results show that adaptation of oye 
position takes place even at high head rotation frequencies ( 2 and $4 \mathrm{~Hz}$ ), although all subjects show a change in eye position smaller than expected. This is most likely compensated by sensory mechanisms. The infuence of change in retinal position caused by the prism, resulted in a change of vergence angle which was less ( $\angle 25 \%$ difference) than the expected $2.8^{\circ}$. All subjects show that adaptation takes place one eye at a time, although correction saccades take place in both eyes simultaneously. This result supports the hypothesis of Dell"Osso (1994) that there might be an inclividual ocular motor control of each eye, but also shows that a visual position change on the retina without a change in slip is perceived.

In this axperiment we investigated the influence of both prisms on the VOR gain. If a subject looks through both prisms, the vergence angle increases approximately $2.8^{\circ}$. This might be perceived as if the target is placed $80 \mathrm{~cm}$ in front of the subject instead of $200 \mathrm{~cm}$, although the size of the taget remains the same. With a target at a distance of 200 centimetres, the gain should be approximately 1.04. At a distance of 80 centimetres it should be approximately 1.12 (from Hine and Thom 1987). This would mean an increase of VOR gain of approximately 0.1. Our data do not show this increase of gain, a slight decraase can even be observed when the right eye looks through the prism, while the subjects shook their heads as fast as possible. Vuire, Tweed ef at. (1986) state that the occurring VOR gain adjustments during fast head movements are too fast to be mediated by the pursuit or visually driven vergence systems. Their explanation for these adjustments is that the ocular motor system makes use of a fast non-visual estimate of the current target location relative to the head, called the rarget locator network (TLN). This network processes visual, auditory, proprioceptive and vestibular inputs and calculates the craniotopic target position. The visual input updates the network, which moclulates the action of the VOR (Vilis 1993). How this update is accomplished has not been mentioned. We believe that, besides retinal slip, retinal image position also participates in updating the VOR gain. In our experiment these updates presumably take place at the moment when head velocities are slow, i.e. when head movemenis change direction. 


\subsection{References.}

Atkin. A. and Bender M. (1968) Ocular stabilisation during oseillatory head movements. Archives Neurology 19, p. $559-566$.

Carpenter R.H.S. (1988) Movements of the eye. London: Psion Limited.

Collewijn H., Martins A.J. and Steinman R.M. (1983) Compensatory eye movements during active and passive head movements: fast adaption to changes in visual magnification. Journal of Physiology 340, p. $259-286$.

Das V.E., Leigh R.I., Thomas C.W., Averbuch Teller L.A., Zivotolsky.A Z., Discenna A.O. and Dell'Osso L.F. (1995) Modulation of HF VOR during visual tracking in humans. I. Neurophysiol. 74, p.624-632.

Dell'Osso L.F. (1994) Evidence suggesting individual ocular motor control of each eye (muscle). J. Vestibular Res. 4, p.335-345

Hine T. and Thom F. (1987) Compensatory eye movements during active head rotation for near targets: effects of imagination, rapid head oscillation and vergence. Vision Res., 27. p.11639-1657.

Hine $T$. (1991) Effects of asymmetric vergence on compensatory eye movements during active head rotation. J. Vestibular Res. 1, p.357-371.

Kasteel van Linge A. and Maas A.J.J. (1990) Quantification of visuo-vestibular interaction up to $5.0 \mathrm{~Hz}$ in normal subjects. Acta Otolaryng. (Stockholm) 110, p. 18-24.

Meiry J.L (1971) Vestibular and proprioceptive stabilization of eye movements. In Bach-YRita,P. and Collins, C.C. (Eds) The control of eye movements, (p.483-496). New York:Academic Press.

Paige GD. (1989) The influence of target distance on eye movement responses during ventical linear motion. Exp. Brain Res. 77, p.585-593.

Robinson D.A. (1963) A method of measuring eye movement using a scleral search coil in a magnetic field I.E.E.E. Trans. Bio-Med. Eng. 10, p.137-145.

Wire E., Tweed D., Milner K. and Vilis T. (1986) A re-xamination of the gain of the VOR. J. Neurophysiol., 56, p. $439-450$

Vilis $T$. (1993) Interactions between the angular and translational components of the VOR. The vestibulo ocular reflex and vertigo. New York: Raven Press 
Chapter 2 


\section{Chapter}

3

Three Dimensional Eye Movements during Horizontal Smooth Pursuit in Patients with Micro-strabismus and/or Amblyopia.

J. Bosman, M.P.M. ten Tusscher, I. de Jong and H. Kingma 
Cyclovergence stability is a prerequisite for normal retinal correspondence. Here we test whether the stability of three-dimensional binocular eye movements during smooth pursuit is comparable in normal subjects (5) and subjects with diminished stereopsis. Vergence stability and temporal correlation between horizontal and torsion signals were determined while subjects were viewing monocularly and binocularly. In all subject groups, a temporal dissociation between horizontal and torsional eye movements was observed. In all patients with strabismus and/or amblyopia, horizontall vergence stability depended on fixation condition. Subjects with micro-strabismus (4) showed increased cyclovergence instability. Subjects with micro-strabismus and additionally amblyopia (2) showed increased horizontal vergence instability. 


\subsection{Introduction.}

In order to allow full usage of stereopsis, images on the retina of both eyes need to correspond to and be stable within certain margins. Various studies (Enright 1990 and Ferman, Collewijn ef al. 1987) have shown that the margins for horizontal, vertical and torsional stability differ. Especially ocular torsion appeared to be relatively imprecise, which was explained by the hardly visible effect of torsional instability in the area around the fovea. The effect is profoundly visible in the periphery of the visual field, where acuity is reduced. It has been shown also, that during steady fixations (Enright 1990 and van Rijn, van der Steen er al.1994) and during smooth asymmetric vergence (Iwins, Porrill er al. 1999), the variability of torsional differences between the eyes (cyclovergence) is much smaller than monocular torsional variability.

During eye movements, the accuracy of eye positioning decreases. Westheimer and Mckee (1973) measured the stability of eye movements during smooth pursuit. When the eye passed transiently through the straight-ahead position, deviations of up to several degrees of torsion were detected. These deviations were unsystematic and varied idiosyneratically between subjects, right and left eyes, trajectories and directions of pursuit. Ott and Eckmiller (1989) performed a similar experiment using tv- and scanning laser ophthalmoscopy; fixation and pursuit of a horizontal moving target were measured in humans and monkeys. In both humans and monkeys, torsion modulated sinusoidally during foveal pursuit, approximately in phase with horizontal eye position. Torsion showed a considerable intra- and inter-individual fluctuation with regard to phase and modulation depth relative to the pursuit movements, and was interspersed with irregularly occurring rapid deflections. Various other studies (e.g. Straumann, Zee ef al. 1996) confirmed the deviations in torsion not only during pursuit, but also during saccades and blinks.

If the eyes are not aligned nomally, i.e. strabismus, stereopsis is most often subnomal or absent. Therefore, the stability of eye movements needed for correspondence and stereopsis may be less. Previous investigations in subjects with diminished stereopsis due to strabismus have shown, that during fixation, horizontal vergence instabillty is higher than in normal subjects (Van den Berg, van Rijn et al. 1995 and van Rijin, ten Tusscher ef al. 1998). However, the accuracy of positioning during eye movements has not been studied. In the present study, we investigated pursuit eye movements in four subjects with micro-strabismus (misalignment smaller than 5 degrees) of which two had amblyopia and in one subject with amblyopia due to anisometropia. The results were compared with 5 nomal subjects. 


\subsection{Methods.}

Subjects.

Eye movements were recorded in ten subjects after giving informed consent. Five normal subjects and five paticnts participated (Table 3.1).

Table 3.1. Description of subjects participating in the experiment.

\begin{tabular}{|c|c|c|c|c|c|c|c|}
\hline Groups & Name & Gender. & Age & $\begin{array}{l}\text { Esoliopic } \\
\text { Eye }\end{array}$ & $\begin{array}{l}\text { Vistal acuiti } \\
\text { Right eye }\end{array}$ & Left eye & Stereopsis \\
\hline \multirow{5}{*}{ Contrals } & $M$ & Female & 27 & . & $20 / 20$ & $20 / 20$ & $60^{\circ}$ random dot \\
\hline & $P$ & Femate & 23 & - & 20120 & $20 / 20$ & $60^{\prime \prime}$ random dot \\
\hline & V & Female & 27 & - & 20120 & $20 / 20$ & $60^{\text {.2 }}$ random dot \\
\hline & $j$ & Male & 29 & - & 20120 & $20 / 20$ & $60^{45}$ random dof \\
\hline & $W$ & Wale & 31 & - & $20 / 20$ & $20 / 20$ & $60^{33}$ randiom dot \\
\hline \multirow{2}{*}{ Micro-strabismus } & L & Femalle & 23 & Right & $20 / 20$ & $20 / 20$ & $460^{\circ}$ random dot \\
\hline & $\mathrm{D}$ & Male & 28 & Left & $20 / 20$ & $20 / 20$ & $460^{\prime \prime}$ random dol \\
\hline \multirow{2}{*}{$\begin{array}{l}\text { Miero-strabismus } \\
\text { with amblyopia }\end{array}$} & $\mathrm{RI}$ & Male & 63 & Left & $20 / 20$ & $20 / 100$ & Positive Tilmus fly \\
\hline & $R$ & Male & 38 & Left & $20 / 25$ & 20180 & Positive Tilmus fiy \\
\hline $\begin{array}{l}\text { Amblyopia due to } \\
\text { anisometropia }\end{array}$ & 1 & Male & 31 & - & $20 / 100$ & 20115 & Positive Tilmus fly \\
\hline
\end{tabular}

\section{Protocoland wisual stimulus.}

Subjects were seated on a stool at the centre of the coil box with the head fixed in a chin rest and against a forehead rest. Subjects were placed in a dimly lit room, facing a white wall at 1.65 meters. The realistic visual stimulus was a pendulum: a piece of metal $(5 \times 2 \mathrm{~cm}$ tapered cylinder) hanging at the end of a 1.2 meter long, thin rope. The amplitude of the horizontal pendulum-movement was approximately 10 degrees visual angle. Vertically, the amplitude was smalter than 0.7 degrees. Due to the small size of the piece of metal the thin rope was not visible when patients were wearing coils) no torsional stimulus was expected. Distance between stimulus and subject was 1.6 meter, the distance between the stimulus and the wall 5 centimeters. Frequency of the movement was $0.45 \mathrm{~Hz}$, resulting in a horizontal velocily. ranging from 0 to $28 \mathrm{degrees} / \mathrm{s}$. An experiment consisted of six measurements of 25 seconds ach. During this time period, no decay was observed in amplitude of the pendulum. During these intervals, subjects were viewing under three circumstances: binocularly, right eye only and left eye only. The subject obtained monocular vision by means of an occluder, hand-held by the subject. thus allowing fast changes of viewing conditions between experiments. Subjects were asked not to blink during recordings. In four subjects, measurements were repented after a few waeks. 
Recording techniques and data analysis.

Thre -dimensional eye movements were recorded using the scleril search coil technique (Robinson 1963). Combination coils and measurement devices were supplied by Skalar, Delft, The Netherlands. Prior to each experiment, gain and offset of the coils were calibrated using a calibration device (gimbals system) placed near the centre of the coll box. The coils were placed accurately on the eye and the subjects were asked not to blink during the experment. Digitisation was performed using a 12 bit ad-converter at $200 \mathrm{~Hz}$, range of eye movements were limited to \pm 40 degrees. The data from the measurenents were used in a matrix transformation (Ferman, Collewijn et al. 1987) for correction of coil misalignment and of non-linearity's between coil voltages and rotation angles. This way we obtained veridical eye positions relative to an earth-fixed co-ordinate system that were free of cross-coupling artefacts due to coil misalignment. Finally, data were stored on disc using a personal compater for further off-line analysis. All data were carefully checked lor coil slippage by checking for slow drift in the torsion signal of the coils over a period of approximately 20 seconds (van Rijn, van der Steen et al. 1994).

All eye rotations were expressed in Fick coordinates. This implies that torsion was expressed as rotation about the line of sight. Now torsion is directly related to retinal image rotation (van Rijn, van der Steen et al. 1994). Off-line analysis consisted of horizontal, vertical and torsional vergence (cyclovergence) stability and phase shift calculations. Vergence angles were calculated by subtracting right minus left eye movements. Vergence stability was expressed as standard deviation of vergence in one trial of 25 seconds. The values between subject groups were compared using a non-parametric Mann-Whitney test. All reported pvalues are calculated assuming two-sided alternative hypothesis and signilicance was assumed when $p \leq 0.05$.

Donders' law prohibits a directional influence on eye position (Donders 1847). However, in this experiment hysteresis was observed in amount of torsion in the straight-ahead position between coming from the right and left. The amount of hysteresis can be described with two factors: torsional amplitude and temporal phase shift between horizontal and torsional data The amount of torsion during horizontal smooth pursuit varies between subjects and between experiments, since torsional amplitude depends on the orientation of Listings " plane (Helmholtz 1910). If the reference position (straiglt-ahead positionis is orthogonal to listing"s plane, no torsion would be observed during pure horizontal and vertical eye movements (secondary positions). If the reference position is not orthogonal to Listing's plane, torsion will be measured during horizontal and vertical eye movements. Additionally, when using Fick's coordinate system, false torsion will be measured when the eyes move to tertiary positions. In our experiment, the amount of false torsion can reach I degree (Robinson 1975). The orientation of Listings" plane can only be determined empirically. In this experiment Listing"s plane was not measured, since only horizontal smooth pursuil cye movements were carried out. In order to calculate Listing's plane accurately, it is necessary that both horizontal and vertical eye movements be carried out. In this experiment, vertical cye movements were smaller than one degree, which was too small for an accurate calculation of Listing"s planes. As a result, no distinction can be made between secondary en tertiary conditions, true and false lorsion. This can therefore also influence the amount of hysteresis.

If an eye obeys Donders' law, no phase shifts between horizontal and torsional cye movements should be observed, since phase shifts would lead to hysteresis. Phase shifts are independent of the orientation of Listing's planes or coordinate system used. Therefore 
theoretically, phase shifts should be a good representation of coupling between horizontal and torsional cye movements: a zero phase shift would indicate no bysteresis and a strong coupling.

Calculation of phase shift was performed with the following procedure:

- Saccades in horizontal and torsional signals were removed, since saccades can lead to violations of Donders' law (e.g. Straumann, Zee et al.1996). This was accomplished as follows: velocities of two subsequent sample points from horizontal eye movements larger than 30 degrees/sec and torsion signals larger than 15 degrees/sec were removed. Fitting a linear trend with a least squares routine to the data and subtracting this trend from the data removed drift, resulting from the saccade removal.

- Data were divided into segments of 3 seconds each and a sinusoidally fit was applied to the horizontal eye movement. The frequency obtaned from this calculation was entered into the fit of the torsional eye movements; this way the horizontal and torsional functions had the same frequency component for each eye.

- All nine 3-second parts of each eye were averaged to obtain the overall amplitude and phase difference with standard deviation.

A possible remaining artifact, namely torsional blips (Tweed, Misstisch et al. 1994), was not removed with this procedure. Tweed, Misslisch et al. (1994) showed, that torsional blips smaller than 2 degrees occurred after a horizontal saccade of 60 degrees. The oculomotor models described in that paper predict, that blip size is linearly related to saccade amplitude. In our experiment, horizontal catcli-up saccades were smaller than 5 degrees. This would mean that the expected torsional blip amplitudes in our experiment do not exceed 0.2 degrees, which resembles the noise level of torsional eye movements.

A non-parametric Wilcoxon signed rank test was performed to see whether phase shift differences between left and right eye were significant. 


\section{Results.}

Control subjects showed largely conjugate eye nowements. Figure 3.1 shows data of one subject (V), representative for all normal subjects. Positive values for horizontal traces are to the left, for vertical traces down and for torsional traces clockwise. All eye movements were smooth and uniform during each trace. Vertical eye novements showed small double frequency fluctuations, compared to the horizontal and torsional movements, caused by a slight upward movement of the pendulum in lateral positions.

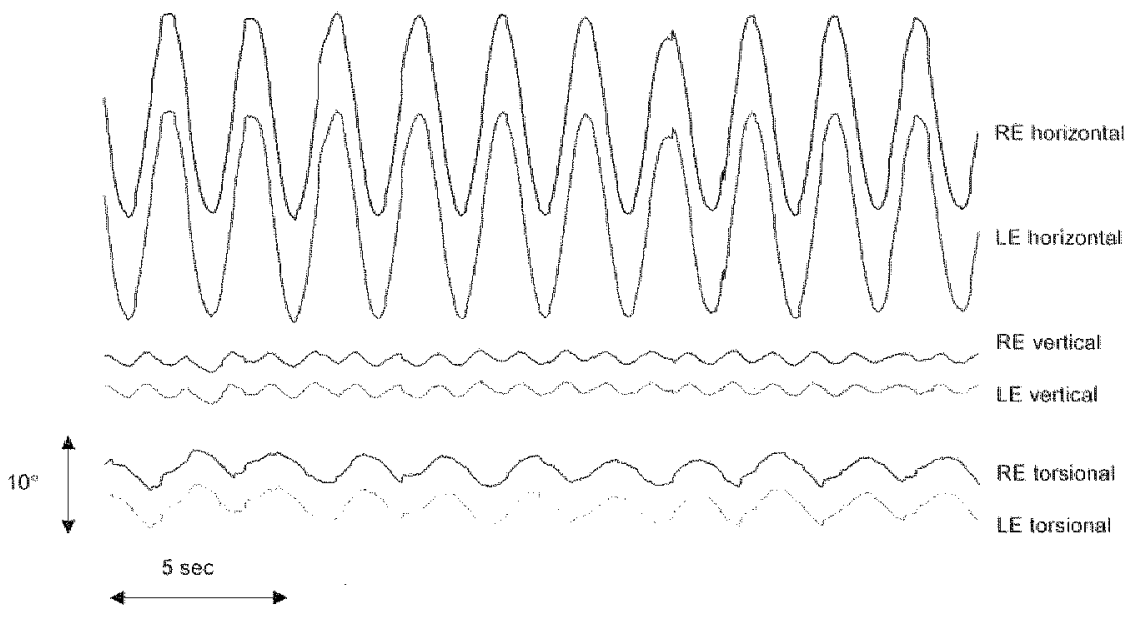

Figure 3.1. Typical recondings of control subjects (subject W). Part of one trial lasting 25 sec showing horizontal, vertical and rorsional right (RE) and lef (LE) eye movements in degrees. The tracings are shiffed werical to improve visualisation. Tracings show largely conjugate eye movemens. Verrical aye movements show dowble frequency caused by stight what movenent of the pendulum in extreme positions.

In micro-strabismus without amblyopia, ocular traces were overall smooth with occasionally a saccade. In amblyopia, more saccades were observed in all traces. 


\section{Vergence srablity}

In all groups, small variations in vergence angle were detected. Figure 3.2 shows typical recordings of a nomal subject (Figure 3.2a) and a subject with strabismus and amblyopia (Figure 2b). Negative vergence angles represent a convergence eye movement.

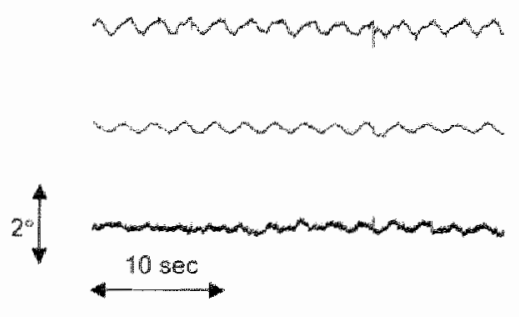

A
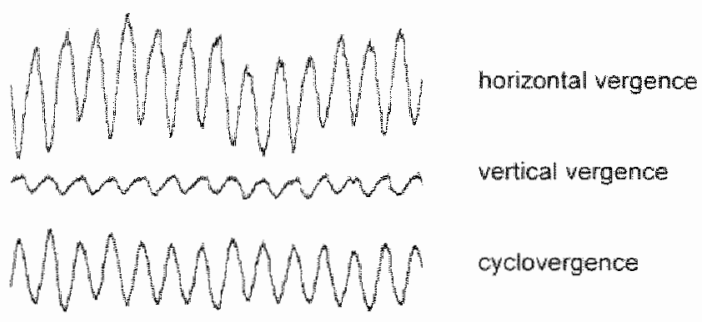

cyclovergence

B

Figure 3.2. Example of horizontal, wertical and torsional vergence (= righr eyelof cye sighal). The tracings are shifted vertical for better visuatisation. Swbjects are looking binocularly at a pendulumy for 25 seconds. A) control subject. (V) B) subject with amblyopia. (R).

Variability of horizontal, vertical and torsional vergence was determined for all subjects by means of calculating standard deviations of vergence in each trial (Table 3.2). 
Table 3.2. Variability of horizontal $(H)$, vertical $(B)$ and torsional $(T)$ vergence (= right eye- left eyel expressed in standard deviations in degrees of one ntal of 25 seconds. Two conditions: binocular and monocular vision. Monoculat vision is divided in right and left eye for the comrol subjects, and nownal and affected oye for parients.

\begin{tabular}{|c|c|c|c|c|c|c|c|c|c|c|}
\hline \multirow[t]{2}{*}{ Groups: } & \multirow[t]{2}{*}{ Subjects } & \multicolumn{3}{|c|}{ Binocular vision } & \multicolumn{3}{|c|}{$\begin{array}{l}\text { Monocular vision } \\
\text { (nomal or right } y \text { ) }\end{array}$} & \multicolumn{3}{|c|}{$\begin{array}{l}\text { Monacular vision } \\
\text { (affected or left eye) }\end{array}$} \\
\hline & & H & V & $\mathrm{T}$ & $\mathrm{H}$ & v & $T$ & $\mathrm{H}$ & y & $\mathrm{T}$ \\
\hline \multirow[t]{5}{*}{ Controls } & V & 0.16 & 0.07 & 0.12 & 0.2 & 0.13 & 0.18 & 0.18 & 0.18 & 0.21 \\
\hline & $M$ & 0.20 & 0.13 & 0.24 & 0.29 & 0.11 & 0.27 & 0.18 & 0.07 & 0.29 \\
\hline & $W$ & 0.13 & 0.09 & 0.08 & 0.22 & 0.12 & 0.11 & 0.17 & 0.09 & 0.07 \\
\hline & $P$ & 0.24 & 0.12 & 0.19 & 0.31 & 0.12 & 0.33 & 0.20 & 0.09 & 0.23 \\
\hline & $\sqrt{ }$ & 0.13 & 0.47 & 0.16 & 0.69 & 0.50 & 0.36 & 0.34 & 0.46 & 0.17 \\
\hline \multirow[t]{4}{*}{ Strabismus } & $\bar{D}$ & 0.36 & 0.09 & 0.44 & 0.66 & 0.08 & 0.48 & 0.37 & 0.05 & 0.41 \\
\hline & $\mathrm{L}$ & 0.22 & 0.11 & 0.45 & 0.50 & 0.13 & 0.45 & 023 & 0.13 & 0.34 \\
\hline & Ri & 0.52 & 0.32 & 0.30 & 0.72 & 0.33 & 0.94 & 1.53 & 0.58 & 0.48 \\
\hline & $\mathrm{R}$ & 0.91 & 0.16 & 0.56 & 1.14 & 0.19 & 0.76 & 1.06 & 0.19 & 0.23 \\
\hline $\begin{array}{l}\text { Amblyopia due } \\
\text { to anisom. }\end{array}$ & $T$ & 0.59 & 0.20 & 0.52 & 0.69 & 0.36 & 0.47 & 1.82 & 0.35 & 0.43 \\
\hline
\end{tabular}

In normal subjects no significant difference was observed in stability of horizontal, vertical and torsional vergence eye movements. Monocular and binocular wewing conditions had no influence on vergence stability.

In patients with micro-strabismus and/or amblyopia, four results were observed:

- Horizontal vergence stability decreased, when subjects looked monocularly

(Wilcoxon: $p=0.04$ ).

o In all subjects with amblyopia, horizontal vergence was less stable compared to the control group (Mann-Whitney: $\mathrm{p}<0.04$ ).

- In all viewing conditions, vertical vergence stability was higher than horizontal and torsional vergence stability (Wilcoxon: $\mathrm{p}=0.04$ ).

V Variability of cyclovergence was significantly higher compared to the control group (Mann-Whitney: $\mathrm{p}<0.05$ ).

Phaseshiff between horizontal and towsowal eye movements.

Deviations in ocular torsion were found when the eye passed transiently through the straightahead position (hysteresis). The direction of approach had a clear influence on the amount of ocular torsion. Hysteresis was observed in all subjects; deviations up to 3 degrees in ocular torsion were observed in the straight-ahead position when the target approached from the left and right. Figure 3.3 shows an example of such a hysteresis curve. 


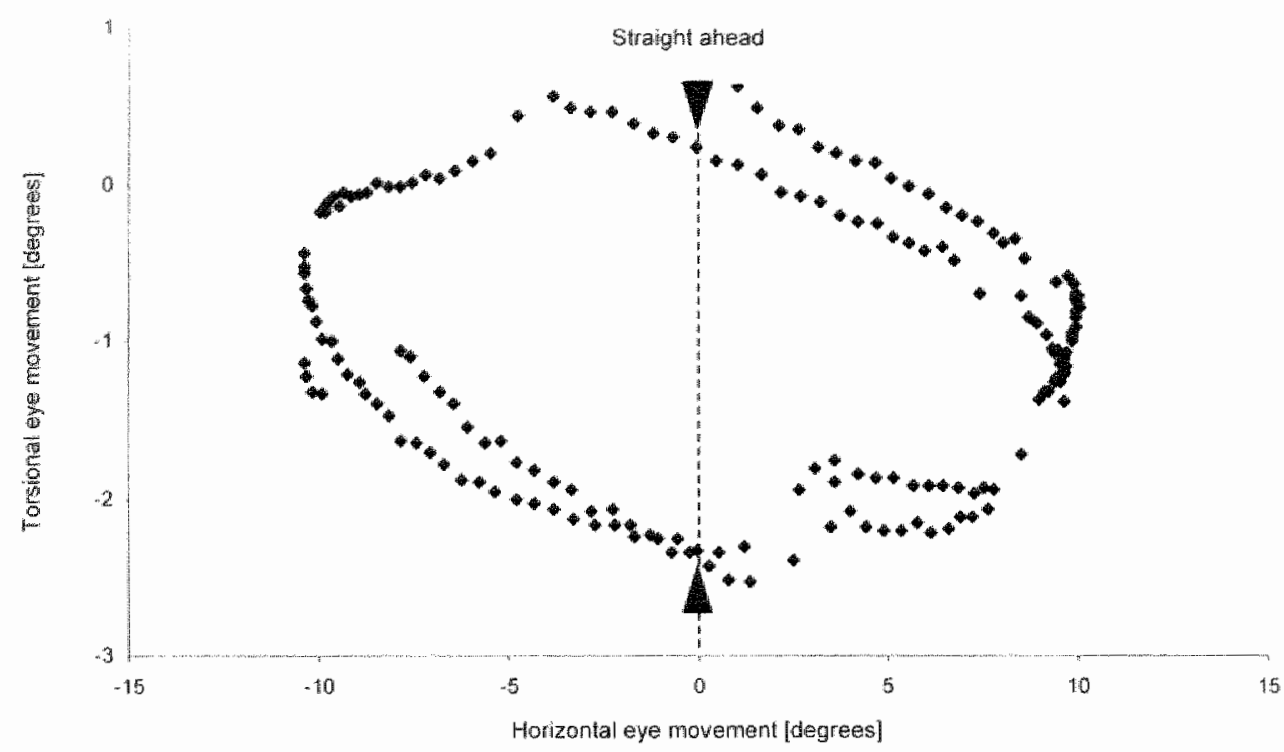

Figure 3.3. Topsional versus horizontal righ eye movement of control subjed $r$, in a period of 4 second ( 2 periods of pendulum movement). Trace shows hysteresis of approximately 2 degrees in the straight-ahead position (indicated by arrows).

Before calculating phase shifts, all saccades resulting from eye blinks and 'catch-ups' were removed from horizontal and torsional traces. The resulting torsional traces were sinusoidally, with frequencies identical to the frequency of the horizontal eye movement; the amplitude did not exceed 3 degrees. Three examples are depicted in Figure 3.4 . 


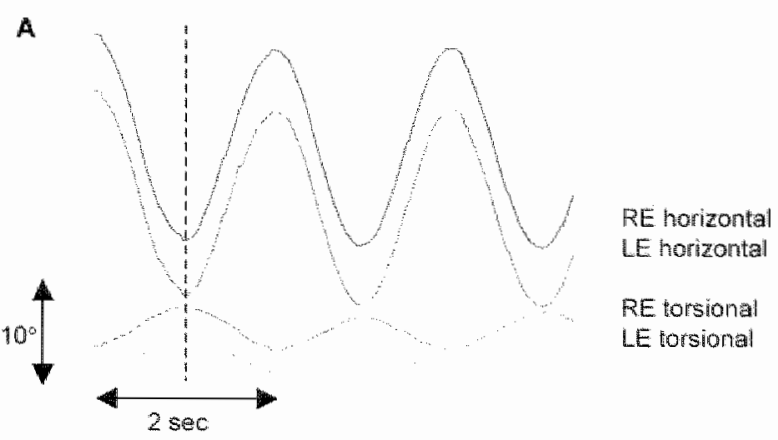

$B$
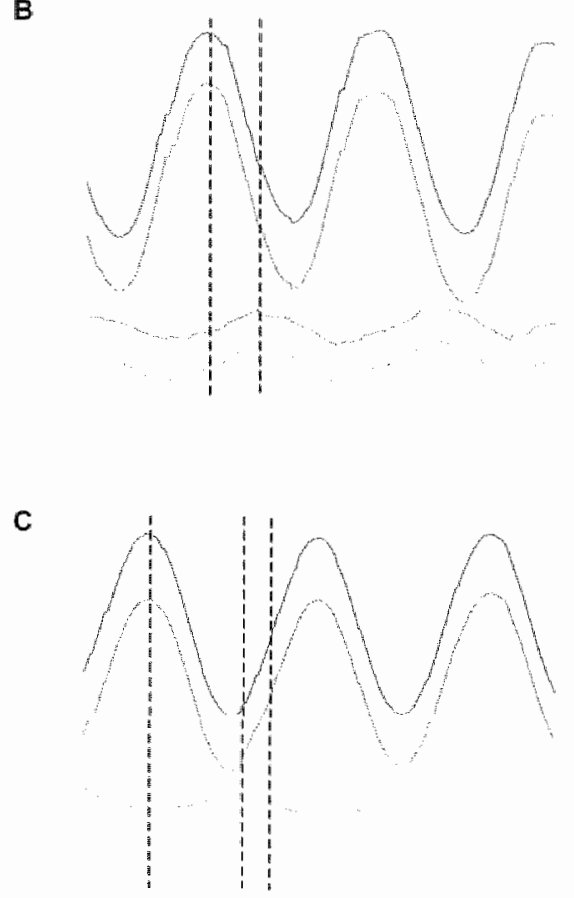

Figure 3.4. Tracings of horizontal and forsional eye mowements of three subjects, dotted lines clarify phase differences. A) Torsion signals are is phase with horizontal signals (control subject, d) B) Phase lag between horizontal and torsional eye movement is present (conirol subject, W) C) Difference in phase shiff berween both eyes (swbject with micra-strabismus. D). The tracings are shiffed vertical to improve visualisation. All subjects performed the tests for the first fime and the experimental conditions were similar for all swbjects.

Figure 3.4 a shows no phase difference between horizontal and torsional eye movement. Figure $3.3 \mathrm{~b}$ indicates a phase shift similar in both eyes. Figure $3.3 \mathrm{c}$ shows the response of a subject, where the amount of phase shift differs in both eyes: the right eye shows no phase 
shif, while the left eye shows a phase shift of approximately 50 degrees. Results of the sinusoidally fit procedure are presented in Table 3.3.

Table 3.3. Average ( 1 standard deviaion of phase difference between horizonat and rorsionat eye movements in degrees; $B I=$ both eyes, $R E=$ right aye and $L E=$ left eye fixating. Last column presents significance of phase difference between left and right eye tested with Wilcoxon signed rank test (positive $(+)$ if $p<0.05$; negative (-) if $p>0.05$ wo sided). No phase shiff could be calculated due to non-linear, non-sinusordally rorsianal response in the amblyopic eye.

\begin{tabular}{|c|c|c|c|c|c|}
\hline Glimos & Sulbjed & Fryation & $\begin{array}{l}\text { Phase } \\
\text { RE }\end{array}$ & $\begin{array}{c}\text { Phase } \\
\text { LE }\end{array}$ & $\begin{array}{l}\text { Phase diff: } \\
\text { od-os } \\
\text { [0<0 05] }\end{array}$ \\
\hline \multirow[t]{15}{*}{ Controls } & W & Bil & $441+9.4$ & $443 \pm 7.7$ & - \\
\hline & & REE & $51.4 \pm 5.0$ & $578 \pm 7.5$ & + \\
\hline & & LE & $58.7 \div 19.5$ & $54.5 \pm 13.0$ & - \\
\hline & $M$ & 81 & $28.9+6.9$ & $25.8 \pm 7.7$ & - \\
\hline & & $R E$ & $15.3 \div 7.0$ & $149 \pm 76$ & - \\
\hline & & LE & $12.4 \pm 10.2$ & $119 \pm 8.8$ & $=$ \\
\hline & W & $\mathrm{BI}$ & $-12.5+9.5$ & $-17.9+3.5$ & . \\
\hline & & RE & $-11.4 \pm 46$ & $-16.1 \pm 6.0$ & - \\
\hline & & LE & $-7.3+3.6$ & $-10.9 \pm 5.4$ & - \\
\hline & $\mathrm{P}$ & 81 & $8.9 \pm 6.6$ & 2.5148 & + \\
\hline & & $\overline{R E}$ & $7.1 \pm 63$ & $-1.4 \pm 4.4$ & + \\
\hline & & LEE & $38 \pm 7.0$ & $-09 \pm 48$ & + \\
\hline & $J$ & $\mathrm{BH}$ & $-7.7 \pm 4.7$ & $-12.4+50$ & + \\
\hline & & $R E$ & $3.0 * 4.5$ & $-1.8+5.7$ & + \\
\hline & & LE & $-43 \pm 2.4$ & $-6.6 \pm 2.2$ & - \\
\hline \multirow{12}{*}{$\begin{array}{l}\text { Microm } \\
\text { strabismus }\end{array}$} & $\bar{D}$ & $\mathrm{Bil}$ & $-236+6.3$ & $.75 .8 \pm 7.6$ & 4 \\
\hline & & $\mathrm{RE}$ & -20.4 H. 7.3 & $-622 \pm 9.1$ & + \\
\hline & & LE & $-21.5+11.7$ & $-56.6+24.5$ & + \\
\hline & $\mathrm{L}$ & B & $90=49$ & $9.1 \pm 2.3$ & - \\
\hline & & $\mathrm{RE}$ & $10.1 \pm 1.8$ & $7.9 \pm 2.3$ & + \\
\hline & & LE & $8.2 \pm 3.7$ & $6.8+36$ & - \\
\hline & $\mathrm{Ri}$ & $\mathrm{BI}$ & $-15.9+13.6$ & $-3.8+56$ & + \\
\hline & & $\mathrm{RE}$ & $-19.2 \pm 119$ & $3.7 \pm 15.4$ & + \\
\hline & & LE & $-30.6 \pm 17.5$ & $-14.5+7.8$ & 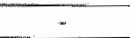 \\
\hline & $\mathrm{R}$ & $\mathrm{BI}$ & $-3.8+20.5$ & $*$ & $x$ \\
\hline & & RE & $-212+18,0$ & $29.8+26.0$ & + \\
\hline & & LE & $*$ & 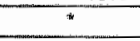 & $*$ \\
\hline \multirow{3}{*}{$\begin{array}{l}\text { Amblyopia dus } \\
\text { to } \\
\text { anisometropia }\end{array}$} & 1 & $\mathrm{~B}$ & $46,7+141$ & $39.2 \pm 6.6$ & - \\
\hline & & $\mathrm{RE}$ & $530+198$ & $40.9 \pm 103$ & m \\
\hline & & LE & $78.9 \pm 18.2$ & $50.6 \cdot 10.2$ & 4 \\
\hline
\end{tabular}


Phase shift walues had large inter-individual variability in all subjects. Phase shift values ranged from -75.8 to 78.9 degrees. The instability of phase shift (expressed as standard deviation) in control subjects (ranging from 2 to 13 degrees) was approximately half of the phase instability in patients with amblyopia. The last column of table 3.3 shows significance of difference in phase shift between the left and right eye. A plus sign represents a significant difference in phase shift between left and right eye. Significant differences have been observed in both patients and control subjects. No pattem could be detected in this variable with respect to wewing condifions and between groups.

Some measurements were repeated a few weeks after this experiment in four subjects $(J, 1, R$ and D). In one subject with micro-strabismus (D), different phase shifts were obtained but cyclovergence did not change. In the first experiment during binocular vision, subject D showed a large difference in phase shift between left and right eye of approximately 52 degrees. In the second experiment, the subject showed no difference at all: 1 degree with a standard deviation of 3 degrees. However, vergence stability was identical. This subject also showed an increased saccadic activity during pursuit in the second experiment.

\subsection{Discussion.}

In the present study, three-dimensional eye movements were investigated during horizontal smooth pursuit for monocular and binocular viewing conditions with scleral search coils. From these results five observations were made:

- Phase shift differences between horizontal and torsional eye movements were observed in both control subjects and in patients.

- In all patients, vertical vergence was most stable.

- In all patients, horizontal vergence stability depended on viewing conditions.

- Cyclovergence stability was lower in subjects with micro-strabismus than in nomal subjects.

- Cyclovergence and horizontal stability were lower in subjects with amblyopia than in normal subjects.

Several investigations were performed to exclude errors due to slippage of coils on the eyes. In our data, no slow torsional drift, which would indicate coil slippage (van Rijn, van der Steen et al. 1994; Straumann, Zee ot al. 1996), could be detected. Clear symmetries were found in phase shift and amplitude of torsion in both eyes of the control group. The latter result cannot be explained by coil slippage, since it would state that the amount of drift of the coils in both eyes is similar. This is not likely, due to the mirror symmetry of both eyes. Therefore, we conclude that a drift of the coils on the eyes did not cat use the observed phase shift and hysteresis.

\section{Phaseshift and hysteresis.}

In all subjects, small sinusoidally horizontal, verticall and torsional eye movements were observed during smooth pursuit. In controls, hysteresis values reached 2 degrees and phase shifts between horizontal and torsional eye movements ranged befween 0 and 60 degrees. Similar values were found in the literature (Ferman, Collewijn el al. 1987; Tweed, Fotter en al. 1992 and Westheimer and McKee 1973). Phase shifts observed in the experiment of Ott and Eckmiller (1989) were small, i.e. smaller than 21 degrees. The discrepancy, observed in phase shift between these studies might be due to the high inter-individual variation even in 
healthy subjects. since Ot and Eckmiller (1989) only calculated phase shifts in three subjects, they may have missed the phenomenon.

Donders' law states that cye movements are restricted to two degrees of freedom (Donders 1847). Listing's law explicitly describes how the eyes should rotate: all rotation vectors are bound to a iwo-dimensional plane, the so-called Listing"s plane (Helmholtz 1910). Hysteresis (and phase shift) between torsional and horizontal eye movements is a violation of both laws. Hysteresis is a path dependent phenomenon, specifically prohibited by Donders' law A phase shifi camnot be explained by a static rotation or tramslation of Listing planes: the amount of torsion has a linear relationship with horizontal amplitude. An excursion from Listing "s plane or, most unlikely, a slight continuous movement of the plane could only have caused the phase shift. However, the effect of the phase shift on perception was absent: none of the subjects remarked differences with respect to the orientation of the visual stimulus, when comparing binocular and monocular vision.

The validity of Donders' law during eye movements is still questioned. The opinion throughout investigators is divided in two groups: one group stating that Donders' law is violated during eye movements (e.g. Straumann, Zee et al. 1996), and the other that Donders' law still applies, however less strict than during static gaze situations (e.g. Collewijn, Ferman er at. 1988 and Tweed. Fetter et al. 1992). We tend to agree with the latter investigators. Donders" law is obeyed in during eye movements, but some playsiological parameters induce significant but small deviations during eye movements. The observed hysteresis and phase shift may have been caused by biomechanical factors at the plant: a combination of elasticity and viscosity of the oculomotor plant affect the velocity of eye movements. Skavenski and Robinson (1973), estimated phase shifts less than $45^{\circ}$ of horizontal eye movements caused by the mechanics of the orbit. An estimation of the amount of phase shift in torsional eye movements were not described. However, a small increase in phase shift compared to horizontal eye movements can be assumed, considering low elastic forces around the torsional axes (Simonsz, Crone et al. 1984).

In one of our subjects (D), after repetition of the experiment, a considerable difference was observed in phase shift between torsional and horizontal eye movements. In the methods sectron, we assumed a finear relationship berwen torsion and horizontal eye movements independent of head position. Howsver, our results suggest otherwise. Perhaps, due to a different position of the head, the orientation of the eye in head had changed: some muscles wore drawn tighter, while others were loosened. This could result in a change in phase shift.

\section{Vergence stability}

For optimal visual perception, retinal images need to correspond, within certain margins, on both retinas. In order to accomplish this, movements of both eyes are neuronally yoked (Hering 1868 and Tweed 1997). Correspondence prevents the perception of double images and allows full usage of stereopsis. As previous experiments have shown during fixation, absolute torsional position is less stable than torsional correspondence (Enright 1990 and van Rijn, van der Steen ef al. 1994). The results from our experiment confirm these findings. In all controls, cyclovergence movements were small (standard deviation $<0.5^{\circ}$ ). Viewing conditions did not influence the stability of these vergence eye movements. This may indicate that real-time visual feedback from both eyes is not essential for binocular coupling, during smooth pursuit, in normal subjects. 
In subjects with micro-strabismus without amblyopia, we found no significant difference in size of horizontal and vertical vergence stability compared to normal subjeots. Vertical vergence stability was highest, followed by horizontal vergence slability (van Rijn, ten Tusscher ef al. 1998). Torsional vergence was less stable than in controls. In our subjects with amblyopia we did find both horizontal and torsional vergence instability compared to nomal subjects. In a previous experiment, van Rijn, ten Tusscher ef al. 1998) investigetted vergence stability in subjects with micro-strabismus (and amblyopia) during fixation. These experiments showed increased vergence instability in all directions, compared to nomal subjects. Especially, horizontal vergence instability was higher than in normal subjects. From these results it is most likely to conclude that horizontal vergence instability is predominantly caused by amblyopia.

In all patients, horizontal vergence stability depended on viewing conditions. Van den Berg, van Rijn er al. (1995) and Melis, Cnysberg et al. (1997) showed that Listing's law applied in patients with strabismus and amblyopia, the orientation of the planes depended on the viewing condition. Bosman, ten Tusscher et al. (2001) [Chapter 4] additionally showed, that in patients with amblyopia and strabismus the planes were shaped abnomally and/or abnomally orientated. If both Listing planes are perfectly aligned, vergence instability is expected to be near zero. A shift or rotation of one or both planes could cause a change in vergence instability. Whether this is the case here could not be substantiated, since we could not calculate Lising planes from our data. Although the amount of subjects participating in the experiment and the observed variability does not allow us to make wide generalisations, we suggest another possibility: it is possible that vergence stability is controlled visually in subjects with strabismus. When these subjects look monocularly with their squinting bye, information of the periphery of the retina is mainly used where acuity is lower. In contrast to normal subjects, who apparently do not need visual feedback for binocular coupling of eye movements, real time visual feedback is essential in patients with strabismus during smooth pursuit. 


\section{5}

\section{References.}

Berg van den A.V. Rin van L.J. and Faber de J.T.J.H.N. (1995) Excess cyclovergence in paticnts with intermittent exotropia. Vision Res. 35, p.3265-3278.

Bosman I., ten Tusscher M.P.M., de Jong I., Vles J.S.H. and Kingma H. (2001) Listing's Law in Strabismus and Amblyopia, a Preliminary Report. In press: Strabismus

Collewin H., Ferman L. and Van den Berg A.V. (1988) The behaviour of human gaze in three dimensions. Ann. N.Y. Acad. Sci. 545, p.105-127.

Donders F.C. (1847) Beitrag zur Lehre von den Bewegungen des menschlichen Auges. Holländische Beiträge zu den Anatomischen und Physiologischen Wissenschaften 1, p.104145.

Enright J. (1990) Stereopsis, cyclotorsionat "noise" and the apparent vertical. Vision Res. 30 , p. 1487-1497.

Ferman L., Collewijn H. and Van den Berg A.V. (1987) A direct test of Listing"s law II. Human ocular torsion measured under dynamic conditions. Vision Res. 27, p.939-951.

Helmholtz H. (1910) In: von Kries J., Nagel W. (Eds.) Handbuch der Physiologischen Optik. Gullstrand A, 3rd ed, Hamburg, Leipzig, Voss Verlag.

Hering E. (1868) Die Lehre vom binocularen Sehen. Translated by Bridgeman B. \& Stark L. (Eds.), The theory of binocular viston. New York: Plenum.

Ivins J.P., Porrill J. and Frisby J.P. (1999) Instability of torsion during smooth asymmetric vergence. Vision Res. 39, p.993-1009.

Melis B.J., Cruysberg J.R.M. and van Gisbergen J.A.M. (1997) Listing's plane dependence on alternating fixation in as strabismus patient. Vision Res. 37, p.1355-1366.

Ot1 E. and Eckmiller R. (1989) Ocular torsion measured by TV-and scanning laser ophthalmoscopy during horizontal pursuit in humans and monkeys. Invest. Ophthalmol. Vis. Sci. $30,0.2512-2520$.

Rijn van L.J., van der Steen J, and Collewijn H. (1994) Instability of torsion during fixation: cyclovergence is more stable than cycloversion. Vision Res. 34, p. 1077-1087.

Rijn van L.J., ten Tusscher M.P.M., de Jong I. and Hendrikse F. (1998) Vergence stability in micro-strabismus. In. Lennersirand G (Ed) Advances in strabismology. Aeolus Press, Buren, p. $107-110$.

Robinson D.A. (1963) A method of measuring eye movements using a scleral search coil in a magnetic lield. IEEE Trans. Bioned. Eng., 10, p. $137-145$.

Robinson D.A. (1975) A quantitative analysis of extra-ocular muscle cooperation and squint. Invest. Ophthalmol. Vis. Sci. 14, p.801-\$25. 
Simonsz HJ., Crone R.A., de Waal B.J., Schooneman M. and Lorentz de Haas H.A.L. (1984) Measurement of the mechanical stiffness in cyclotorsion of the human eye. Vision Res. 24, p.961-967.

Skavenski A.A. and Robinson D.A. (1973) Role of abducens neurons in vestibuloocular reflex. J. Neurophysiol. 36, p.724-738.

Straumann D., Zee D.S., Solomon D. and Kramer P.D. (1996) Validity of Listing's law during fixations, saccades, smooth pursuit eye movements, and blinks. Exp. Brain Res. 112, p. 135146.

Tweed D., Fetter M., Andreaki S., Koenig E. and Dichans J. (1992) Three-dimensional properties of human pursuit eye movements. Vision Res. 32, p.1225-1238.

Tweed D., Misslisch H. and Fetter M. (1994) Testing models of the oculomotor velocity to position transformation. J. Neurophysiol. 72, 1425-1429.

Tweed D. (1997) Visual-motor optimization in binocular control. Vision Res. 37, p. 1939. 1951.

Westheimer G. and Mckee S.P. (1973) Failure of Donders' law during smooth pursuit eye movements. Vision Res. 13, p.2145-2153. 
Chapter 3

52 


\section{Chapter \\ 4}

\section{Listing's Law in Strabismus and Amblyopia.}

Bosman J., ten Tusscher M.P.M. ten, de Jong I., Vles J.S.H. and Kingma H.

Strabismus 2000, 8, p.157- 168 . 
We investigated whether Listing"s law applies in patients with diminished or no stereopsis, due to strabisimus or amblyopia. Eye mowements of normal subjects and patients with strabismus and/or amblyopia were registered during monocular and binocular fixation conditions; from these data shape and relative orientation of displacement planes were calculated. Within normal subjects, monocular or binocular fixation did not influence the thickness and relative orientation of displacement planes. No differences were found between normals and the patient with amblyopia due to anisometropia. In one patient with strabismus but without amblyopia, the orientation of displacement planes depended on fixation conditions; coupling between horizontal vergence effort and plane orientation was observed. Patients with amblyopia and strabismus showed abnormally shaped and/or abnormally oritentated displacement planes, which depended on fixation conditions. Also differences in shape of planes between both eyes were observed. These results show, that normal Listing behaviour can be present in subjects with diminished stereopsis. It also shows that normal stereopsis does not necessarily mean normal Listing bethaviour, suggesting that Listing's law is mainly a result of motor strategy. 


\subsection{Introduction.}

Eye movements can be described as rotations about three orthogonal axes in space: a horizontal, a vertical and a torsional axis. Donders (1847) discovered that when the head is fixated, every position of gaze is reached whith eye movements restricted to two degrees of freedom. In other words: when the torsional axis is set to coincide with the line of sight. the amount of torsion is unequivocally determined by the gaze direction and independent of previous eye movements. Helmholte (1910), formulated this even more specifically with the so-called "Listing"s law": "There exists a certain eye position from which the eye moy" reach any other position of faxation by a rotation arownd an axis perpendicular to the visual axis. This particular position is called "primary position" ". When using rotation vectors (see materials and methods), Listing's law states that all rotation vectors of one eye lie in a plane: the so-called Listing's plane. Only recently, Listing's law was extended binocularly, including vergence eye movements: during vergence eye movements and during elevation of fixation, Listing planes rotate in both eyes (Minken and van Gisbergen 1996; Mok, Ro et al. 1992 and van Rijn and van den Berg 1993).

As yet there is no generally accepted explanation for Listing's law. Previous investigations have shown that Listing's law appears to optimise ocular motor control and assist binocular vision in normal subjects (Minken and van Gisbergen 1996; Kapoula, Bernotas et al. 1999 and Tweed 1997). This motor strategy minimises three dimensional eye eccentricities from a resting position and prevents accumulation of torsion. Binocular vision is assisted, since the relative orientation of images projected on the retina of the two eyes depends on how both Listing planes are oriented. The eyes are controlled in such a way, that the images of both eyes can be fused by the brain to result in one image in depth. The oculomotor system appears to weigh both constraints, depending on the situation (Kapoula, Bemotas et al. 1999 and Tweed 1997). As a result, in most situations disparity is not eliminated, but merely reduced. However, the visual system in normal subjects has an error tolerance: perfect zeroing is not needed to obtain binocular vision.

In patients with strabismus, the eyes are not aligned normally and stereopsis is most often subnomal or absent. Therefore, less stability of eye movements is probably needed. Related to Listing's law, few experiments have been performed on patients suffering from eye movement disonders (van den Berg, van Rijn el al 1995 and Melis, Cruysberg ef al. 1997). These investigations have shown that both eyes of four patients with strabismus had Listing planes, howewer the orientation of the planes was abnormal: both planes were exorotated more than in normal subjects. The orientation varied depending on which eys was fixating. By investigating more patients with eye movement disorders, and with varying degrees of stereopsis, it might become clear to what extent binocularity depends on Listing "s law and vice versa. 


\subsection{Materials and methods.}

All experiments were performed following the tenets of the Declaration of Helsinki. Eye movements were recorded in ten subjects after giving informed consent, see table 4.1 .

Table 4. I. Subjects parlicipating in the experinent.

\begin{tabular}{|c|c|c|c|c|c|c|c|}
\hline Groups & Subj & Gender & Age & Deviating eye & \multicolumn{2}{|c|}{$\begin{array}{c}\text { Visual acuity } \\
\text { Left eye. Right eye }\end{array}$} & Stereopsis \\
\hline \multirow{4}{*}{ Controls } & $\pi$ & Male & 29 & - & $20 / 20$ & $20 / 20$ & $60^{\prime \prime}$ randiom dot \\
\hline & $T$ & Male & 29 & . & $20 / 20$ & $20 / 20$ & 60 "random dot \\
\hline & W & Male & 31 & - & $20 / 20$ & $20 / 20$ & $60^{\prime \prime}$ random doi \\
\hline & $Y$ & Female & 27 & - & $20 / 20$ & $20 / 20$ & $60^{\prime \prime}$ random dot \\
\hline $\begin{array}{l}\text { Amblyopia due to } \\
\text { anisometropia }\end{array}$ & I & Male & 31 & - & $20 / 100$ & $20 / 15$ & Positive Titmus fly \\
\hline \multirow{2}{*}{ Strabismus } & D & Male & 28 & Esoleft $<5^{9}$ & $20 / 20$ & $20 / 20$ & $460^{\circ}$ random dot \\
\hline & Du & Male & 57 & Exo right $25^{\circ}$ & $20 / 20$ & $20 / 20$ & $60^{\prime \prime}$ random dot \\
\hline \multirow{3}{*}{$\begin{array}{l}\text { Strabismus wilth } \\
\text { amblyopia }\end{array}$} & $R$ & Male & 38 & Eso left $<5$ & $20 / 25$ & 20180 & Positive Titmus fly \\
\hline & $A_{4}$ & Female & 56 & $\begin{array}{l}\text { Exo left } 12- \\
14^{0}\end{array}$ & $20 / 20$ & 20130 & Diplopia \\
\hline & $\mathrm{Ra}$ & Female & 68 & Eso left $29^{1 / 2}$ & $20 / 25$ & 20180 & Posilive Titmus fly \\
\hline
\end{tabular}

\section{Recording rechmiques.}

Three-dimensional eye movements were recorded using the scleral search coil technique (Robinson 1963) (Skalar, Delft, The Netherlands). Prior to each experiment, gain and offset of the coils were calibrated using a gimbals calibration device placed near the centre of the coil system. Digitisation was performed using a $12-$ bit ad-converter $\left(+40^{\circ}\right)$ at 200 Hz. The data from the measurements were used in a matrix transformation described by Ferman, Collewijn el al.(1987) for correction of coil misalignment and of non-linearity"s between coil voltages and rotation angles. All data were examined for coil slippage by checking for slow chrift in the torsion signal of the coils over a period of approximately 20 seconds according to the procedure described by van Rijn and van den Berg (1993).

\section{Probocol and vismat shimulus.}

Subjects were seated on a stool in a dimly lit room at the centre of the coil system with the thead restrained by a chin and forehead rest. The stimulus consisted of a rectangular matrix of 9 coloured dots on a plain white wall, 2 meters away from the subject. The diameter of the dots was $2 \mathrm{~cm}$ and the horizontal and vertical angular separation between dots was \pm 10 degrees of visual angle, resulting in eye movements within a range of 14 around the straight-ahead direction. The experiment consisted of three measurements of approximately 30 seconds each. Subjects were asked not to blink during recordings since during blinks, eye mowements do not obey Listing's law strictly (Ferman, Collewijn et a. 1987). During each experment, the subject fixated each dot for approximately 3 seconds starting and ending at the centre point. In each experiment, subjects were fixating under Nhee conditions: binocularly, right eye only and left eye only. The subjects obtained monocular vision by means of a hand-held oecluder. For each patient with strabismus, this procedure was repeated at least once. 
Dota anatysis.

All eye rotations were expressed in a head-fixed coordinate system using rotation vectors (Haustein 1989). As a result, no head movements were allowed: a head movement would be interpreted as an eye movement, thus disturbing the measurements. Figure 4.1 presents an illustration of a rotation vector system. In a coordinate system using rotation vectors, eye positions are described as rotations from a reference position to the current position... The $x$-axis of this co-orlinate system points forwards, the $y$-axis leftwards and the $z$-axis upwards. Torsional, vertical and horizontal eye positions are specified by $x, y$ and $z$ respectively. A lefward rotation of the eye corresponds to a dot on the qy axis, upward rotation at dot on the $q_{z}$ axis.

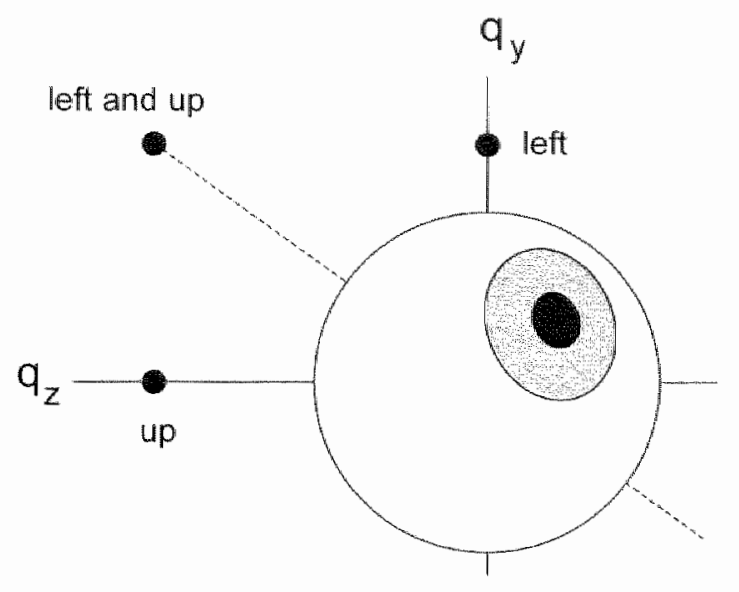

Figure 4.1. Whistration of a motarion vector system.

Each eye position is described by a rotation vector $\bar{q}$ :

$$
q=\left(q_{x}, q_{y}, q_{z}\right)=\tan \left(\frac{\alpha}{2}\right) m
$$

in which $\alpha$ is the amount of rotation about unit vector $\bar{n}$. By inverting formula 1 , all data can be expressed in degrees, symbolising a rotation from the reference to the instantaneous position.

If Lising's law holds perfectly, all rotation wectors should be confined to a lat plane (Helmholtz 1910). The best-fit plane to these data is called the displacement plane (Tweed, Cadera ef al. 1990 and Haslwanter 1995). The orientation of this plane depends on the reference position, defined as the straight-ahead position (direction of gaze towards the centre dot in the fixation matrix). In this experiment, the orientation of the fitted plane is calculated in relation to the straight-ahead position (middle target point).

We included only data points before and 0.5 seconds after a gaze shift (saccade), since during a saccade perception is interrupted and Listing's law is obeyed less (Feman, Collewijn et al. 1987). The displacement plane was calculated using a least squares fit to the data using two algorithms. Figure 4.2 a shows a flat surface fit using a first-order equation, while Figure $4.2 \mathrm{~b}$ shows a wisted surface fit using a second-order equation. 


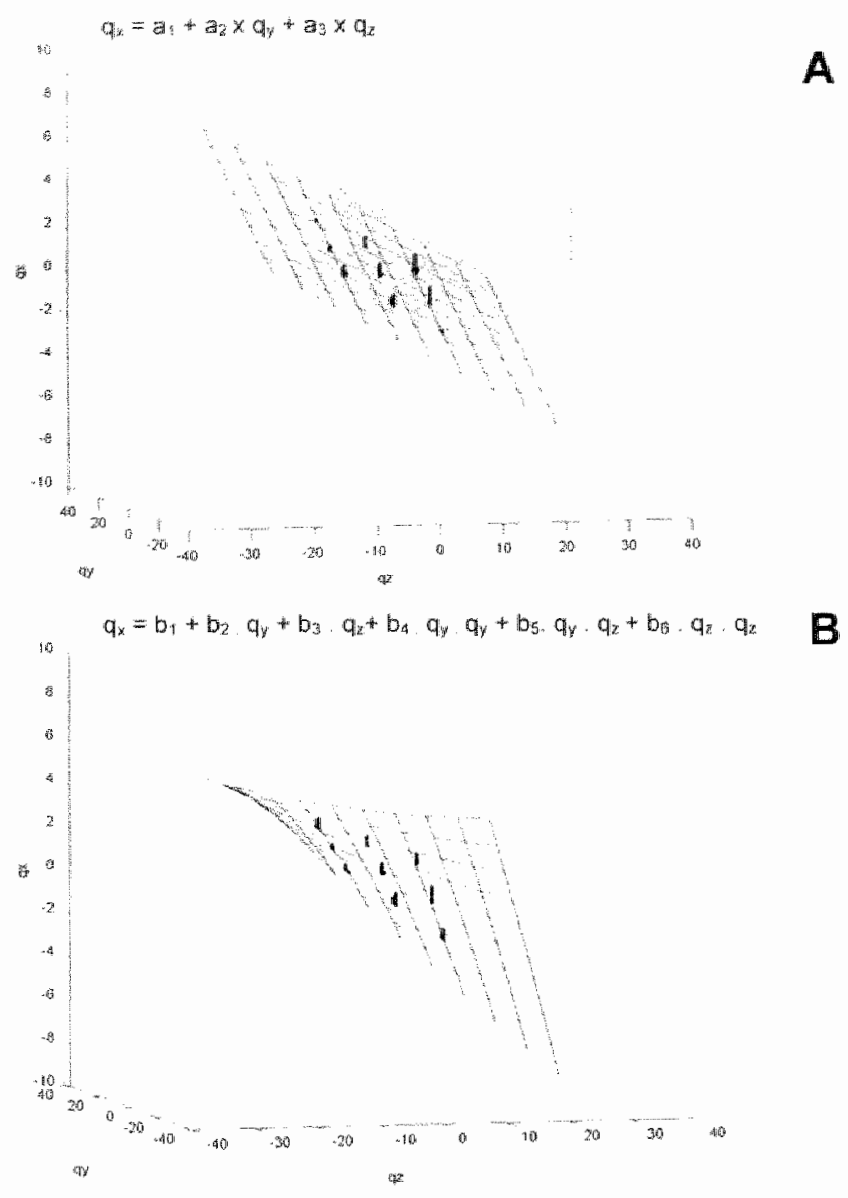

Figure 4.2. Fitring Al flat suface and B) curved surface to the same data. Black dots represent fixation points in rotation vectors in degrees. In the formulas. $q$ is the rotation vector as described in formulal.

The coeflicients of these equations were obtained by minimising the scatter of data in the torsional direction. This procedure also calculated the standard deviation of the data about the fitted surface in the direction of $q_{x}$.

We focused on three aspects in these equations:

- thickness of the surface by means of the standard deviation of the data about the lited flat surface in torsional direction.

- orientation of the flat surfaces. The relative orientation of the planes is clescribed as the angle between the surfaces of the right and left eye. The horizontal and vertical angle between both planes is called respectively yaw tilt difference (YTD) and pitch tilt difference (PTD). When YTD and PTD are both $0^{\circ}$, the planes of both eyes are parallel.

- a quantitative measure of the amount of twist of the surface. In figure $2 b$, the coefricient $b$; represents the amount of twist of the plane Desouza, Nicolle et al. 
1997). A twist factor of zero corresponds to a non-twisted surface (as is to be expected when the eye follows Listing"s law).

The values between subject groups were compared using a non-parametric Mann-Whitney test. All reported p-values are calculated assuming two-sided alternative hypothesis and significance was assumed when $p \leq 0.05$.

\subsection{Results.}

\section{Shape of the planes.}

No slow torsional drift due to coil slippage was observed. First the shape of the displacement planes in all. subjects was considered by fitting a flat surface in all data points. Thickness of the planes (also representing goodness-of-fit) for all fixation conditions is summarised in Figure 4.3 . In these plots the plane thickness of each eye is presented as the standard deviation of the data about the fitted surface in torsional direction. The results of all normal subjects were averaged.

The average thickness of the planes of both eyes in all fixation conditions for all normal subjects was $0.43 \pm 0.11^{0}$. In nomal subjects, no significant difference in plane thickness was found between fixation conditions and between both yes. The patient with amblyopia due to anisometropia (I) showed no significant difference in plane thickness compared to the normal subjects. Averaged values of patients with strabismus without amblyopia (D, Du) also showed no significant difference compared to normal subjects. However, plane thickness of one patient (Du) was approximately twice as thick compared to nomal subjects during binocular fixation. Patients with strabismus and amblyopia ( $R, A$ and $R a)$, showed an increase in plane thickness in both eyes compared to normal subjects when fixating monocularly (Mann-Whitney: $\mathrm{p}<0.03$ ). The average of both monocular fixation conditions in these patients was: right eye fixating $0.9 \pm 0.5^{0}$ and left (affected) eye fixating $1.5 \pm 0.7^{t}$. Especially patient $A$ showed values up to 4 times higher than normal subjects. In the same group, a significant difference was observed in plane thickness between both cyes (Wilcoxon: $\mathrm{p}=0.05$ ) in the binocular fixation condition. The average thickness of the affected eye was $1.13 \pm 0.65^{\circ}$ and of the normal eye $0.76 \pm 0.35^{\circ}$. In one patient (R) the plane of his affected left eye was approximately $t^{0}$ thicker than of his right eye. 

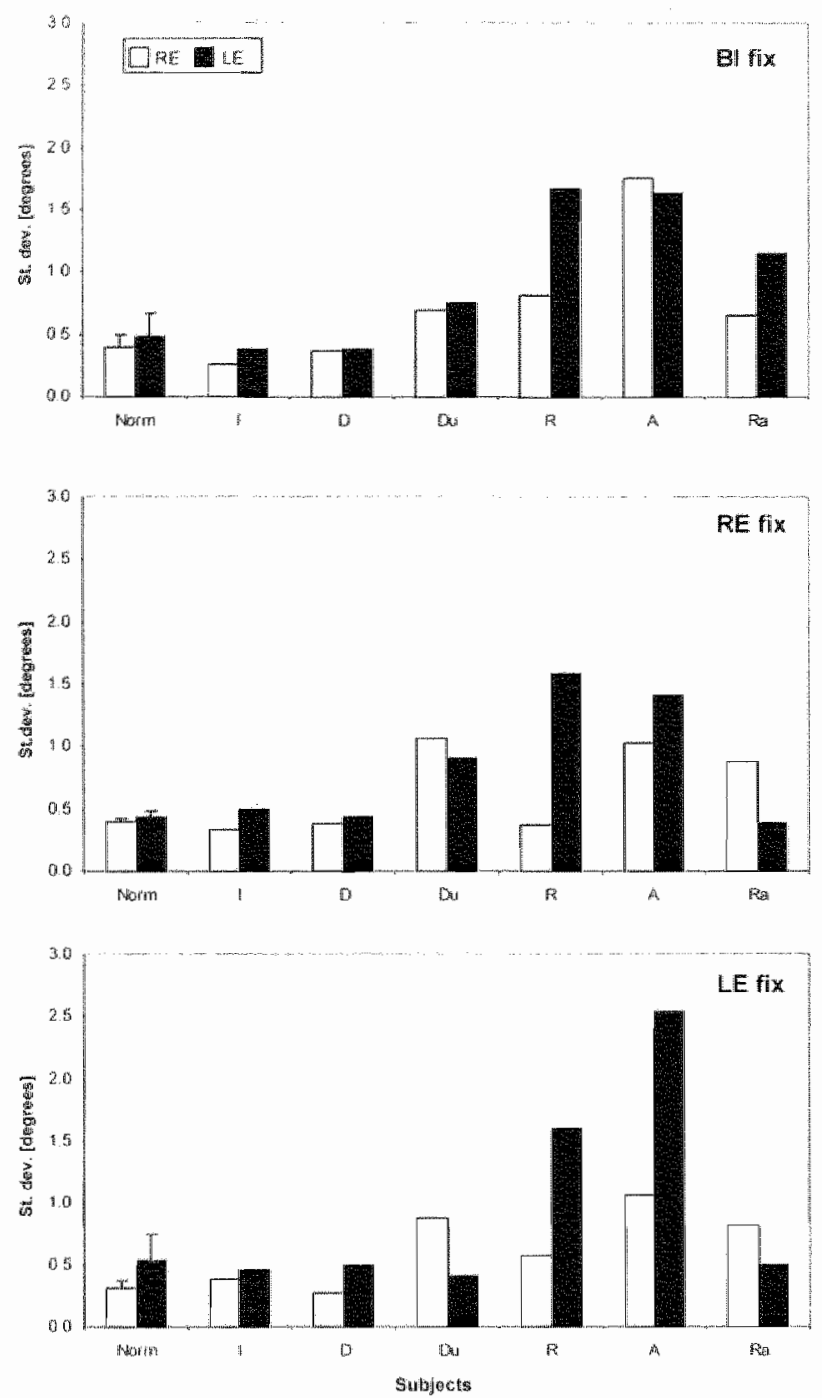

Figure 4.3. Thickness of the displacement planes presented as the standard denation of the data whout the fited surface in rorsional direction. Each plot whow the thickness of each eye of the subjects in all fixation conditions: binocular (bi), whit gye (re) and left eye (le) fixation. Nomal subjects (norm) were averaged, error bars represent one standard deviation. In all patients with strabismws, the average of mo measurements was iaken. 

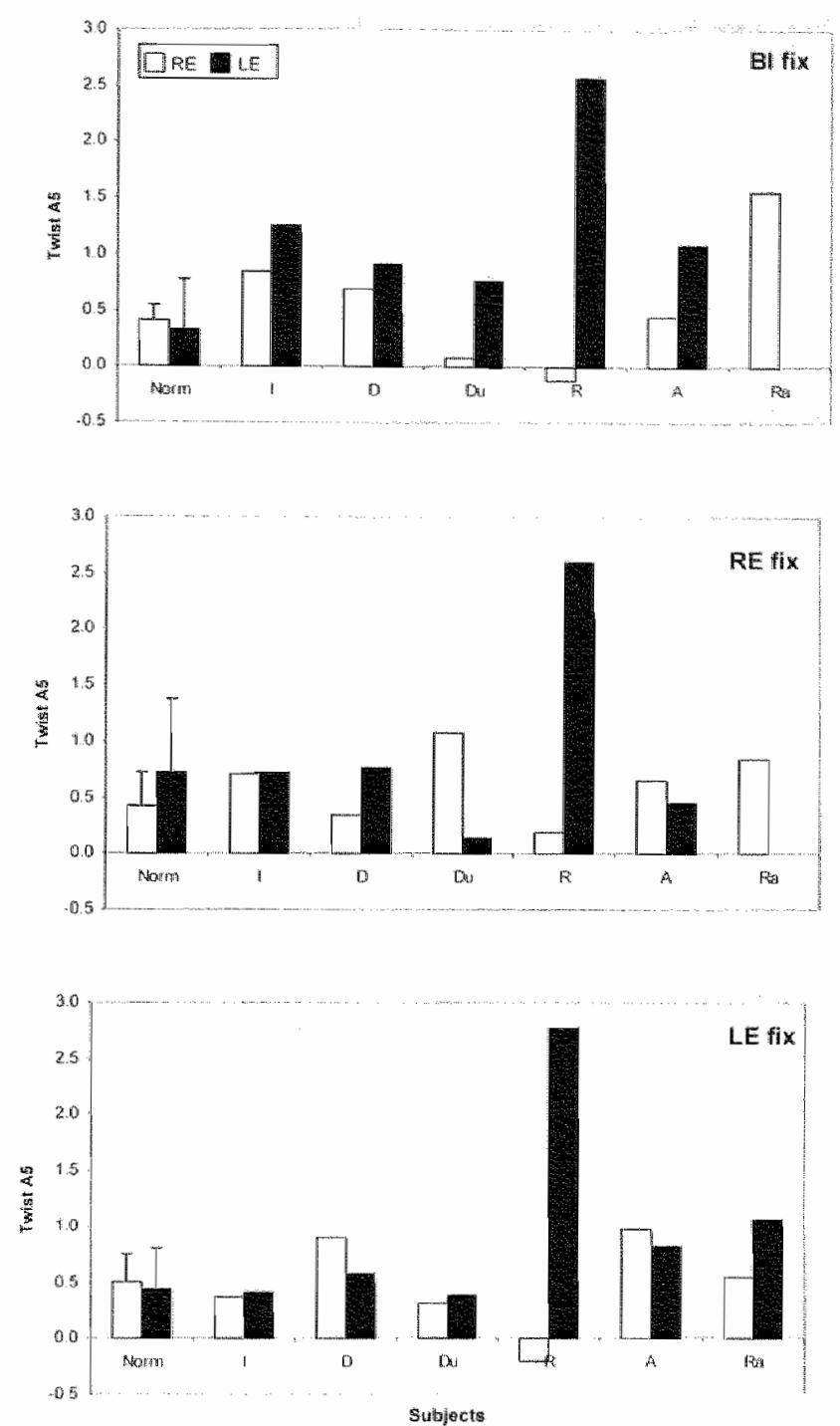

Figure 4. 4. The wist of the displacement planes (and Listing's planes) presented as the twist factor (bs in figure 4.2b). Each plor shows the rwist of each eye of the subjects in all firation conditions: binocular (bifix). right eye (re fix) and left oye (te fix) fixation. In patients with strabismus, the average of two measurenents was taken?

Twist of the planes was determined after a curved surface was fitted to the data. Figure 4.4 shows the twist factors of each subject in all fixation conditions. Twist data from patient Ra's right eye were removed in the binocular and left eye fixation conditions. Horizontal and vertical eye movements from this eye were small, approximately half the amplitude of horizontal and vertical movements of the right eye, resulting in an inaccurate fit of the 
twisted surface. Fitting a flat surface is less sensitive to this error, therefore the thickness of the plane was not removed from this subject.

All subjects showed some twist in their displacement planes. No significant difference was found between fixation conditions and between both eyes in all subjects. The average twist value of both eyes and all fixation conditions in nomal subjects was $0.48 \pm 0.36$. Also no significant difference was found between patient groups and nomal subjects. One patient $(\mathbb{R})$ showed a large difference in twist of the displacement plane between both eyes in all measurements (difference of 2.5 ).

\section{Relative orientation of the planes.}

Figure 4.5 summarizes pitch tilt difference (PTD) and yaw tilt difference (YTD) for the different fixation conditions.
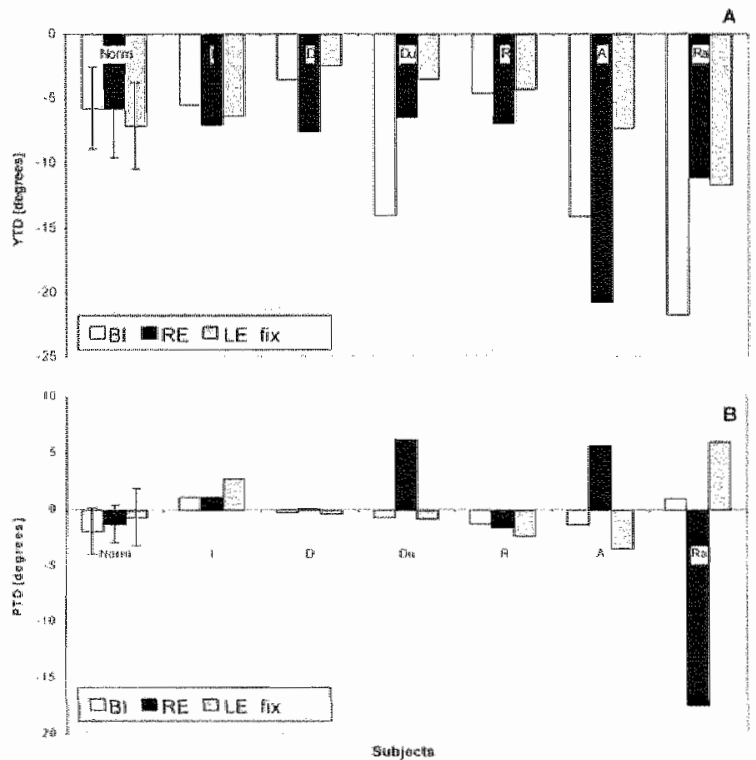

Figure 4.5. Angle between displacenent planes while observing fargess at 2 metres distance in all fixation conditions: binocular (bifix), right eye (re fix) and left eye (le fix) fixation. A) pitch tilf difference (PTD) and B) yaw tilt difference (YTD) defined as right minus left plane orientarion. A negative yaw represents an eroratation of the planes.

The average PTD value in nomal subjects was $1.3 \pm 2.1^{0}$. The average YTD in normal subjects over all fixation conditions was $-6.1 \pm 3.5^{\circ}$. Fixation conditions did not infuence the average angle between both planes in either direction. Mam-Whitney tests showed no significant difference in YTD and PTD between patients and normals, probably caused by the small number of subjects. Some patients (Du, A and Ra) showed some interesting features. Patient Du had intermittent exoiropia. When the patient fixated binocularly, the eyes were not squinting, whereas during monocular fixation the left eye dewiated approximately $25^{\circ}$. The YTD values in this patient, also varied between fixation 
conditions: the planes were approximately $10^{\circ}$ more exorotated when the patient is fixating binocularly than during monocular fixation. The squint angle of patient A (exotropia and amblyopia) also varied between tixation conditions: the squint angle increased by $8^{0}$ when fixating monocularly. During binocuar fixation, the eyes were not aligned sufheienty since the patient had diplopia. The YTO angles between fixation conditions varied between $-7^{\circ}$ and $-21^{\circ}$. Patient Ra's (esotropia and amblyopia) squint angle did not vary between fixation conditions, however extremely large walues and variations were observed in YTD and PTD: PTD values ranged from $-17^{\circ}$ to $6^{\circ}$ and YTD values from $-22^{\circ}$ and $-11^{\circ}$.

\subsection{Discussion.}

\section{Shape of the planes.}

The average thickness of the planes of both eyes in all fixation conditions of notmal subjects was $0.43 \pm 0.11^{13}$. This value is somewhat smaller than observed in previous experiments: e.g. Melis, Cruysberg et af.(1997) found 0.69 $0.19^{0}$. Haslwanter, Curthoys et af.(1994) $0.8 \pm 0.2^{\text {it }}$ and Straumann, Haslwanter ef al.(1991) $1.4 \pm 0.5^{\circ}$. This difference is probably due to different measurement and task conditions. Our subjects made cye mowements within a range of $14^{i}$ around the straight-ahead direction, whereas for instance the subjects in Straumann, Haslwanter of al. (1991)and Melis, Cruysberg et al.(1997) made eye movements in the range of respectively $25^{\circ}$ and $35^{\circ}$. Patients with strabismus without amblyopia showed diferent results: of these two patients, only one obeyed Listing's law strictly. Our patients with strabismus and amblyopia showed an average thickness of 0.94 $0.5^{0}$ in the normal eye and $1.5 \pm 0.7^{0}$ in the amblyopic eye during monocular fixation. Although these values were in the same range as the values observed in the literature, they were significantly higher than in our normal subjects. We therefore conclude that Listing"s law is obeyed to a lesser degree in all patients with strabismus but one (D). This is supported by the results of Van den Berg, van Rijn et al. (1995) who also found a $25 \%$ increase in plane thickness in three strabismic patients.

In all subjects, some twist in displacement planes was observed (average of 5 nomal subjects was $0.48 \pm 0.36$ ). No significant difference was found between fixation conditions and between both eyes in all subjects. This value was slighly higher than observed in previous experiments: Glenn and Vilis (1992) found $0.18 \pm 0.11$ and Desouza, Nicolle or al. (1997) 0.24 10.11 . However, the impact is still very small: if a subject with a twist factor of 0.48 would look $10^{17}$ horizontally and $10^{\circ}$ vertically, a torsion of $0.4^{\circ}$ is measured.

\section{Orientation of the planes.}

The average PTD value in normal subjects was $1.3 \pm 2.1^{1}$. This value agrees with previous imvestigations (Tweed $\mathbb{1 9 9 7}$ and Mikhael, Nicolle ef al (1995), where also values close to zero were found. The average YTD in normal subjects over all fixation conditions was $6.1 \pm 3.5^{\prime \prime}$ (=lemporally rotated). Fixation conditions did not influence the average angle between both planes in either direction. Previous investigations have shown a wide variation of YTD values when subjects fixated real targets at 2 meters distance: Mok, Ro et al. (1992) found values of a few degrees, Mikhael, Nicolle et al.(1995) $5.5^{\text {th }}$ nasal to $9.8^{\circ}$ temporal and Bruno and van den Berg (1997) an average value of 5 temporal. So far, the results' discrepancies have been attributed to differences in experimental procedures and 
idiosyncrases belwen subjects (Bnuno and van den Berg 1997). In normal subjects, the relation between wergence and YTD has been studied extensively: a vergence eye movementi causes both displacement planes to exorotate. Quantitatively there are still some differences (Minken and van Gisbergen 1996; Mikhael, Nicolle et al.1995 and Bruno and van den Berg (1997). Rotation of displacement planes due to vergence was smallest in Mikhae, Nicolle er al (1995): YTD equals 0.72 times the convergence angle. If we assume that the expected YTD value is $0^{\circ}$ at 2 meters in normal subjects, and the vergence angle is approximately $2^{6}$, then a YTD value of $-20^{67}$ would be expected at a convergence angle of 28 , i.e. when fixating a target at $13 \mathrm{~cm}$. If we repeat the calculation with values of van Minken and wan Gisbergen (1996) and Bruno and wan den Berg (1997), the expected vergence angle would be slightly smaller.

One patient (Du) had a divergent squint angle of $25^{\circ}$ when fixating monocularly; during binocular fixation the squint angle was zero. We observed a negative YTD value of $-14^{0}$ when he was fixating binocularly. During monocular fixation, YTD values became closer to zero: approximately $-5^{0}$. This patient appeared to follow the model proposed by Van den Berg, van Rijn er al. (1995). It was shown that in patients with exotropia, cyclovergence was. linked to horizontal vergence effort wather than to eyes' convergence angle. During binocular lixation, the patients made an effort to align both eyes, whereas during monocular fixation the effort was absent. When the vergence effort was highest, the planes were exorotated most. In patient D we did not observe abnormal YTD angles. This patient had a small squint angle $\left(<5^{5}\right)$, if there was an effect it was probably too small to observe.

In all patients with strabismus and amblyopia, the squint angle hardly changed between fixation conditions. Since they had very limited sensory fusion, the effort to align both eyes, as normal subjects do, was absent. Nevertheless, patients $\mathrm{A}$ and Ra both showed large wariations in YTD values. Patient $R$, who only had a minimal squint, did not show this behaviour: his plane orientations were similar to normal subjects. Patient A's divergent squint angle was smaller compared to patient Du, however both planes were exorotated more: the angle was $-15^{\circ}$ during binocular fixation, during monocular fixation the angle between both planes became $-20^{\circ}$. It would appear that both control of vergence and plane orientation are completely absent in this patient. Patient $R a$, who had a converging squint angle of $29^{\circ}$ showed large variations in YTD values: ranging from $-21^{\circ}$ to $-12^{\circ}$. In nomal stubjects, an $\mathrm{YTD}$ or $-20^{\circ}$ is expected ${ }^{19}$ at a convergence angle of $28^{\circ}$. The squint angle of paticnt $\mathbb{R a}$, when fixating a distant target, was $29^{\circ}$, similar to the expected vergence angle. This offset in vergence angle and not the efrort as was mentioned by van den Berg ef al could justify the YTD values in these patients. The relation does not appear to be very strict, since latge variations (approximately $10^{\circ}$ ) in YTD occurned between fixation conditions.

Stereopsis and Listing "s law.

Listing's law is not obeyed strictly in patients with strabismus. Especially patients with strabismus and amblyopia violated Listing"s law: displacement planes are thicker and the orientation is incorrect. Although we did not measure the orientation of the planes at differant fixation distances, it is clear that accurate control of vergence and orientation of the planes is absent. This was also found by Melis, Cruysberg et al. (1997) in one patient with strabismus and amblyopia. In our experiments, eye movements of subjects with. varying degrees of stereopsis have been recorded. No clear relation was found between loss of stereopsis and the shape and relative orientation of the displacement planes. 
Listing's law may be obeyed without the presence of stereopsis and nomal stereopsis does not necessarily mean normal Listing behaviour. This suggests that Listing "s law is mainly a consequence of motor strategy.

\subsection{References.}

Berg van den A.V., Rijn van L.J. and Faber de J.T.J.H.N. (1995) Excess cyclovergence in patients with intermittent exotropia. Vision Res. 35, p. 3265-3278.

Bruno P. and Berg Van den A.V. (1997) Relative orientation of primary positions of the two eyes. Vision Res. 37, p.935-947.

Desouza J.F.X., Nicolle D.A. and Vilis T. (1997) Task-dependent changes in the shape and thickness of Listing's Plane. Vision Res. 37, p.2271-2282.

Donders F.C. (1847) Beitrag zur Lehre von den Bewegungen des menschlichen Auges. Holländische Beiträge zu den Anatomischen und Physiologischen Wissenschaften 1, p.104145.

Ferman L., Collewijn H. and Van den Berg A.V. (1987) A direct test of Listing's law II. Human ocular torsion measured under dynamic conditions. Vision Res. 27, p.939-951.

Glenm B. and Vilis T.(1992) Violations of Listing's law after large eye and head gaze shifts. J. Neurophysiol. 68, p.309-318.

Haustein W.(1989) Considerations on Listing's law and the primary position by means of a matrix description of eye position control. Biol. Cybern. 60, p.411-420.

Haslwanter T. (1995) Mathematics of three-dimensional eye rotations. Vision Res. 15 , p. $1727-1739$.

Haslwanter T., Curthoys I.S., Black R. and Topple A. (1994) Orientation of Listing's plane in nomals and in patients with unilateral vestibular deafferentation. Exp. Brain Res. 101, p.525528.

Helmholtz H. (1910) In: von Kries J., Nagel W. (Eds.) Handbuch der Pllysiologischen Optik. Gullstrand A, 3rd ed, Hamburg, Leipzig, Voss Verlag.

Kapoulla Z., Bemotas M and Haslwanter T. (1999) Listing's plane rotation with convergence: role of disparity, accommodation, and depth perception. Exp. Brain Res. 126, p. 175-186.

Melis B.J., Cruysberg J.R.M. and van Gisbergen J.A.M. (1997) Listing's plane dependence on alternating fixation in a strabismus patient. Vision Res. 37, p.1355-1366.

Mikhael S., Nicolle D. and Vilis T. (1995) Rotation of Listing"s plane by horizontal, vertical and oblique prism-induced vergence. Vision Res. 35, p.3243-3254.

Minken A.W. and Gisbergen van JA. (1996) Dynamical version-vergence interactions for a binocular implementation of Donders' law. Vision Res. 36, p.853-867. 
Mok D. Ro A. Cadera W. Crawford J.D. and Vilis T. (1992) Rotation of Listing's plane during wergence. Vision Res. 32, p.2055-2064.

Rijn van L.J., Berg wan den A. (1993) Binocular eye orientation during fixations: Listing's Law extended to include eye vergence. Vision Res. 33, p.691-708.

Robinson D.A. (1963) A method of measuring eye mowements using a scleral search coil in a magnetic field. IEEE Trans. Biomed. Eng., 10, p.137-145.

Straumann D., Haslwanter T., Hepp-Reymond M.C. and Hepp K. (1991) Listing's law for eye, head and arm movements and their symergetic control. Exp. Brain Res. 86, p.209-215.

Tweed D. (1997) Visual-motor optimization in binocular control. Vision Res. 37, p.19391951.

Tweed D., Cadera W. and Vilis T. (1990) Computing three-dimensional eye position quatertions and eye velocity from search coil signals. Vision Res. 30, p.97-110. 


\section{Chapter}

\section{5}

The Influence of Eye Muscle Surgery on Shape and Relative Orientation of Displacement Planes: Indirect Evidence for Neural Control of 3D-Eye Movements

J. Bosman, M.P.M. ten Tusscher, I. de Jong, J.S.H. Vies and H. Kingma.

Submitted for publication. 
Is Listing s law a consequence of $2 \mathrm{D}$ control of eye positioning, where eye torsion is determined by biomechanical properties of the orbita or is it a reflection of full $3 \mathrm{D}$ neuronal control? This was investigated by observing the influence of a radical change of mechanical properties of the eye plant on $3 \mathrm{D}$ eye movements. Shape and relative orientation of displacement planes were measured using sicleral coils before and after operation of 5 patients with strabismus. The operation influenced the shape of displacement planes in both eyes of all patients. After the operation, most patients obeyed Listing's law more accurately: a monocular orbital change caused binocular improvements of torsional control. The relative orientation of planes also changed, however no clear relationship was found between the type of operation and the direction of rotation. These results show, that Listing's law is not just a result of biomechanical properties of the eye plant, but has a neural basis. 


\subsection{Introduction.}

Listing's law states that when the head is fixated, all eye positions can be reached from a reference position by rotations about axes that lie in a plane, called displacement plane (Helmholtz 1910). If no torsion is observed from an eye centered view, the reference position is called primary position and the plane is called Listing's plane. Since the arrival of scleral search coils (Robinson 1963) many researches have investigated the validity of this law. It was shown that the law holds well for fixations and fairly well during smooth pursuit fixations (e.g. Tweed, Fetter et al. 1992) and saccades (Tweed and Vilis 1990). However, the law is violated during the vestibulo-ocular reffex (Crawford and Vilis 1991) and during sleep (Nakayama 1975). What is the purpose of Listing"s law? Two of the most important reasons are: the optimisation of ocular motor control and assistance of binocular vision (Minken and van Gisbergen 1996; Tweed 1997 and Kapoula, Bernotas ef al 1999). Motor strategy minimises three dimensional eye eccentricities from a resting position and prevents accumulation of torsion. Binocular vision is assisted, since the relative orientation of images projected on the retina of the two eyes depends on how both Listing planes are oriented. The eyes are controlled in such a way, that images of both eyes can be fused by the brain to result in one image in depth. Only until recently, the law was extended to include binocular eye movements (Mok, Ro et al. 1992 and van Rijn and van den Berg 1993). In normal subjects, the planes rotate during vergence eye movements and elevation of gaze.

So we know it is there and we can even imagine why it must be there. But how is it implemented? This question is still cause of debate in literature. Is Listing's law a consequence of biomechanical properties of the orbita (Schnabolk and Raphan 1994; Demer, Oh et al. 2000 and Quaia and Opticam 1998) or is it completely controlled neuronally? (Tweed, Fetter et al. 1992) The main difference between these two approaches is whether positioning of the eyes is controlled neuronally in two (horizontal and vertical) or three (horizontal, vertical and torsional) dimensions. Schnabolk and Raplan (1994) have suggested that the brain drives the eyes two dimensionally toward a fixation object, without worrying about the forsional orientation of the eyes; torsional positioning of the eyes is thus considered purely a consequence of biomechanical factors of the orbital plant. Demer, Miller et al.(1995) enthanced the model by adding so-called muscle pulleys. Wilh these pulleys, the model was able to predict Listing plane behaviour (Quaia and Optican 1998). In a three-dimensional model (Tweed 1997 ) the brain is completely responsible for Horizontal, vertical and torsional positioning of the eyes. In this model the brain controls torsion to both optimise ocular motor control and to assist binocular vision (Minken and van Gisbergen 1996; Tweed 1997 and Kapoula, Bernotas el al. 1999). The oculomotor system appears to weigh both constraints, depending on the situation (Tweed 1997 and Kapoula, Bernotas ef al. 1999). For instance, during the vestibulo-ocular reflex, binocular vision is of no importance and all eye movements are optimised for motor control.

The goal of this study is to investigate the influence of a radical change of mechanical properties of the eye on shape and relative orientation of Listing"s planes. By obscrving eye movements in patients before and after squint operations we studied the influence of a change of mechanical properties within the orbit of one eye on the orientation and shape of displacement planes in both eyes.

Only a few articles describe Listing's law in patients with eye movement disordars (van den Berg, van Rijn van et al.1995; Melis, Cruysberg et al.1997 and Bosman, Tusscher ten, et al. 2000). It was shown that patients with amblyopia and strabismus obey Listing's law, allhough 
to a lesser degree than normal subjects: the planes are abnomally shaped and/or abnormally orientated, depending on the fixation condition. Also differences in shape of planes between both cyes have been observed. The influence of a strabismus operation on Listing's planes has only been investigated ones. Haustein (1988) described a change in orientation of the operated eye of three patients before and after recession of one of the oblique muscles. Within a few weeks after the operation the orientation nomalized again.

If Listing's law were mainly the result of motor strategy, then the operation would have a large influence on three-dimensional positioning of the eye, since the mechanical properties of the eye muscles have been altered radically. Therefore the shape of displacement plane of only the operated eye is expected to change radically. The relative orientation of the planes should also change specific to the operation. For example, operation of subjects with exotropia resulls in a convergent eye movement. In normal subjects this movement results in an exorotation of displacement planes (Mok, Ro el al.1992 and van Rijn and van den Berg 1993). In these patients we expect to find a shift in the same direction.

\subsection{Materials and methods.}

\section{Subjects participating in the experiment.}

All experiments were performed following the tenets of the Declaration of Helsinki. Each patient gave informed consent after the explanation of the experiment. The patients were measured respectively 2 weeks before and 6 weeks after the operation.

Patient A was a 56 years old female with consecutive exotropia, with restriction of eye movements. She underwent two prior operations in 1965 and 1998 for convergent squint. Ophthalmic examinations showed visual acuity of $20 / 20$ in the right eye (RE) and 20/30 left eye (LE). Before the operation she had -12 degrees of exotropia, with diplopia (double vision) in straight ahead position and right gaze. Operation: LE $5 \mathrm{~mm}$ resection medial rectus, $2 \mathrm{~mm}$ recession lateral rectus. After the operation the squint angle was +2 degrees, slne had no diplopia and a positive Titmus ny.

Patient $B$ was a 23 years old female with Brown syndrome RE with secondary strabismus sursoadductorus. She underwent two prior operations in 1997 and 1998, both a recession of the superior oblique. No stereoacuity due to double vision. Ophthalmic examinations showed normal visual acuity: RE $20 / 20$ and LE $20 / 20$

Operation: RE $9 \mathrm{~mm}$ recession inferior oblique

Patient D was a 57 years old male, with intermittent exotropia. He underwent two prior operations in 1984 on the right eye. Ophthalmic examinations showed visual acuity of $20 / 20$ in both eyes. Before the operation the exotropia was -25 degrees, after the operation -3 degrees. Operation: LE $7 \mathrm{~mm}$ recession of the lateral rectus and $6 \mathrm{~mm}$ resection medial rectus. Stereoacuity was subnomal before and after the operation (both TNO 120").

Patient $L$ was a 50 years old male with a 4 th nerve paresis of the left eye. He underwent five prior operations in 1989,1990 and 1994 . Ophthalmic examinations showed a visual acuity of RE $20 / 20$ and LE $20 / 20$ and no stereopsis. Operation: transposition medial recti (both eyes!). 
Parient $R$ was a 68 years old female with esotropia without any prior operitions. Ophthatmic examinations showed a visual acuity of RE $20 / 20$ and LE 20/30. Before the operation the squint angle was 29 degrees, with downshoot in adduction RE. Operation: RE 5 mm medial recession, $6 \mathrm{~mm}$ lateral resection and $10 \mathrm{~mm}$ superior oblique recession. After the operation the squint angle was 10 degrees.

Note: The operation was performed on the right eye, which is the dominant eye of this subject.

\section{Materials.}

Three-dimensional eye movements were recorded using scleral search coils (Skalar, Delf, The Netherlands). Prior to each experiment, gain and offet of the coils were calibrated using a gimbals calibration device placed near the centre of the coil system. Digitisation was performed using a 12 -bit ad-converter $\left( \pm 40^{3}\right)$ at $200 \mathrm{~Hz}$. The data from the measurements were used in a matrix transformation described by Ferman, Collewijn $\mathrm{ct} a$. (1987) for correction of coil misalignment and of non-linearity's between coil voltages and rotation angles. Subjects were seated on a stool in a dimly lit room at the centre of the coil system with the head fixated by a bite-board and forehead rest. The following stimulus was used: a matrix of 20 coloured dots on a plain white wall 1.8 meters away from the subject. The diameter of the dots on the wall was $2 \mathrm{~cm}$ ( 10.5 degress visual angle) and the maximum distance of the dots from the centre was \pm 20 degrees horizontally and vertically. An experiment consisted of 3 measurements where the subjects fixated the dots on the wall. The subject fixated each dot for approximately 3 seconds starting and ending at the centre point. The experiment was performed with three fixating conditions: binocularly, right eye only and left eye only. Monocular vision was obtained by means of a hand-held occluder. Subjects were asked not to blink during recordings.

\section{Data analysis.}

A detailed description of the analysis of shape and orientation of displacement planes can be found in Bosman, ten Tusscher ef al. (2000). All cye rotations were expressed in headfixed, co-ordinates system using rotation vectors (Has/wanter 1995). In this system, eye positions are described as rotations from a reference position to the current position. The $x$ axis of this co-ordinate system points forward, the $y$-axis leftward and the z axis upward. Torsional, wertical and horizontal eye positions are specified by $x, y$ and $z$ respectively.

If Listing's law holds perfectly, all rotation vectors should be confined to a flat plane (Helmholtz 1910) called displacement plane (Tweed, Caclera ef al. 1990 and Haslwanter 1995). The orientation of this plane depends on the reference position. In this experiment, the orientation of the fitted plane is calculated in relation to the straight-ahead position (middle target point). We included only data points before and 0.5 second after a gaze shift (saccade). The shape of the displacement plane was calculated using a least squares fit to the data. The thickness of the plane was determined by calculating the standard deviation of the data about a flat plane. By fitting a surface, the curvature of the displacement plane was calculated (Desouza, Nicolle et al. 1997). The curvature of a plane is represented by one variable: the twist factor (Desouza, Nicolle et al 1997). A twist factor of zero corresponds to a non-twisted (i.e. flat) surface (as is to be expected when the eye follows. Listing's law). 
Finally, the relative orientation of the planes was determined. The relative onentation of the planes is described as the angle betwen the flat displacement planes of the right and left eye. The horizontal and vertical angle between both planes is called respectively yaw tillt difference (YTD) and pitch till difference (PTD). When YTD and PTD are both $0^{\circ}$, the planes of boh eyes are parallel.

To compare results between before and after the operation a 2 -related non-parametric statistical test was performed (Wilcoxon). All reported p-values are calculated assuming twosided allemative hypothesis and significance was assumed when $p \leq 0.05$.

\subsection{Resulls.}

Shape of displacement planes.

Figure 5.1 shows an example of displacement planes of the affected eye of patient $D$. This example shows that the shape of displacement plane before the operation is curved more than after the operation.

Prevperative

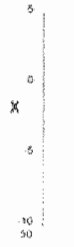

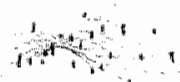

Post-pperative

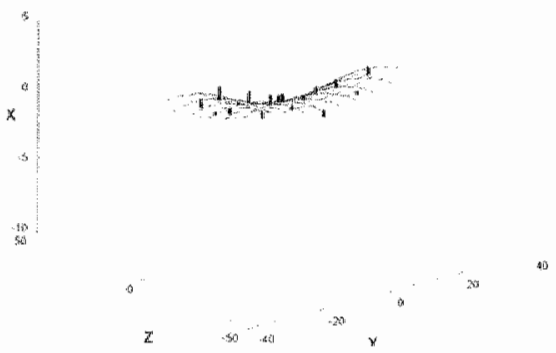

Figure 5.1. Displacemen plane of the affected eye during binocular fuation of patient D before and after the operation. The shape of the plawe has nomalized afler the operation. Valnes ane in degrees.

Thickness and twist of displacement plane of all patients before and after the operation are depicted in Figure 5.2.

Before the operation, average plane thickness of all our patients was $1.32 \pm 0.5^{5}$ (average of both eyes and all fixation conditions). Statistical tests showed only a significant decrease of wist in both eyes, when subjects (except L) were fixating monocularly with the operated eye (Wilcoxon p 0.05 ). When subjects were looking with their non-operated eye or binocularly, the decrease is visible especinlly for twist, however it was not significant. 


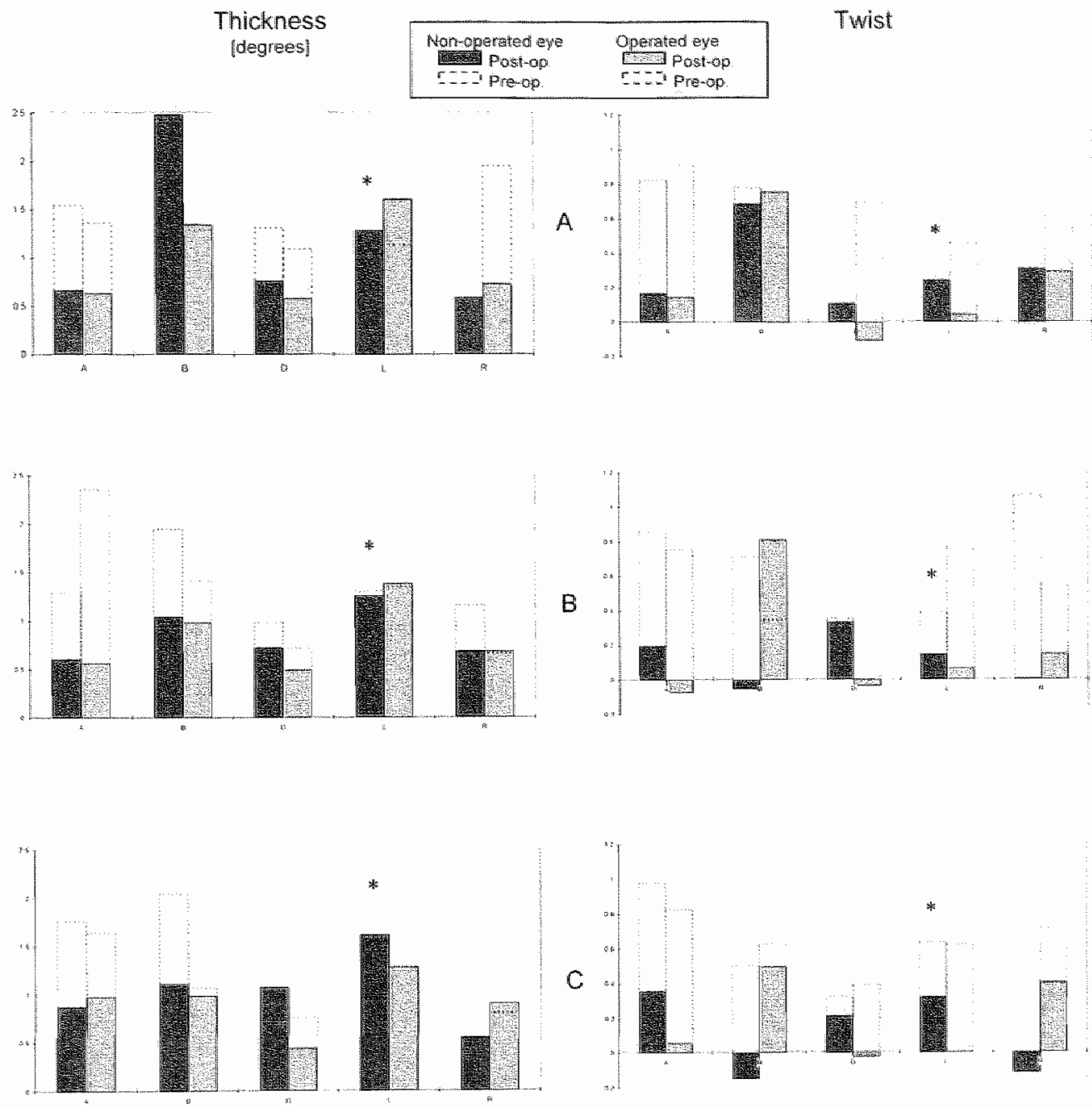

Figure 5.2. Thickness [degrees] and wist of displacement plane of all patient. Three fration conditions: A) binocular, B) monocalar with the non-operated eye (mon) and C) monocular with the operated ye (op). Dotted lines are before the operation. Patient L was operated on boh eyes.

Orientation of displacement planes.

Yaw and pitch angle were determined of the displacement planes. Figure 5.3 shows the results pre- and post-operative. Statistical tests showed no significant difference between pre- and post-operative yaw and pitch angles (Wilcoxon $\mathrm{p}>0.1$ ). 


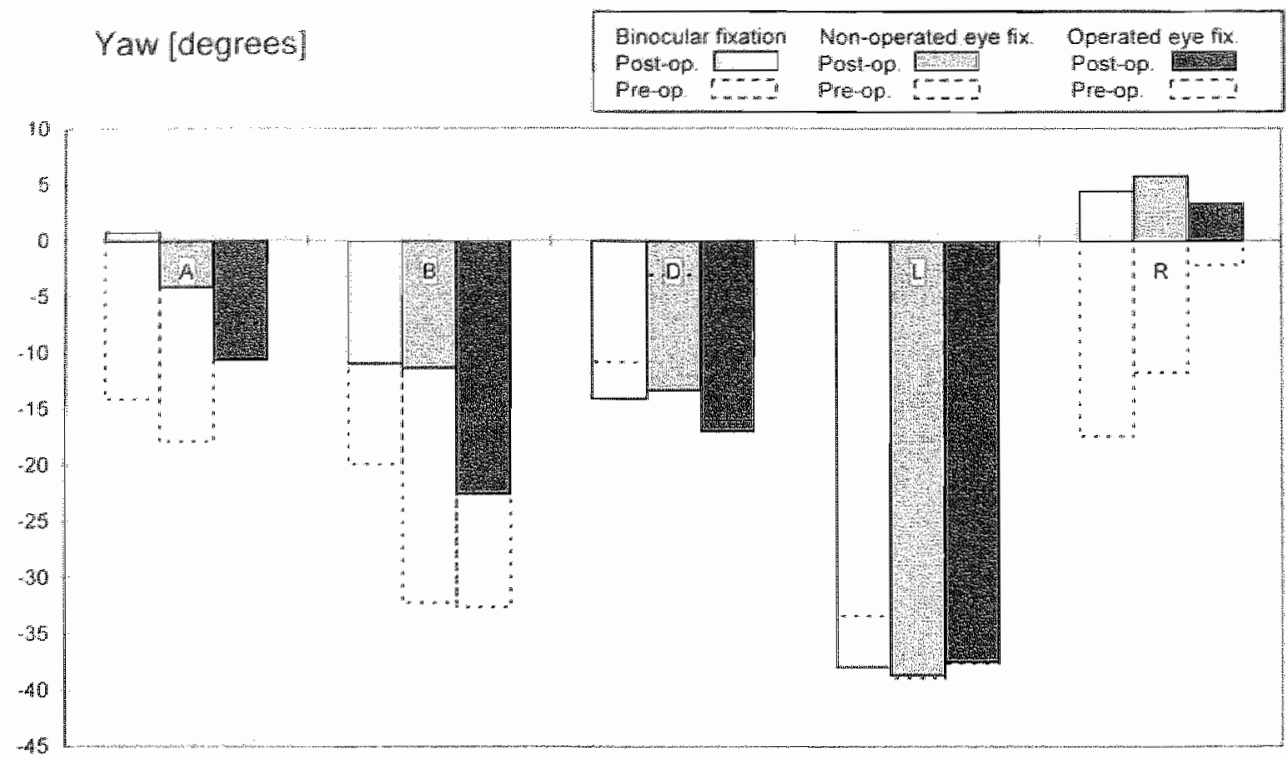

Pitch [degrees]

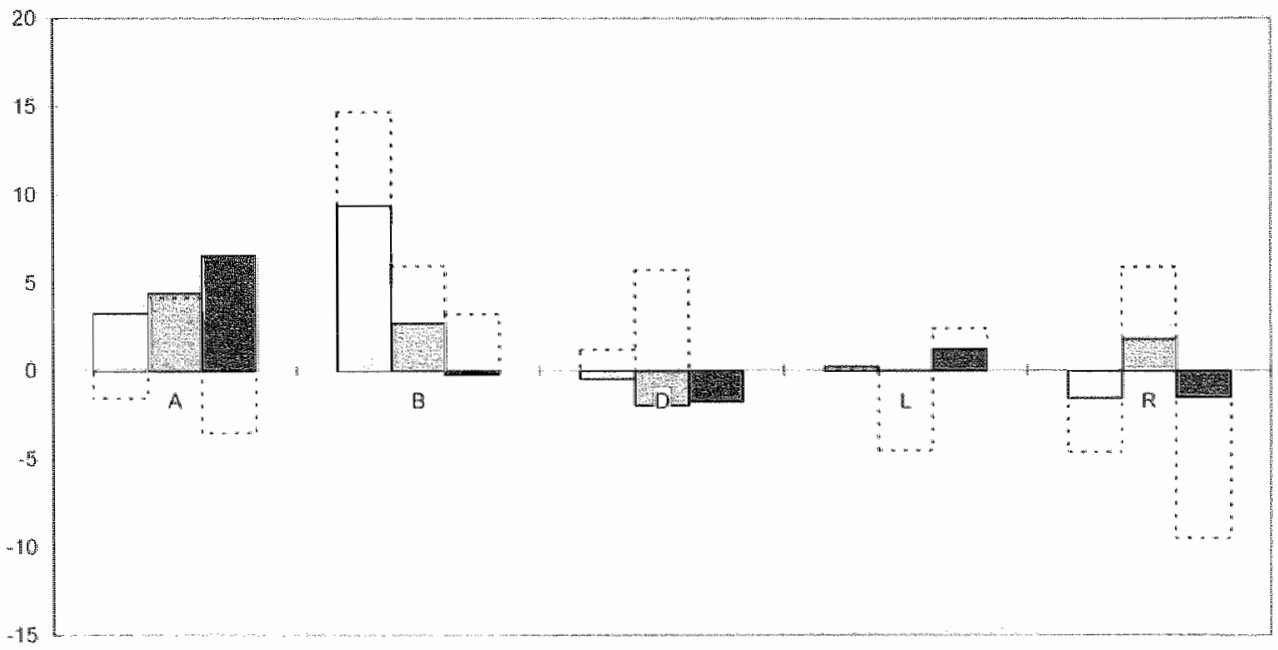

Figure 5.3. Relative orienation of displacenen planes, yow and pitch angles in degrees. Binocular" (bi), non-operated cye (non) and operated eye (op) foxation condition, before (pre) and afier (post) the operation. * Patient L was operated on botheyes. 


\subsection{Disscussion.}

\section{Shape of the pianes.}

Before the operation, average plane thickness in our patients was $1.32 \pm 0.5^{\text {taverage of both }}$ eyes and all fixation conditions). This result is thee times higher compared to nomal subjects observed in a previous experiment (Bosman, ten Tusscher ef al. 2000). Under almost similar experimental conditions we found, that the average plane thickness in nomal subjects was $0.43 \pm 0.11^{\circ}$. The only difference between these two experiments was the size of fixation matrix. The subjects in the present experiment fixated a matrix twice as large. By fixating an larger matrix and more points, the accuracy of fitting a surface to the data increases. The increase in plane thickness in our patients compared to normal subjects contirms the results of Melis, Cruysberg et al. (1997) and Van den Berg, van Rijn er al. (1995). These studies showed, in a total of 4 patients with strabismus, that plane thickness was significantly higher compared to normal subjects and depended on fixation conditions. In the present experiment before the operation, twist values varied considerably between patients and between both eyes: from -0.1 to 1.1 . The impact of twist factor of 1.1 (patient $R$ ) is considerate: if the subject looks $20^{\circ}$ to the right and $20^{\circ}$ up, torsion becomes $4^{0}$. Previous investigations found twist values ranging from $0.18 \pm 0.11$ (Glenn and Vilis 1992) to $0.48 \pm 0.36$ (Bosman, ten Tusscher et al. 2000) in normal subjects. Before the operation, both thickness and twist of the displacement plane in these patients were higher compared to nomal subjects, indicating that Listing's law is obeyed to a lesser degree in both eyes.

Statistical tests overall showed non-significant differences between before and after the operation due to the small amount of subjects and high inter-subject variability. However the data suggests that six weeks after the operation, four out of live patients ( $A, D, R$ and $L)$ obeyed Listing's law more accurately than before. In patient $\mathbb{B}_{\text {p }}$ the changes in twist and thickness were small and uncorrelated. In all patients who were operated nonocularly, the quantitative changes in thickness and twist in the operated eye were similar to the changes in the non-operated eye. The most important aspect of these results is, that after the operation in three patients both eyes obeyed Listing's law more accurately, where only one eye was operated on.

\section{Orientation of the planes.}

Previous investigations showed an average PTD value in normal subjects elose to zero (Mikhael, Nicolle et al. 1995. Tweed 1997 and Bosman, ten Tusscher et al. 2000). YTD walues when subjects fixated real targets at 2 meters distance showed large variations: Mok at al. (1992) found values of a few degrees, Mikhael, Nicolle et al. (1995) $5.5^{63}$ nasal to $9.8^{6}$ temporal and Bruno and van den Berg (1997) an average value of 5 temporal. So far, the results" discrepancies have been attributed to differences in experimental procedures (Minken, van Gisbergen er al. 1996) and idiosyncrasies between subjects (Bruno and van den Berg 1997). PTD in our subjects was before the operation, averaged over all fixation conditions 1.3 $\pm 5.9^{\prime \prime}$ and after the operation $1.5 \pm 3.3^{\prime \prime}$. These results fall well within the range of normal subjects. The YTD angles however, are not in the same range as normal subjects. While fixating a target at 2 meters, YTD angles of $-35^{\circ}$ are shown. The results will be discussed for each subject individually: 
- Patient D. In a prevous experiment (Van den Berg, van Rin et al. 1995 ) it was shown that in patients with exotropia, cyclovergence was linked to horizontal vergence effort rather than to eyes ${ }^{3}$ convergence angle. During binocular fixation, the patients made an cfron to align both eyes, whereas during monocular fixation the effort was absent. When the vergence effort was highest, the planes were exorotated most. Before the operation patient $D$ had al divergent squint angle of $27^{\circ}$ when fixaring monocularly; during binocular fixation the squint angle was zero. We observed a negative YTD value of $14^{4}$ when he was fixating binocularly. During monocular fixation, YTD values were closer to zero: approximately $-5^{0}$. This result was already shown in a previous study (Bosman, ten Tusscher et al. 2000). After the operation, YTD values in all fixation conditions were similar to the binocular fixation condition before the operation. The operation reduced the squint angle, by rotating the affected eye inwards. This convergence eye movement of approximately $23^{\circ}$ resulted in an exorotation of displacement planes of $13^{\mathrm{b}} \mathrm{in}$ the monocular fixation condition. This is comparable to the rotation of displacement planes in normal subjects during vergence (Minken and van Gisbergen 1996; Mikhae,, Nicolle et al. 1995 and Bruno and van den Berg 1997). For instance Mikhael, Nicolle ef al. (1995) showed that YTD equals 0.72 times the convergence angle. In this subject the multiplication factor was 0.6 . Patient $A$, also had exotropia prior to the operation. YTD values varied considerably $\left(110^{\text {ih }}\right.$ ) between fixation conditions. After the operation, the squint angle had reduced to 2 degrees. The orientation of the planes changed too: during binocular and monocular fixation with the dominant eye the planes were more parallel (esorotation of $\pm 14^{6}$ ) and were slightly more exorotated (with $3^{\text {g }}$ ) during monocular fixation with the affected eye than before the operation. The esorotation is completely opposite to the result of patient $\mathrm{D}$, who had a similar operation. This suggests that the orientation of the planes is not just a result of mechanical properties of the eyes. If this were the case, then two identical operations would at least result in a rotation of displacement planes in similar directions.

Patient $R$. The operation of patient $R$ reduced the esotropia of the left eye with $19^{6}$ and esorotated the displacement planes. In normal subjects this would happen when the eyes make a divergence movement. In this subject, the planes have rotated as would hawe been expected in a nomal subject; the operation has induced a divergence eye movement and the planes have rotated accordingly. However, the amount of rotation is 100 large. A divergence cye movement of $20^{\circ}$ would induce an esorotation of $\pm 14^{6}$ (Mikthael, Nicolle et al. 1995 ) in a nomal subject; in this patient this was $21^{\circ}$ during binocular fixation. After the operation, differences in PTD and YTD between fixation conditions have reduced.

In palient $\mathrm{B}$ the oblique inferior muscle of the right eye has been recessed. This operation reduces the amount of excyclotorsion of the eye. Theoretically, we would not expect a change in PTD or YTD, however we observed an exorotation of YTD of approximatelly $10^{\circ}$.

Although both eyes of patient $L$ were operated, the relative orientation of displacement planes remained unchanged.

\section{Liwings law: newrat or bionechanical?}

All paticnts obeyed Listing's law fairly accurate independent of the fact whether the subjects had none or normal stereopsis, or whether the squint angle prior to the operation was small or large. The operation influenced the shape of displacement planes (and thus the threedimensional eye movements) in both eyes of all patients. After the operation, most patients 
obeyed Listing's law more accurately. monocular orbital change caused binocular improvements of torsional control. If Listing's law were purely the result of bionechanical properties of the eye plant, no changes would have been observed in the non-operated wo. This also goes for the pulley model, as was mentioned by Dener, Oh er al. (2000) The operation performed in our patients leaves the pulleys intact but changes the orientation of one eye relative to the pulleys. This might have an effect on three-dimensional ey movements of the operated eye, but not on those of the non-operated eye. Additionally, we expected that identical operations would have comparable effects on the shape and orientation of the planes. However, in two patients, who underwent identical operations, the direction of rotation of displacement planes was opposite. These results show, that Listing's law is not just a result of biomechanical properties of the eye plant, but has a neural basis.

In this experiment we investigated the patients two weeks before and six weeks after the operation. It would be of interest how the three-dimensional eye movements change throughout the first weeks and months after the operation. In his experiment, Haustein (1988) has shown, that the orientation of the displacement plane of the affected eye gradually changes (normalizes) within a few weeks. Furure experiments should investigate the shape and orientation of the displacement plane of each eye throughout this period. This should give us a better insight in the central processes involved in three-dimensional control of eye movements. 


\subsection{References.}

Berg van den A.V., Rijn van L.J. and Faber de J.T.J.H.N. (1995) Excess cyclovergence in patients with intermittent exotropia. Vision Res. 35, p.3265-3278.

Bosman I. Tusscher M. P. M. ten, Jong I. de \& Kingma H. (2000) Listing's law in strabismus and amblyopia. Strabismus, 8, p. $157-168$.

Bruno P. and Berg Van den A.V. (1997) Relative orientation of primary positions of the two eyes. Vision Res. 37, D.935-947.

Crawford J.D. and Vilis T. (1991) Axes of eye rotation and Luisting"s law during rotations of the head. J. Neurophysiol. 65, p.407-423.

Demer J.L., Miller J.M., Poukens V., Vinters H.V. and Glasgow B.J. (1995) Evidence for fibromuscular pulleys of the recti extraocular muscles. Invest. Ophthalm. \& Visual Sci. 36 , p. $1125-1136$.

Demer I.L., Oh S.Y. and Poukens V. (2000) Evidence for Active Control of Rectus Extraocular Musle Pulleys. Invest. Ophthalm. \& Visual Sci. 41, p.1280-1290.

Desouza J.F.X., Nicolle D.A. and Vilis T. (1997) Task-dependent changes in the shape and thickness of Listing's Plane. Vision Res. 37, p.2271-2282.

Ferman L., Collewijn H. and Van den Berg A.V. (1987) A direct test of Listing's law JI. Human ocular torsion measured under dynamic conditions. Vision Res. 27 , p.939-951.

Glenn B. and Vilis T.(1992) Violations of Listing's law after large eye and head gaze shifts. J. Neurophysiol. 68, p.309-318.

Haustein W. Die Steurung des Auges unter Listings Gesetz: Ein Matrizen-modell der Okulomotoric und die Rolle der visuellen Reafferenz. PhD Thesis 1988, Technische Universität München, Germany.

Has/wanter T. (1995) Mathematics of three-dimenstonal ye rotations. Vision Res. 15, p. $1727-1739$

Helmholtz H. (1910) ln: von Kries J., Nagel W. (Eds.) Handbuch der Physiologischen Optik. Gulstrand A, 3rd ed, Hamburg. Leipzig, Voss Verlag.

Kapoula Z., Bernotas M and Haslwanter T. (1999) Listing's plane rotation with convergence: role of disparity, accommodation, and depth perception. Exp. Brain Res. 126, p.175-186.

Melis B.I., Cruysberg J.R.M. and van Gisbergen J.A.M. (1997) Listing's plane dependence on alternating fixation in a strabismus patient. Vision Res. 37, p. $1355-1366$.

Mikhael S., Nicolle D. and Vilis T. (1995) Rotation of Listing's plane by horizontal, vertical and oblique prism-induced vergence. Vision Res. 35, p.3243-3254.

Minken A.W. and Gisbergen van JA. (1996) Dynamical version-vergence interactions for a 
binocular implementation of Donders' law. Vision Res. 36, p.853-867.

Mok D., Ro A., Cadera W., Crawford J.D. and Vilis T. (1992) Rotation of Listing's plane during vergence. Vision Res. 32, p.2055-2064.

Nakayama K. (1974) Photographic determination of the rotational state of the eye using matrices. Am-J-Optom. Physiol. Opt, 51, p.736-742.

Quaia C. and Optican L.M. (1998) Commutative saccadic generator is sufficient to control a 3-D ocular plant with pulleys. J. of Neurophysiol. 79, p.3197-3215.

Rijin van L.J., Berg van den A. (1993) Binocular eye orientation during fixations: Listing's Law extended to include eye vergence. Vision Res. 33, p.691-708.

Robinson D.A. (1963) A method of measuring eye movements using a sclerd search coil in at magnetic field. IEEE Trans. Biomed. Eng., 10, p.137-145.

Schnabolk C. and Raphan T. (1994) Modeling three-dimensional velocity to position transformation in oculonotor control. J. of Neurophysiol. 71, p.623-638.

Tweed D., Cadera W. and Vilis T. (1990) Computing three-dimensional eye position quaternions and eye velocity from search coil signals. Vision Res. 30, p.97-110.

Tweed D. \& Vilis T. (1990). Geometric relation of eye positions and velocity vectors during saccades. Hision Research, 35, 691-708.

Tweed D., Fetter M., Andreaki S., Koenig E. \& Dichans J. (1992). Three-dimensional properties of human pursuit eye movements. Vision Res. 32, p. 1225-1238.

Tweed D. (1997) Visual-motor optimization in binocular control. Vision Res. 37, p. 1939 1951. 
Chapters 


\section{Chapter}

\section{6}

A binocular 2D-video eye tracker for babies using the corneal reflection-centre of pupil technique.

J. Bosman, I. de Jong, H. Kingma, J.S.H. Vles and M.P.M. ten Tusscher.

Submitted for publication. 
A system is described to measure binocular eye movements wh one video camera placed at 2.5 meters from the subject. The system uses the corneal reflex-bright pupil technique to register horizontal and vertical eye movements. Due to the non-intrusive and easy set-up eye movements of both adults and small infants (babies) can be measured. The results of the system were compared to simultaneous eye movement measurements with scleral search coils in one healthy subject. During steady fixation both systems showed a slight spread in datapoints: the video system showed a standard deviation of $\pm 0.3^{\circ}$ horizontally and $\pm 0.6^{\circ}$ vertically compared to $\pm 0.1^{\circ}$ in both directions when measured with scleral search coils. The correlation coefficient between both systems is 0.98 horizontally and 0.95 vertically. 


\subsection{Introduction}

Only four months after birth are babies capable of almosi all eye movements such as smooth pursuit and saccades (Hainline, Riddell ef al. 1992; von Hofsten and Rosander 1997 and Jacobs, Harris er al 1997). Binocular control (i.e. vergence and version) also develops in this period. If accurate binocular control does not develop properly in these first few months, sensory binocularity (i.e. the ability to fuse images of both eyes) will not develop in the intant (Blakemore 1976 and LeVay, Wiesel ef al 1980 ). Several other oculomotor disorders also originate from these first few months after birth, eg strabismus and amblyopia (Rouconx. Culee et al 1983). There has been much research on the development of perception and control of eye movements in infants. These measurements were perfomed either monocularly or binocularly with very low sampling rates $(\angle 4 \mathrm{~Hz}$ ) by using pholographic techniques. No accurate measurements have been performed to investigate the development of temporal and spatial characteristics of binocular fixations in babies. In order to assess the development of binocular fixations in babies, a new apparatus was developed using the bright pupil comeal reflection technique. This manuscript describes a system that is able to detect point of regard of both eyes online, with an accuracy smaller than $1^{\circ}$ and a sampling rate of $25 \mathrm{~Hz}$ in both adults and small infants.

\subsection{System demands}

There exist a great number of different techniques of measuring direction of regard, every system with its own advantages and disadvantages. A list of demands was made in order to decide which measurement technique could be used to measure binocular fixations of babies 2-3 months after birth and small infants.

- no attachments to the head

- no rigid fixation of body or head

- last setup and measurement due to the limited time of attention of the infant

- small head movements should not influence the accuracy

- only the visual stimulus, should attract the attention of the infant

- measurement of horizontal and vertical eye movements, with an accuracy of $<1$.

- visual attractive stimulus, moveable to different distances from the subject

In an arricle by Young and Sheena (1975), a comparison was made between seven different techniques to measure eye movements. Since the article, no revolutionary new developments occurred in measurement techniques, therefore the article was a good guide in the decisionmaking. Most of these methods (stch as the scleral search coil system, head-mounted comeal rellection or video-oculographic techniques, Purkinje eye trackers and limbus boundary systems) require rigid immobilization of the head or they require that subjects carry an apparatus on the head. These requirements are inappropriate for work with small infants: infants do not allow restraints or placement of apparatus on the head. Elfectro-oculography (or electro nystagmography) is a system that is often used with small infants. However, the system is not capable of measuring vertical cye movements accurately, and regular recallbration is necessary to cancel out drift in the signal. The only system that meets the requirements is the comeal rellection method (e.g. Merchant 1969) and Hialh 1969). This technique meastres direction of regard by using infrared light reflections on the scanning eye rellated to the centre of the pupil. An ordinary ced-camera can be used to acquire the images. The commercially available systems that use this principle had wo major disadvantages. The first one being that all available systems worked monocularly. The second disadvantage was 
the very thigh price approximately $\$ 25.000$. In order to work binocularly, wo systems should have been bought. Therefore the decision was made to develop an improved binocular concal reflecion - pupil centre system ourselves.

\subsection{Principle of comeal reflection-centre of pupil.}

An infrared light source is algned with the camera axis. Infrared (IR) light is being used since it is invisible to the subjects but not to the camera. The collimated light rays reflected from the retina back to the camera make the pupil appear brighter than the surrounding eye and face (Figure 6.1). The light source also appears as a small bright spot reflected back from the front surface of the eye (the comeal reflex). If the optic axis of the eye happens to be aimed directly toward the camera, the reflected spot will appear to be located right in the centre of the pupil. In other circumstances, the displacement of the spot from the pupil centre will be a function of the degree to which the optic axis is turned away from the camerallocation. Thus, measures derived from the centre of the pupil can indicate the momentary direction of gaze. This is not exactly true because the fovea is slightly displaced from the optic axis of the eye (by several degrees). However, since the effect remains constant, this error can be neglected (Bronson 1983).

\section{Side view}
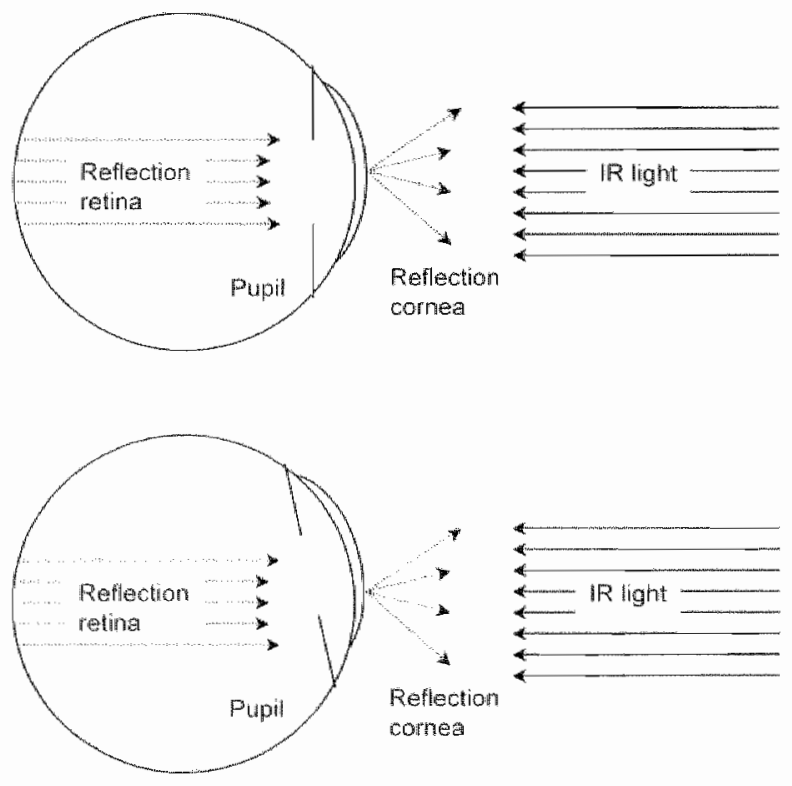

\section{Front view}
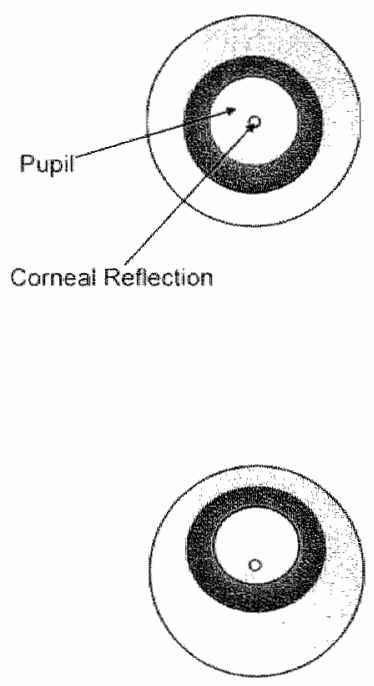

Figure 6.1. Sehematic representation of comeal reflection-centre of pupil method. A) Eve looks in the dircetion of the camera. B) Eye looks above the camera.

If the comera and light source are placed lar away from the subject (2-3m) and coaxially with the camera, slight head movements (several centimetre's) will not introduce a movement of the comeal reflex relative to the pupil centre (Bronson 1983). This simplifies the calculation 
of point of regard. If the head moves laterally, the comeal rellex also moves, thereby giving an indication of head movement. Using this method, it is essential that the light source is placed coaxially with the camera's axis and positioned directy beside the camera (Bronson 1983). If the light is not placed coaxially, the intensity of the retinal reflection will reduce dramatically, when the subject is fixating to the right or the left.

\subsection{System set-up.}

In order to place the camera, light source and visual stimulus coaxial, without the camera obstructing the subject's view of the visual stimulus, an infrared reflecting mirror is placed in front of the subject (Figure 6.2 ). The camera is placed effectively approximately 2.4 metres away from the object, with the light source placed right beside it. The small distance between the optical axis of the camera and the light source can be neglected; the effective angle between both is approximately $2^{\prime \prime}$. The subject is placed in front of a screen with a small rectangular opening. The size of this window is $17 \times 23.5 \mathrm{~cm}$. The $\mathbb{I R}$-mirror is placed at an angle of $45^{6}$ in the window (Figure 6.2). As a result, the only visual stimulus for the subject is the moving monitor and the subject's head is always in the field of view of the camera. In case of a small infant, the set-up allows the child to be carried either over the shoulder or to be seated on the lap of the parent. The parent can hold the head of the infant in both situations in front of the small window.

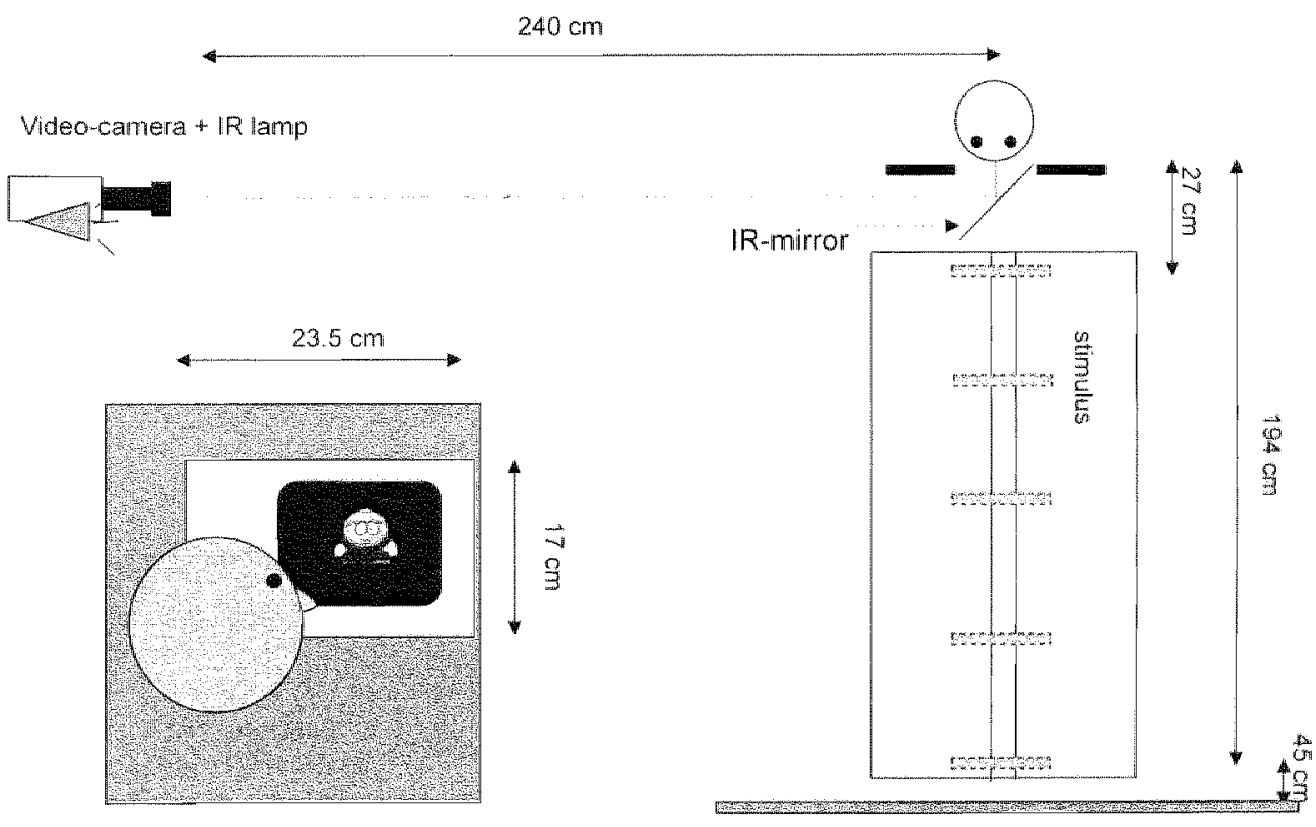

Figure 6.2. Arrangement of the eye tracking system.

The IR-light source is a 75 Whalogen lamp with an infrared band-pass filter. The source produces IR-light with a wavelength ranging from $800-950 \mathrm{~nm}$, with the optimum at $860 \mathrm{~nm}$. The irradiance levels at the cornea are well below IRPA guidelines on protection against nonionising radiation (1991). We have measured the exposure with a sensor at 2 metres from the 


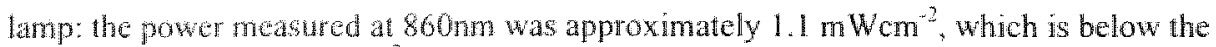
Exposure Limit of $0.7 \mathrm{Wcn}^{2}$ (exposure limit for direct ocular exposures of $700-1400 \mathrm{~nm}$ laser beam) from IRPA guidelines on protection against non-ionising radiation 1991.

The wide-band hot miror (Opticall Coating Laboratory Ine, Santa Rosa, California, USA) is optimised to reflect infrared light with an average of $90 \%$ from $750-1200 \mathrm{~nm}$ at an angle of incidence of $45^{\circ}$. The subject can look freely at the visual stimulus (transmittance of the mirror was $85 \%$ averaged for wavelengths of $450 \mathrm{~nm}$ to $675 \mathrm{~nm}$ ). The camera is a black and white CCD-camera (DMM 7003). A Computar ty zoom lens (H1021218MP) with a focal distance of $12-120 \mathrm{~mm}$ zooms in on both eyes of the subject. The field of view of the camera is approximately $11 \times 8 \mathrm{~cm}$. This field of view allows the subject to move several centimetres laterally. A S-VHS video recorder is used to save the recordings for possible off-line analyses. The black and white images are fed into a personal computer with a Matrox Meteor framegrabber. Here the images are digitised to 8-bit images with a resolution of $752 \times 582$ pixels at a sampling rate of $25 \mathrm{~Hz}$. The images are processed online (see next paragraph) to obtain the centre of pupil and comeal reflex of both eyes and are finally stored on disk.

The visual stimulus consists of a computer monitor placed on a rail. A silent motor, controlled by the computer, can move the monitor to the required positions. Presentlly, the fixation objects are small cartoon figures, whose appearance changed every few seconds to force the subjecis to keep attention. The size of the figures could be varied between $1 \mathrm{~cm}$ and $3 \mathrm{~cm}$ depending on the distance of the monitor to the subject. Depending on the subject"s age and interest, different ligures can be used. Animations can be used to draw the subject's attention (important in small infants and babies) and to observe smooth pursuit eye movements.

\subsection{Image processing and calibration.}

This section will tirst describe the algorithms used to find the centre of pupil and comeal rellex in the black and white images supplied by the ced-camera. Second, a calibration method will be described transforming the raw image data (pixel position of pupil and corneal reflex centre) to point of regard data in degrees visual angle.

\section{Cenfre of comeal reflex}

First the corneal reflections of both eyes are detected. The comeal reflex has the highest intensily, ideally the maximum intensity of the image (an image consist of 256 grey scales). A centre of mass calculation of a small area ( $10 \times 10$ pixels) surrounding the comeal reflex provides the centre of the reflex with sub-pixel accuracy:

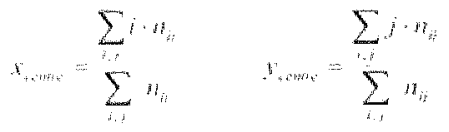

where

$x=x$-coordinate of centre of comeal reflex

$y=y$-coordinate of centre of comeal reflex

$i=$ column number of pixel

$j=$ row number of pixel

$n_{i j}=$ intensity of pixel 


\section{Centre of pupil}

The detection of the pupil centre is not as straightforward as the detection of the contueal reflex. Two problems had to be overcome: first, the intensity of the pupil varies considerately between subjects, and during a measurement; the intensity decreases when subjects gaze towards the left or right. Therefore setting a fixed threshold to detect the pupil during one measurement is impossible. A method was developed to adjust the level of threshold for each image individually, depending on the overall intensity of the pupil. Second in some subjects, overhanging eyelids covered parts of the pupil. A party covered pupil will introduce large errors in centre detection when using the centre of mass technique. Fitting an ellipse (Levine 1984) cannot solve this problem. When an overhanging eyclid covers the top part of the pupil, an ellipse will be fitted in the lower part of the pupil. As a result will the pupil centre be located too low. This leads to large errors in the detection of the vertical position of the pupil centre. Therefore we decided to fit a circle in the pupil.

Since the corneal reflex is usually located within the pupil, the location of the pupil is detected starting from the position of the comeal reflex. Two windows of $200 \times 200$ pixels are placed around both corneal reflexes, overlapping the complete pupils. Detection of the centre of both pupils is performed within these windows. First, a threshold is set to extract the pupil roughly from it's surrounding. The threshold was determined by calculating the average intensity of two small windows (each $10 \mathrm{x} \| 0$ pixels) around the comeal reflex. The threshold was calculated by averaging the intensity of the two windows minus the standard deviation of the intensity of the complete pupil. Using this method, the threshold level is placed relatively low when the variability of the pupil's intensity is high. Second, the threshold procedure sometimes leaves several surrounding structures, such as the tip of the nose. By using a recursive region-growing algorithm (e.g. Gonzales 1992) only the pupil is subtracted from the image. Finally, 15 horizontal pairs of edge points of the thresholded pupil are determined. The horizontal position of the centre of the pupil is determined by calculating the middle of the left edge and right edge. Fitting circles in all combination of edge pairs determine the vertical position of pupil centre, also with sub-pixel accuracy.

\section{Calibration procedure.}

A bi-quadratic approximation function is used to relate the measured eye parameters (i.e. positions of the centre of pupil and coneal reflex in pixel coordinates) lo lixation points. The location of the eyes, relative to the camera and the screen, can be obtained from the position of the comeal reflex. The orientation of each eye is calculated from the differential tocation of the corneal reflex relative to the pupil centre. The eye orientation in visual angle is mapped on the visual target, i,e the monitor. Define a Cartesian coordinate system ( $X$, Y) on the camera image. Let the coordinates of the pupil centre be $\left(X_{p}, Y_{p}\right)$ and of the comeal reflex $\left(X_{t, r} Y_{c}\right)$. Define relative coordinates $X_{n}=\left(X_{p}-X_{0}\right)$ and $Y_{r}=\left(Y_{p}-Y_{c}\right)$. These are related to the angular orientation of the eyeball, being zero when the eye is amed at the CCD-camera. Define a second coordinate system $(X, Y)$ on the visual target (monitor), the point of am on the monitor is $\left(X, Y_{i}\right)$.

$$
\begin{aligned}
& X_{r}=\left(A+B X_{r}+C Y_{r}+D X_{r} Y_{r}+E X_{r}^{2}+F Y_{r}^{2}\right)+\left(G X_{r}+M Y_{r}+\Lambda\right) \\
& Y_{r}=\left(J+K X_{r}+L Y_{s}+M X_{r} Y_{s}+N X_{r}^{2}+O Y_{r}^{2}\right)+\left(P X_{r}+Q Y_{r}+R\right)
\end{aligned}
$$


This method is similar to the method described by Levine (1984), with the addition of two extraterms (I and $R$ ) in the final equations. The calculated aiming point on the monitor is made to depend on the direction of gaze (first six terms in the equation) and on the location of the eye in space relative to the display screen (last three terms). The last three tems can be obtained by a one-time measurement, since they only depend on the position of the camera relative to the subject's head and field of view of the camera. To do this, a card with a rectangular grid of spots is placed in the position of the subject's head. The camera takes an image of this grid, and the six constants $(G, H, I, P, Q$ and $R)$ are calculated from the known grid spacing. The remaining constants ( $A-F$ and J-O) are user-dependent and should be performed for each subject individually. This is done by showing the subject a sequence of targets with known spacing in the horizontal and vertical direction. A number of positions of pupit and corneal reflex are stored for each target and a least-square fitting procedure calculates the remaining constants.

\subsection{Aceuraicy}

\section{Method}

In order to assess the accuracy of the system, measurements were performed simultaneously with seleral coils, Two dimensional (horizontal and vertical) measurenents were performed with the coils system at a sampling rate of $200 \mathrm{~Hz}$. The subject (male aged 24 , with normal vision) was placed in the centre of the scleral search coil system with the head stabilized using a bite-board. Prior to each experiment, gain and offset of the $2 \mathrm{D}$-coils were calibrated using a gimbals calibration device placed near the centre of the coil system. Eye movements were measured with botl systems while the subject fixated a number of targets presented on the monitor, at various distances (see Table 6.1). The target on the montor was a small cartoon figure placed in a rectangular grid of 9 positions on the monitor. The horizontal and vertical displacement between positions was always a fixed angle. Table 6.1 shows the different angles between target positions for the various distances of the monitor. The expected vergence angle was calculated from the subject's interpupilary distance of $6.5 \mathrm{~cm}$.

Table 6.1. Fixation distance, visual angle between stimuli (grid posintons) and expected vergence angle and measwed vergence angle in the stratgh-ahead gaze position. Calbration was performed using the measuremen makd with*

\begin{tabular}{|c|c|c|c|c|}
\hline $\begin{array}{l}\text { Distanger } \\
\text { [am] }\end{array}$ & 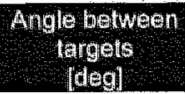 & $\begin{array}{l}\text { Experted yergenos } \\
\text { gngle } \\
\text { [deg] }\end{array}$ & $\begin{array}{l}\text { Measured vergence } \\
\text { ydeo } \\
\text { [dog] }\end{array}$ & $\begin{array}{l}\text { Measured vergence Coils } \\
\text { [deg] }\end{array}$ \\
\hline 64 & 8 & 5.8 & $6.1+0.3$ & $5.66 \pm 0.07$ \\
\hline 80 & 7 & 4.7 & $4.8 \pm 0.4$ & $4.59 \pm 0.08$ \\
\hline $100^{*}$ & 5 & 3.7 & $3.9 \pm 0.3$ & $3.77 \pm 0.07$ \\
\hline 100 & 5 & 3.7 & $4.3 \pm 0.2$ & $3.65+0.07$ \\
\hline 100 & 5 & 3.7 & $39 \pm 0.3$ & $3.81 \pm 0.06$ \\
\hline 130 & 3.5 & 29 & $26 \pm 0.5$ & $25.4+0.07$ \\
\hline 130 & 4 & 29 & $3.1 \pm 0.3$ & $2.95 \pm 0.06$ \\
\hline 231 & 2 & 1.6 & $1.4 \pm 0.3$ & $1.19 \pm 0.07$ \\
\hline
\end{tabular}


Resulis

Calibration of the video-system was performed with the monitor at $100 \mathrm{~cm}$ from the subject (marked with * in table 6.1 ); the angle between targets was $5^{\circ}$. All other results were corrected using equation 1 and 2 with coefficients obtained from the calibration. Figures 6.3 a and $b$ show the eye movements of one eye in one trial spatially. In figure $6.3 \mathrm{~b}$ each group (position of fixation object) of data points was averaged and standard deviation calculated.

The "fixation clouds" of the video-system are larger than those of the scleral seareh coils. Average standard deviation in the horizontal direction of the video system was $0.3^{\circ}$ compared $100.1^{\circ}$ for the scleral colls (average of 9 fixation points from calibration procedure). In vertical direction the average standard deviation for the video system is $0.6^{\circ}$ and $0.1^{\circ}$ for the coils. These standard deviations were similar in all other fixation conditions. When the target was close to the subject, measurements became more difficult, since the bright pupil reflection was less pronounced.

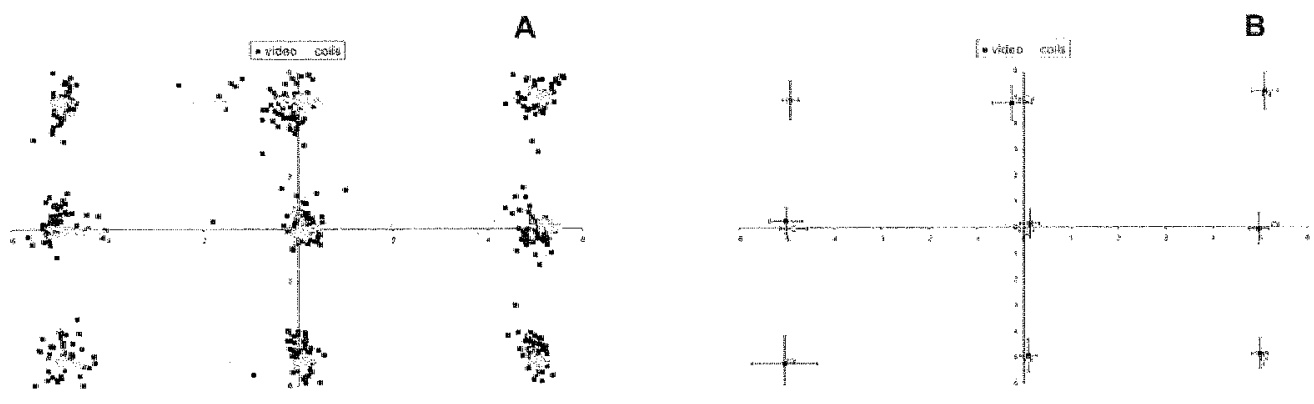

Figure 6.3. A) Fertical versus horizonal tye movements of the right oye with the largets at $100 \mathrm{~cm}$ from the subject. Horizontal and wertical angle berween target positions is $5^{\prime}$. B) A werage with shandard deviaton of each target position of both systems. Grey dots are scleral search coil resuls. black dots those of the video sysicm.

Figures 6.4A and B show both horizontal and vertical coil and video traces of the right eye as a function of time. Coill data was resampled in order to show the temporal correlation between both data. Figures $6.4 \mathrm{C}$ and $\mathrm{D}$ show the correlation between both systems. The linear correlation coefficient $\left(\mathrm{R}^{2}\right)$ is 0.98 horizontally and 0.95 vertically, indicating that horizontal eye movements are measured more accurate than vertical eye movements using the video system. 

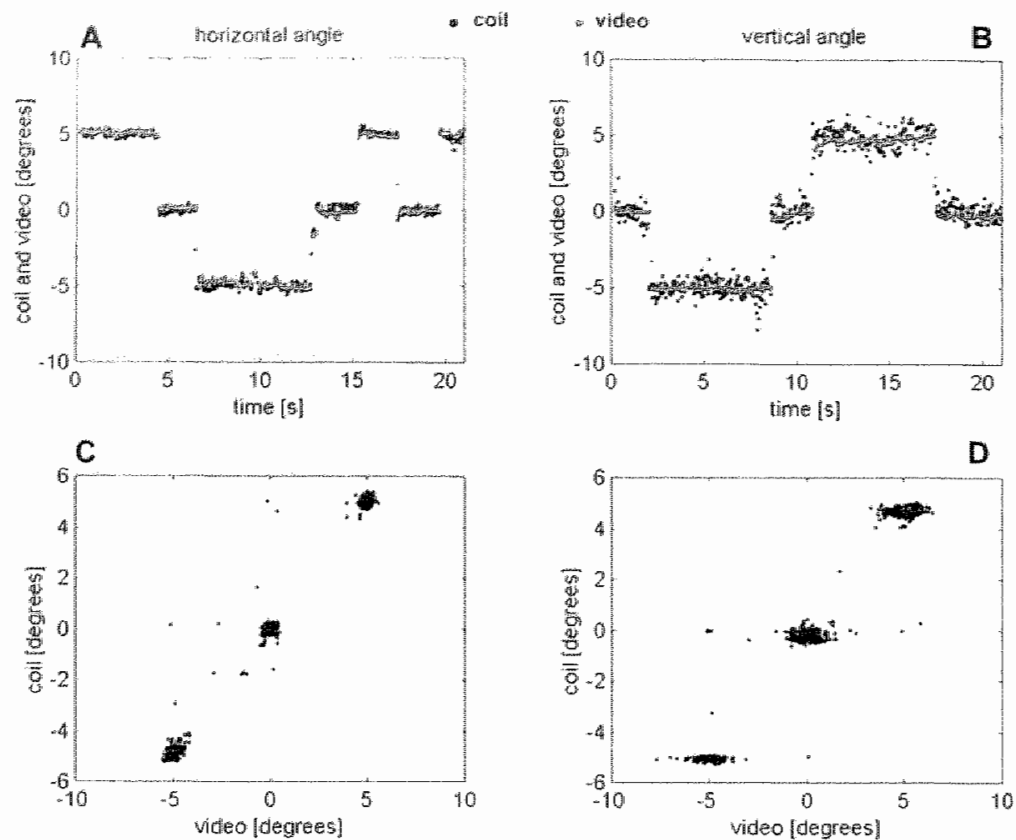

Figures 6.4. A) Horizontal and B) vertical coil and video traces of the righteye as a function of time. Grey dors are scleral search coil results, black dots those of the video system. C) Monizontal and D) werfical coil wersus video results, showing the correlation between both systems.

To compare eye movements of both eyes, the vergence angle was calculated for straightahead gaze in all five monitor positions. The results are shown in Table 6.1 and Figure 6.5 . They show the theoretical and measured wergence angle of the coils and the video system with standard deviations. In figure 6.5 , only posifive standard deviations are shown for the video system and negative deviations for the coil system to avoid overlapping error bars. 


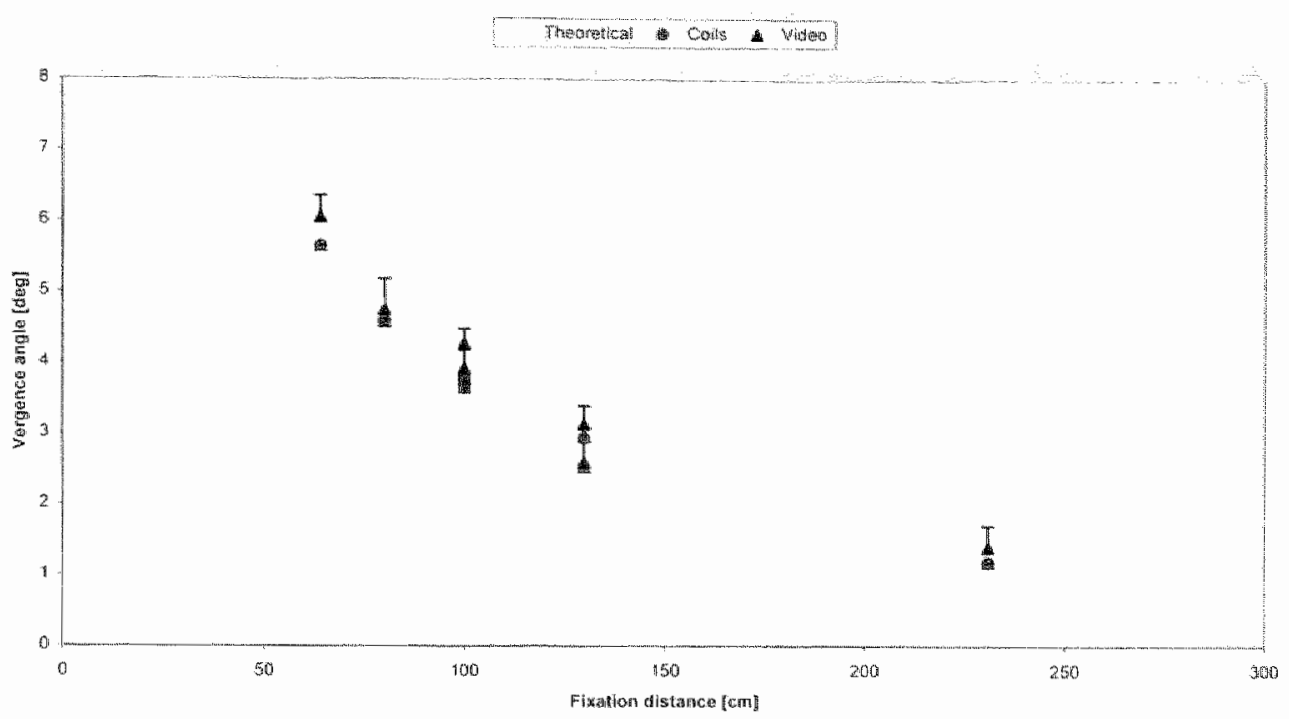

Figue 6.5. Theoretical (-), search coll (ond andeo (-) wergence angle as a function of fixation distance.

\section{Conchuding remarks on accuracy.}

The increased spread in horizontal and vertical eye movements compared to the coils has several causes. Levine (1984) suggests that the error is mainly due to the quantification effect produced by the discrete video raster. This error is probably the man reason for the observed difference between horizontal search coil and video signals. Increasing the resolution of the camera or zooming in on the eyes will increase the accuracy of the system. Another system error is induced by the fact that a camera-image is build from two interlaced frames (two raster of alternate frames which are displaced vertically by half their spacing). This means that when we have a full image (25 times per second), it is build from 2 frames with a stigh temporal displacement of 20 miliseconds. A fast eye movement can cause a shift between both frames. A solution for this problem is, by working with each frame individually. This way the sampling frequency of the system becomes $50 \mathrm{~Hz}$. However, the resolution of the image vertically is halved: this further reduces the accuracy of the vertical cye movements' registration. When only horizontal eye movements are of interest is this the perfect solution.

In the data, a difference in accuracy between horizontal and vertical eye movements meastred with the video system was observed. This difference is a result of the difference in calculation of horizontal and vertical position of the pupil centre. The horizontal position of the pupil centre is detemined by taking the middle of 15 horizontal pairs of edge points. It is an accurate method of determining the centre of an object, not necessarily a circle. Howeve", the vertical position is determined by fitting circles in the edge pairs. These circles determine the vertical position of the centre. Two factors can induce small errors in this method. First, the pupil is not exactly a circle and the shape of the pupil is distorted slightly by the connea, depending on the fixation direction. Therefore the calculated centre of pupil will not coincide with the real pupil centre depending on gaze direction. Second, during fast eyc mowements a slight difference between image-frames can occur. In the calculation of vertical position, two 
lines are wsed, where one line can be of one frame and the other line can be of the second fane. When the difference between two frames is large, erroneous circles are fitted. The last factor stso inlluances the detection of the horizontal position of the pupil centre, al hough this crror is smaller. Additionally, horizontal position is determined for each frame-line individually and all results are averaged. This average procedure reduces the noise by a factor of $\sqrt{2}$ (wo interlaced images are used for one time frame). This results in a seemingly higher accuracy of horizontal eye position by a factor of 1.4 compared to vertical positioning. However this is insufficient to account for the total difference between the two (factor \pm 2 ). Note however, that the observed error in vertical direction is at sub-pixel level. If we calculate a standard deviation of $0.6^{6}$ back to pixels, it is approximately 0.4 pixels.

\section{7 Conclusion}

With this new binocular 2D-video system, we have a tool in hand to measure binocular eye movements in both adults and in babies. The set-up for an experiment is quick, and easy to perform. The accuracy of the system is for horizontal eye movements higher (standard deviation $: 0.3^{6}$ ) than for vertical eye movements (standard deviation $\pm 0.6^{\circ}$ ).

\subsection{Literature}

Blakemore C. (1976) The conditions required for the maintenance of binocularity in the kitten's visual cortex. J.Physiol. 261, p. 423-444.

Bronson G. (1983) Potential sources of error when applying a comeal reflex eyemonitoring technique to infant subjects. Behav.Res.Meth.\&.Instr. 15, p. 22-28.

Gonzales, Woods. (1992) Digital image processing Addison-Wesley publishing company.

Hainline L., Riddell R., Grose-Fifer J. and Abramov I.(1992) Development of accombodation and convergence in infancy. Behav. Brain Res. 49, p. 33-50.

Haith M.M. (1969) Infrared televiston recorting and measurement of ocular behaviour in the human inlant. Am. Psych. 24, p. $279-282$.

von Holsten $\mathrm{C}$. and Rosander $\mathrm{K}$. (1997) Development of smooth pursuit tracking in young infants. Vision Res. 37, p. 1799-1810.

Jacols M., Harris C.M., Shawcat F. and Taylor D. (1997) Smooth pursuit development in infunts. Aus.\&N.Z. J. Ophthalm. 25, p. 199-206.

LeVay S., Wiesel T.N. and Hubel D.H. (1980) The development of ocular dominance columns in normal and visually deprived monkeys. J. Comp. Neurol. 191, p. 1-51.

Levine 1.L. (1984) Performance of an eyetracker for office use. Comput. Biol. Med. 14, p. 7789.

Merehand J. (1969) Laboratory oculometer. NASA Report CR-1422. 
Roucoux A., Culee C. and Roucoux M. (1983) Development of fixation and pursuit aye movements in human infants. Behav. Brain Res. 10, p. $133-139$.

Young L. and Sheena D. (1975) Methodsddesigns: Survey of eye movement recording methods. Behav.Res.Meth.\&Instr. 7, p. $397-429$ 
Chapter 6 


\section{Chapter 7}

Summary. 
Chapter? 


\subsection{Summary.}

If we look with both eyes at an object, our brain can fuse the images from both eyes into one three dimensional object. This process, called stereopsis, only functions when both eyes are pointed accurate towards the fixation object and can actually see the object with both eyes. A subject will have no or limited stereopsis when one of these demands is not obeyed, as is the case in subjects with strabismus (cross-eyed vision) or amblyopia (lazy eye). In nomal healthy subjects, all three-dimensional eye movements ean be deseribed using Listing "s law. This law can predict all eye orientations in three dimensions (horizontal, vertical and torsional) accurately. Although in nomal subjects all eye movements have been described. accurately, the purpose and origin of this law is still not completely known. Several aspects are still unclear of which some are discussed in this thesis. Why do our eyes move in such a specific way, how does visual feedback aid binocular control of eye movements and how are our eye movements controlled neuronally? Another aspect that was investigated is the question whether patients with strabismus and amblyopia obey the same laws as nomal healthy subjects do.

Finally a binocular eye movement system is described, that can measure horizontal and vertical eye movements using a ccd-camera. With this system, the development of binocular eye movements in babies can be investigated.

Chapter 1, presents a basic overview in the field of binocular eye movements. In this chapter the various types of eye movements, basic anatomy of the eye muscles, Donders" and Listing's law and the definition of binocularity is described.

In chapter 2 the influence of a sudden change in visual input on the vestibulo-ocular reflex was assessed. During head shaking, the visual input of both eyes was changed rapidly by means of a displacement prism. As a consequence, the subject has to make a horizontal vergence eye movement (i.e. a disconjugate eye movement) in order to prevent double vision. It was shown that during fast head shaking, adlaptation takes place in each eye individually, however, the total change in vergence was slightly lower $(<25 \%)$ than was anticipated. In literature, it is often assumed that the velocity gain (ratio of eye movement over head movement) of the vestibulo ocular reflex is directly related to the vergence angle. The vergence angle of the eyes is related to the distance of a fixation object from the head: the vergence angle is zero when the object is at a great distance, and increases when the object approaches. If an object approaches a moving head, the eyes have to move faster in order to stabilize the image on the retina. In this experiment, the vergence angle is changed by the prism, but the distance of the fixation object from the head is constant. In this situation, the eyes should not move faster or slower in the new situation: the velocity gain should remain constant. However, the velocity gain of the vestibulo ocular reflex decreased slightly with an increase of vergence angle. These results show that the velocily gain of the vestibulo ocular reflex is not under direct control of vergence but probably is controlled for each eye individualy. It was suggested that besides retinal slip also retinal image position in each eye individually has a major influence on eye movements even at high head rotation frequencies.

In chapter 3 , stability of binocular eye movements during smooth pursuit was investigated in normal subjects and in subjects with diminished stereopsis. In this chapter, the validity of Donders' law is investigated during smooth pursuit. Donders" law states, that independent of 
the puth the eye takes, the threedimensional orientation of the eye is always the same in each fixation direction. The results show that, in normal subjects, Donders' law was obeyed during smouth pursut tye movements, although there were some small deviations: all subjects showed a temporal dissociation between horizontal and torsional eye movements. These dissociations lead to hysteresis, which is a direct violation of Donders law. The observed phase shift between horizontal and torsional eye movements may have been caused by biomechanical factors at the plant: a combination of elasticity and viscosity of the oculomotor plant affect the velocity of eye movements. Viewing conditions did not influence the stability of vergence eye movements in nomal subjects. This may indicate that real-time visual feedback from both eyes is not essential for binocular coupling, during smooth pursuit, in normal subjects.

In order to investigate the binocular coupling of eye movements, vergence stability was investigated. In subjects with micro-strabismus without amblyopia, we found no significant difference in size of horizontal and vertical vergence stability compared to our normal subjects. Vertical vergence stability was highest, followed by horizontal vergence stability. Torsional vergence was less siable compared to controls. In our subjects with amblyopia we observed both horizontal and torsional vergence instability compared to normal subjects. From these results it is most likely to conclude that horizontal vergence instability is predominantly caused by amblyopia.

In patients with strabismus and/or amblyopia, horizontal vergence stability depended on which eye was fixating the target. Although the amount of subjects participating in the experiment and the observed variability does not allow us to make wide generalisations, we suggest the following: it is possible that vergence stability is controlled visually in subjects with strabismus. When these subjects look monocularly with their squinting eye, information of the periphery of the retina is mainly used where acuity is lower. In contrast to normal subjects, who apparently do not need visual feedback for binocular coupling of eye movements, real time visual feedback is essential in patients with strabismus during smooth pursuit.

In chapter 4 we investigated whether Listing"s law applies in patients with diminished or no stereopsis. Listing's law describes specinteally the torsional orientation of an eye in each lixation direction. II states that all rotation vectors describing eye movements are positioned in a flat plane: the so-called displacement plane. In this experiment the shape and orientation of the displacement planes were measured in both patients and controls. Three-dimensional cye movements of normal subjects and patients with strabismus and/or amblyopia were registered during monocular and binocular fixation conditions.

The control group and patient with amblyopia due to anisometropia showed nomal Listing behaviour. Patients with strabismus and amblyopia obeyed Listing's law less accurate: the planes of both eyes were thicker compared to the normal subjects and the relative orientation of the planes, i.e. the angle between both planes, varied with fixation conditions, indicating that Listing's law is not aceurately obeyed in these patients. These results show, that nomal Listing behaviour can be present in subjects with diminished stereopsis. It also shows that notmal stereopsis does not necessarily mean normal Listing behaviour. Because no clear relation was found between stereopsis and the shape and orientation of displacement planes, it would appear that Listing"s law is mainly a result of motor stralegy. 
In chapter 5 three-dimensional eye movements of five adult patients with strabismus were measured before and after strabismus surgery "thereby investigating the infuence of a radical change in mechanical properties of the eye plant on the three dimensional binocular eye movements. From the datat, the shape and orientation of the displacement planes was determined. We inwestigated whether Listing"s law is a consequence of two-dimensional control, where eye torsion is determined by biomechanical properties of the orbita, or whether it is a reflection of full three-dimensional neuronal control. If Listing"s law were the result of two-dimensional neural control, the operation would have a large effect on the eye movements. After the operation, four out of tive patients obeyed Listing's law more accurately. In one patient, the changes were hardly detectable. In all patients who were operated in one eye, the monocular orbital change caused binocular inprovements of torsional control. The relative orientation of both displacement planes also changed, however no clear relationship was found between type of operation and direction of rotation. These results show, that Listing's law is not just a result of biomechanical properties of the deye plant, but must have a neural basis. Therefore, Listing"s law is a reflection of full threedimensional neuronal control.

In chapter 6, a system was described to measure two-dimensional binocular eye movements with one video cantera placed at \pm 2.5 meters from the subject. The system uses the contheal reflex-bright pupil technique to register horizontal and vertical eye movements 25 iimes per second. Due to the non-intrusive and easy set-up eye movements of both adults and small infants (babies) can be measured. The accuracy of the sysiem was measured by comparing its results with simultaneous measurements using scleral search coils in a healthy subject. During steady fixation both systems showed a slight spread in data-points: the video system showed a standard deviation of $t 0.3^{0}$ horizontally and $\pm 0.6^{*}$ vertically compared to $\pm 0.1^{6}$ in both directions wher measured with scleral search coils. The correlation coefficien between both systems is 0.98 horizontally and 0.95 vertically, indicating that horizontal eye movements are measured more accurate than vertical eye movements. With this new video system, we have a tool to measure two-dimensional binocular eye movements in both adults and babies.

\subsection{In conclusion.}

The basic questions in this thesis are how we control our eyes thee-dimensionally and why in the specific way as alleady was deseribed by Ructe and Listing in 1853 . This thesis, and earlier investigations, showed that it is not casy to describe the eye movements of patients with strabismus and/or amblyopia in a simple model. As a result, this thesis does not present new rules that apply to these patients, but instead shows the differences with cye movements of normal subjects. From these results we could make the following conclusions.

In chapter 5 we determined that the brain controls all eye movements in three dimensions (horizontal, vertical and torsional), instead of the also mentioned wo dimensional model. The brain then weighs two factors: the optimization of ocultar motor control and assistance of binocular vision. In chapter 4 we concluded that the brain appears to put more weight on the optimization of ocular motor control than on the assistance of binocular wision. The results in chapter 2 suggested that in hoalthy subjects, visual feedback can influence binocular eye movements, even during fast head movements. In chapter 3 we saw, that patients with diminished stereopsis used visual feedback for small adjustments in eye movements. These patients, in contrast to nomal subjects, appear to use information from the periphery of the retina, 10 adjust their eye movements. 
Strabismus and amblyopia can stant to manifest themselves in the first months after birth and can be caused by optical, neurological or musculat factors. The balance of these mechanisms is delicate. Both motortc and sensoric development of binocularity takes place at the same time in these frrst months. By measuring eye movements of small infants with the system described in chapter 6 , normal development of binocular eye movements can be recorded. Perhaps, this information can be used in the future to intervene sooner and more effectively when the development of a small child is disturbed. 


\section{Chapter 8}

Samenvatting. 
Chapler 8 
Als met beide ogen gekeken wordt naar een voorwerp, kunnen onze hersenen de informatie wan beide ogen combineren en hierwan een dieptebeeld maken (stereopsis). Dit kan echter alleen als beide ogen daadwerkeljik nauwkeurig op het voorwerp gericht zin en het voorwerp kunnen waamemen. Indien aan een van deze voorwaarden niet wordt voldaan, zal stereopsis in mindere mate of helemaal niet aanwezig zijn. Dit geldt bijvoorbeeld voor patienten die scheelzien (strabismus) of een luil oog hebben (amblyopia). Bij gezonde proefpersonen kumen de binoculaire oogbewegingen beschreven worden met behulp van de wet van Listing. Deze wet voorspelt de oogoriëntaties in drie dimensies (horizontaal, vertical en torsioneel) nauwkeurig. Hoewel de oogbewegingen van gezonde proefpersonen nauwkeurig beschreven zijn, is de oorsprong en achtergrond van de wet van Listing nog steeds niet volledig begrepen. Een aantal aspecten zijn vooralsnog onbekend. In dit proefschrift worden aan arantal van deze aspecten onderzocht. Waarom bewegen onze ogen op deze specifieke manier, in hoeverre draagt visuele terugkoppeling bij tot de binoculaire controle van oogbewegingen en hoe worden de oogbewegingen neuronaal gecontroleerd? Een andor aspect dat wordt onderzocht is de vraag of patiënten met strabismus of amblyopie dezelfde wetten volgen als gezonde proefpersonen. Tenslotte wordt een systeen beschreven warme binoculair horizontalle en verticale oogbewegingen gemeten kumnen worden met een videosysteem. Dit systeem kan worden toegepast bij onderzoek naar de ontwikkeling van binoculaire oogbewegingen bij pasgeborenen.

In hoofdstuk 1 wordt een algemene inleiding gegeven op het gebied van oogbewegingen. In dit hoofdstuk komt onder andere aan bod de verschillende types oogbewegingen, anatomie van oogspieren, de wetten wan Donders en Listing en de definitie van binoculariteit.

In hoofdstuk 2 wordt onderzocht wat de invloed is van een snelle verandering van visuele informatie op de binoculaire controle van oogbewegingen. Terwijl de proefpersoon snel met zijn hoofd schudt wordt door middel van een prisma de visuele informatie plotseling veranderd. Dit prisma heeft tot gevolg, dat de proefpersoon een horizontale vergentiebeweging (een ged isconjugeerde oogbeweging) dient te maken om te voorkomen dat hij dubbel ziet. Het experiment toont aan dat beide ogen zich individueel aanpassen aan de. neuwe situatie. De aanpassing was echer kleiner dan verwacht: de verandering van vergentichock was $25 \%$ kleiner dan verwacht.

In de literatur wordt er regelmang vanuit gegan, dat de velocily gain (ratio van de snelheid van oogbeweging en hoofdbeweging) van de vestibulo-oculare rellex direct gekoppeld is an de vergentiehoek. De vergentiehoek van de ogen is namelijk direct gerelateerd aan de afstand tussen het hoofd en het fixatievoorwerp: de vergentiehock is nul bij een 'blik op oncindign' neemt toe als het voorwerp het hoold nadert. Als een voorwerp een bewegend hoofd nadert, dienen de ogen sneller te bewegen on het beeld te stabiliseren op de retina. In dit experiment, word de vergentiehoek veranderd door middel van een prisma, zonder de afstand van het voorwerp te veranderen. In deze situatie dienen de ogen dus niel sneller te bewegen. oftewel de velocity gain van de vestibulo-oculaire reflex dient constant te blijven. Het bleek echter, dat de velocity gain licht verminderde bij een convergente oogbeweging. Dit resultaal toont aan dat de velocity gain niet direct gecontroleerd word door een vergentiemechanisme, mar waarschijnlijk door visuele informatie van elk oog individued. Hierdoor zou het mogelijk kunnen zijn, dat naast retinale slip ook retinale beeld positionering in elk oog invloed necli op de oogbewegingen, zelfs tijdens snelle hoofdbewegingen. 
In hoofdstuk 3 word de stabihitit van binoculare oogbeweging tijdens smooth pursuit (een gladde volgbeweging) bepuald bij gezonde proefpersonen en bij patienten met microstrabismus (scheclzienshoek keiner dan $5^{\text {it }}$ ) enof amblyopie. In dit hoofdstuk wordt de validiteit van de wet van Donders onderzochi tijdens smooth pursuit. De wet van Donders steli, dat de oogorientatie in een bepaalde kijkrichting altijd hetzelfde is, onathankelijk van de weg die het oog heeft afgelegd om in die positie te komen. De resultaten tonen aan dat de groep gezonde proefpersonen de wet wan Donders redelijk nauwkeurig gehoorzaamt, hoewel er keine afwijkingen zijn: er wordt en faseverschil geconstateerd tussen horizontale en torsioncle oogbewegingen. Dit faseverschil leidt tot hysterese, wat een schending is van de wet van Donders. Deze kleine afwijkingen worden waarschijnlijk veroorzaakt door een. combinatie van viskeuze en elastische eigenschappen van het oog en de oogspieren aangezien deze een directe inwloed hebben op de snetheid van oogrotaties. Monoculaire kijkcondities bliken geen invloed te hebben op de vergentiestabiliteit van de gezonde proefpersonen. Hieruit kan worden afgeleid dat in deze groep, real-time visuele terugkoppeling van beide ogen niet noodzakelijk is voor de binoculaire koppeling van oogbewegingen.

Om de mate van koppeling van oogbewegingen van de patienten te vergelijken met die van gezonde proelpersonen werd vervolgens de vergentiestabiliteit bepaald. De verticalle vergentiestabiliteit was hoger dan de horizontale vergentiestabiliteit in de groep patiênten met micro-strabismus zonder amblyopie, echter beide waren niet significant lager dan de controle groep. De torsionele vergentiestabiliteit (cyclovergentie) was wel lager dan in de controle groep. Zowel de horizontale als torsionele vergentiestabiliteit was bij de patiënten met amblyopie lager vergeleken met de controle groep. Uit deze resultaten kan worden afgeleid dat horizontale vergentieinstabiliteit voomamelijk wordt veroorzaakt door de amblyopie. Tenslotte bleck in alle patienten de mate van horizontale vergentiestabiliteit af te hangen van de kijkcondities. Hoewel het aantal proefpersonen en de mate van variabiliteit tussen proefpersonen het ons niet toestaat om algehele conclusies te trekken, kan het volgende dit resultaat verklaren: wellicht wordt in patiënten met strabismus, in tegenstelling to gezonde proefpersonen, de vergentiestabiliteit visueel gecontroleerd. Bij de gezonde proefpersonen bleek het aflekken van één oog geen invloed te hebben op de vergentiestabiliteit, dit in tegenstelling lot de patiëntengroep. Wellicht hebben deze patiënten visuele terugkoppeling nodig voor de binoculaire controle. Aangezien de visuele informatie van het aangedane oog van deze patienten minder scherp is, zou dit direct invloed kunnen hebben op de vergentiestabiliteit.

In hoofdstuk 4 wordt onderzocht of patienten met strabismus en/of amblyopie de wet van Listing gehooramen. Een afleiding van deze wet stelt, dat de rotatievectoren wan de bewegingen van een oog in én plat vlak dienen te liggen: het zogenaamde displacement plane. In dit experiment wordt de vorm en oriëntatie van de displacement planes bepaald in beide ogen van cen groep patiënten en vergeleken met die van een controle groep. Daartoe werden de driedimensionale oogbewegingen gemeten tijdens monoculaire en binoculaire lixatio condities.

Bij de controle groep en een patiënt met amblyopie door anisometropie werden normale displacement planes aangetroffen. De patientem met strabismus en amblyopie gehoorzaamden de wet van Listing in mindere mate dan de mensen in de controlegroep. Dit bleek doordat zowel de displacement planes van de patiënten dikker waren en de relatieve orièntatie, oftewel de hoek thissen de displacement planes van bejde ogen, aanzienlijk varieerde tussen fixatic condities. Dit laatste gebeurde niet in de controle groep. Uit deze resultaten kan 
worden geconcludeerd dal nomaal Listing gedrag kan voorkomen bij patiẻnten met verminderde stereopsis. Echter het ongekeerde word ook aangetoond: een parient net normale stereopsis vertoonde abnomal Listing gedrag. Aangezien er geen directe relatic ontdekt kon worden tussen de mate van stereopsis en de vorm van de displacement planes lijkt het erop dat de wet van Listing grotendeels het gevolg is van een motor strategie.

In hoofdstuk 5 werden de driedimensionale oogbewegingen van vijf volwassen strabismus patienten gemeten voor en na een correctie operatie. Uit de data werd verwolgens de worm en oriëntatie van de displacement planes bepaald. Aan de hand ran deze waardes werd onderzocht of onze oogbewegingen het gevolg zijn van een tweedimensionale of driedimensionale neuronale aansturing. In het driedimensionale paradigma worden horizontale, verticale en torsionele oogbewegingen neuronal gesturd. In het andere paradigma wordt alleen de horizontale en verticale beweging neuronaal gestuurd, en wordt oogtorsie (de derde dimensie) volledig bepaald door biomechanische eigenschappen wan het oog en de oogspieren. De operatie heeft een radicale invloed op de biomechanische eigenschappen van de oogspieren en zou met name grote invloed moeten hebben op de oogbewegingen als het tweedimensionale paradigma van toepassing is. Na de operatie bleken vier van de wijf patiënten de wet van Listing beter te gehoorzamen dan ervoor. Bij én patiënt. kon amper een verschil worden aangetoond. Tevens bleek dat bij alle patiënten die aan é̉n oog waren geopereerd, de operatie inwloed had op de oogbewegingen van beide ogen: met name de binoculaire controle van torsionele oogbewegingen verbeterde, oftewel nam de cyclovergentiestabiliteit toe. Er kon geen eenduidige rellatie gevonden worden ussen type operatie en oriëntatie verandering van de vlakken. Deze pesultaten tonen aan dat de wet van Listing niet slechts het gevolg is wan biomechanische eigenschappen van het oog en de spieren, maar dat het een neuronale basis heeft. Oftewel, onze oogbewegingen worden driedimensionaal neuronaal aangestuurd.

In hoofdstuk 6 wordt een systeen beschreven warmee binochlair, iweedimensionalle oogbewegingen gemeten kumnen worden met behulp van een videocamera geplaatst op $\pm 2.5 \mathrm{~m}$ afstand van de proefpersoon. Het systeem makt gebruk van de comea reflectic die ontstat doordat naast de camera een infrarood lamp geplaatst is. Het systeen meet de positic van de cornea reflecties ten opzicht van de pupil centra (welke helder zijn opgehcht) en bepaalt hieruit automatisch de horizontale en verticale positie van beide ogen $25 \mathrm{keer}$ per seconde. Het systeem is uitermate geschikt om de binoculare oogbewegingen van baby is cn kleine kinderen te meten, aangezien het systeem de proelpersoon niet belast en snel kan wonden opgezet. De nawweurgheid van het systeem werd bepald door metingen te verrichton bij een proefpersoon, gelijklijdig met de "gouden standard"; het scteral coills systeem. Tijdens fixatie toonden beide systemen een kleine spreiding in datapunten: het wideo system had een horizontale spreiding (weergegeven in standaard deviaties) van $\pm 0.3^{\prime \prime} \mathrm{en}$ een verticalc: spreiding van $\pm 0.6^{6}$, terwijl het coilsysteem een spreiding loonde van $\pm 0.1^{67}$ in beide richtingen. De correlatie coefficient tussen de data van boide systemen was 0.98 horizontaal en 0.95 verticaal. Deze resulater tonen an dat het videosysteen horizontal systematisch nauwkeuriger meet dan verticad. 


\subsection{Concluderend}

Aan de basis van dit proefschrift liggen de vragen hoe onze ogen worden aangestuurd en waarom op de specifeke manier zoals Ruete en Listing reeds in 1853 hebben beschreven. Bij patienten met strabismus en/of amblyopie blijkt het niet zo eenvoudig te zijn om hun oogbewegingen eenduidig te beschrijuen en te modelleren. In dit proefschrift worden derhalve niet de regels beschreven die de ogen van deze mensen volgen, maar worden de afwijkingen ten opzichte van gezonde proefpersonen beschreven. Aan de hand van deze resultaten konden we een aantal zaken waststellen.

In hoofdstuk 5 stelden we vast dat de hersenen de ogen in drie dimensies aanstuurt, dit in tegenstelling tot het eerder genoemde tweedimensionalle model. Hierbij wordt een weging gemakkt tussen de optimalisatie van de oogbewegingen en de ondersteuning van de binoculaire functies, waarbij de optimalisate van oogbewegingen zwaarder gewogen wordt dan de ondersteuning van de binoculaire functie (hoofdstuk 4).

Uit hoofdstuk 2 bleek dat bij gezonde proefpersonen visuele terugkoppeling van elk oog afzonderlijk, zelfs bij snelle hoofdbewegingen. invloed kan uitoefenen op de oogbewegingen. In hoofdstuk 3 werd geopperd, dat patiënten met verminderde stereopsis visuele terugkoppeling gebruiken voor luleine correcties van oogbewegingen. Deze patienten, in tegenstelling tot gezonde proefpersonen, lijken op deze manier aan de hand van grove, perifere informatie van de retina, de oogbewegingen te corrigeren.

Oogaandoeningen zoals strabismus en amblyopie kunnen zich reeds manifesteren in de cerste maanden na de geboorte wan een baby. Er kunnen neurologische, musculaire (biomechanische) of optische redenen ter grondslag liggen. De balans tussen deze factoren is delicaat. De motorische en sensorische ontwikkeling van binoculariteit vindt tegelijkertijd plaats in deze eerste maanden. Door de oogbewegingen van baby"s te meten met behulp van het in hoofdstuk 6 beschreven videosysteem, kan de normale ontwikkeling van de binoculariteit vastgelegd worden. Deze informatie kan er wellicht toe leiden dat men in de toekomst eerder en effectiever kan ingrijpen bij een gestoorde ontwikkeling. 


\section{Dankwoord.}

"The been very lonely in my isolated lower of' indecipherable speed" (D). Lester in "Being John Malkowich'). Een promotieonderzoek doen als Gysicus in een ziekenhus valt niet altijd mee; voordat men de taal verstaat is het soms lastig communiceren. Als men vervolgens aan een onderwerp werkt waarin slechts een klein aantal mensen binnen het institut (en binnen Nederland) actief zijn, blijven de mogelijktheden beperkt om met verschillende mensen over het onderwerp van je promotie van gedachten te wisselen. Desahiettemin heb ik me de laatste 4 jaar prima vermalakt in het azM en is er een hele reeks mensen die ik hiervoor wil bedanken.

Ten eerste wil ik mijn co-promotor Marcel ten Tusscher bedanken voor zowel de begeleiding van het onderzoek als voor de prettige samenwerking die we de laatste jaren gehad hebben. Bimnen de KNO ten eerste Herman Kingma, die me op zijn gebrukelijke energieke manier enthousiasmeerde voor de westibulologie. Ten tweede Professor Manni, voor zijn inzet om, als KNO-arts, bij het doomemen van mijn artikelen telkens alle fysische en oogheelkundige aspecten te doorgronden. Professor Troost en professor Vhes van de afdeling Neurologie voor de begeleiding van de promotie en her corrigeren van de artikelen. Iwan voor de snelle hulp bij de welhaast continue aanpassingen wan de sofware en hardware van de verschillende opstellingen en woor menig avondje in de tuin onder het genot van zelfgemporteerde vin et saucisson. Joris als mede AlO voor de hulp (en steun) bij de totstandkonning van de promotic en voor alle barbecues. Vervolgens de overige stafleden en medewerkers van de KNO en de laborantes wan de evenwichtafdeling voor hum interesse en prettige werksfeer wan de afgelopen jaren. Alle (ex-) KNO assistenten med wie ik zowel tijdens als na het werk (wanneer is de volgend spelletjesavond?) een prima tijd heb gehad. De oude en nieuwe garde van het $\mathrm{KNO}$-secretariaat voor hun hulp, met narne bij de pogingen van het bijcenkrijgen van 4 professoren voor de regelmatige werkbesprekingen. Alle studenten en alstudeerders voor hun hulp bij het onderzoek. Tenslotte mijn vader, moeder (die zich bij elke nieuwe studie zich bezorgd afvroeg of ik het wel aankon), broers en schoonzussen, vrienden en natuurlijk Gerrie voor hun steun, interesse en nog veel meer. 


\section{Curriculum vitae.}

Jeroen Bosman werd geboren op 19 februari 1970 te Hengelo (O). Na 2 jaar HA VO op de Bataafsche Kamp te Hengelo (1982 - 1984) werd de overstap gemaki natar de MAVO Driener-Es te Hengelo (1984 - 1986). Na het diploma te hebben gehaald ging hij natur het Middelbaar Laboratorium Onderwijs (HTS/SVL) in Hengelo (1986 - 1989) alwaar hij voor het theoretisch gedeelte de certificaten behalde. Aangezien de chemie hem niet aansprak maakte hij vervolgens de overstap naar de HTS Toegepaste Natuurkunde op de Hogeschool Enschede. Hier werd het diploma gehaald in 1993. Vervolgens werd de opleiding Technische Naturkunde op de Technische Universiteit Eindhoven gevolgd van 1993 tot en met 1996. Het afstudeeronderzoek werd uitgevoerd in het Sint Joseph Ziekenhuis te Veldhoven, waar de interesse voor de klinische fysica werd opgewekl. Vervolgens werd in de periode $1997-200$ l. het promotie onderzoek uitgevoerd binnen het onderzocksinstituut Hersenen \& Gedrag van de Universiteit Maastricht in het Academisch Ziekenhuis Maastricht op de afdelingen KNO, Oogheelkunde en Neurologie. Momenteel is hij in opleiding tot algemeen klinisch fysicus in het Catharina Ziekenhuis te Eindhoven, hij hoopt deze (laatste?) opleiding in 2005 at te ronden. 